\title{
EFEITO DO GENÓTIPO E DA ÉPOCA DE SEMEADURA NA SANIDADE DE SEMENTES DE SOJA [qlyoine max (L.) MERRILL] NO ESTADO DE GOIÁS
}

\author{
JOSE NUNES JÜNIOR
}

Eng ${ }^{\circ}$ Agr ${ }^{\circ}-$ EMGOPA/GOIÁS

Orientador: Prof. Dr. JOSÉ OTÁVIO MACHADO MENTEN

Dissertação apresentada à Escola Superior de Agricultura "Luiz de Queiroz", da Universidade de São Paulo, para obtenção do título de Mestre em Agronomia. Área de Concentração: Fitopatologia.

PIRACICABA

Estado de São Paulo - Brasil

Junho - 1984 
ii.

Aos meus pais, irmãos, sogros $e$

cunhados,

MINHA HOMENAGEM

A minha esposa,

Maria Divina

$e$ aos meus filhos,

Larissa, Bruno e Lorena.

DEDICO. 


\section{AGRADECIMENTOS}

Desejo aqui consignar os meus agradecimentos às seguintes pessoas e entidades que tornarampos sível a realização deste trabalho:

A Empresa Goiana de Pesquisa Agropecuāria - EMGOPA,pe la oportunidade concedida para a realização do Curso de Mestrado;

A Empresa Brasileira de Pesquisa Agropecuária - EMBRAPA, pela concessão de bolsa de estudo durante. o referido curso;

Ao Prof. Dr. José Otávio Machado Menten, pelos esclare cimentos inestimáveis, lúcidas sugestões e que, com admirável dedicação, deu-me eficiente orientação;

Aos Professores: Eric Balmer, Paulo de Campos Torres de Carvalho, Hiroshi Kimati, Clélio Lima Salgado, Tasso Lêo Krugner, Armando Bergamin Filho e Luis Gonza ga Lorde11o, pelos ensinamentos;

Ao Centro de Processamento de Dados (CPD) do CENA/USP, pelos trabalhos referentes à análise estatística;

A Maria Izalina Ferreira Alves, pelos serviços datilo gräficos; 
Aos Engọ Agros Alberto Vasconcelos Costa e Renato Barbosa Rolim, pela minha iniciação na carreira de pes quis ador;

Aos Engọs Agrọs Renato Barbosa Rolim e Pedro Manoel de Oliveira Monteiro, pela colaboração na condução dos ensaios de campo;

Aos Técnicos Agrícolas João Batista Nunes Sobrinho e Fran cisco de Paulo Resende, pelo preparo das sementes para os testes de sanidade;

Aos Funcionärios do Departamento de Fitopatologia, péla extraordinäria dedicação e cortesia no atendimento, e pela colaboração valiosa durante os trabalhos experimentais;

A minha esposa, Maria Divina de Castro Nunes, pelo amor, estímulo e dedicação;

Ao Engo Agrọ Sérgio Bueno de Paiva, e ao Prof. Dr. Tasso Léo Krugner, pela versão do Resumo para o inglês;

Finalmente, mas não por ültimo, aos amigos e colegas do Curso de Pós-Graduação, pelo estímulo, ajuda e suges tões, especialmente aos Engọs-Agrọs Seiji Igarashi, Wagner Bettiol, Hilärio A. de Castro, Heloisa Duarte Moraes e Rosa Maria V. Sanhueza. 
1. INTRODUÇAO $\ldots \ldots \ldots \ldots \ldots \ldots \ldots \ldots \ldots \ldots \ldots$

2. REVISÃo de literatura $\ldots \ldots \ldots \ldots \ldots \ldots \ldots \ldots$

2.1 - Importância da Patologia de Sementes .. 4

2.2 - Métodos de Anälise de Sanidade de Semen

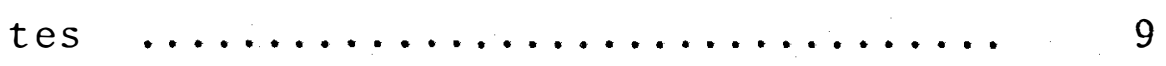

2.3 - Levantamento de Patógenos Associados a Sementes de Soja (Glycine max) ....... 15

2.4 - Importância dos Principais Patógenos As sociados a Sementes de Soja (Glycine max) 20

2.4 .1 - Seca da vagem e da haste .... 20

2.4 .2 - Antracnose da soja ........ 22

2.4.3 - Mancha pürpura da semente de so ja $\ldots \ldots \ldots \ldots \ldots \ldots \ldots \ldots . \ldots \ldots$

2.4 .4 - Podridão da vagem.......... 25

2.4.5 - Mancha de levedura das sementes 26

2.4 .6 - Mosaico comum da soja ...... 28

2.5 - Efeito do Genótipo na Incidência de Patógenos Associados às Sementes ...... 30

2.6 - Efeito da Epoca de Semeadura na Incidência de Patógenos Associados às Sementes ... 33

3. MATERIAL E METODOS $\ldots \ldots \ldots \ldots \ldots \ldots \ldots \ldots \ldots . \ldots \ldots$

3.1 - Local e Epoca de Realização da Pesquisa 36

3.2 - Experimentos de Campo ............ 37 
3.2.1 - Instalação e condução do exper $\underline{i}$ mento $\ldots \ldots \ldots \ldots \ldots \ldots \ldots \ldots$

3.2 .2 - Epocas de Semeadura................ 38

3.2.3 - Características botấnicas e agro nômicas das cultivares de soja utilizadas na pesquisa $\ldots \ldots .38$

3.2.4 - Delineamento experimental ... 41

3.2.5 - Avaliação das características agronômicas estudadas ....... 41

3.3 - Experimentos de Laboratório ........ 43

3.3.1 - Análise visual de sementes manchadas $\ldots \ldots \ldots \ldots \ldots \ldots \ldots$........ 43

3.3 .2 - Análise da sanidade de sementes de soja $\ldots \ldots \ldots \ldots \ldots \ldots \ldots$. 44

3.4 - Anälise estatística dos dados....... 45

4. RESUltados....................... 47

4.1. Efeito do Genótipo de Epoca de Semeadura na Incidência de Mancha Pưrpura em Sementes

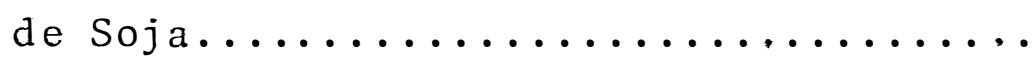

4.2. Efeito do Genótipo de Época de Semeadura na Incidência de Mancha Café em Sementes de Soja........................ 50

4.3. Efeito do Genótipo da Época de Semeadura na Incidência de Mancha de Levedura em Sementes de Soja.................. 
4.4 - Efeito do Genótipo e da Época de Semeadura na Detecção de Microrganismos Associados a Sementes de Soja Atravês do Mêtodo do Papel de Filtro, Com e Sèm Congelamento $\ldots \ldots \ldots \ldots \ldots \ldots \ldots \ldots \ldots \ldots$

4.5 - Efeito do Genótipo e da Epoca de Semeadura na Incidência de Phomopsis sojae em Se-

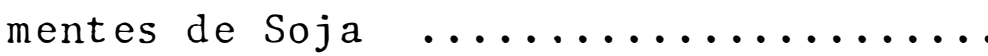

4.6 - Efeito do Genótipo e da Época de Semeadura na Incidência de Colzetotrichum dematium var. truncata em Sementes de Soja ...

4.7 - Efeito do Genótipo e da Epoca de Semeadura na Incidência de Cercospora kikuchii em Se

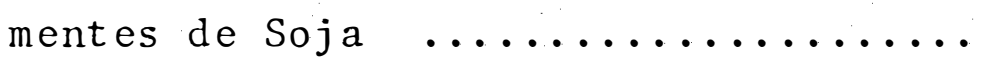

4.8 - Efeito do Genótipo da Época de Semeadura na Incidência de Fusarium semitectum em Se mentes de Soja $\ldots \ldots \ldots \ldots \ldots \ldots \ldots \ldots$

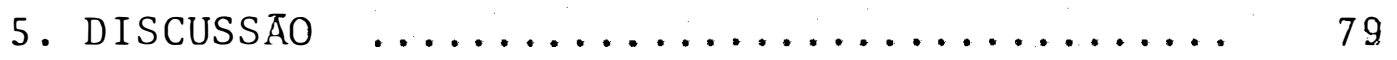

5.1 - Metodologia para Deteç̧ão de Microrganismos Associados a Sementes de Soja ..

5.2 - Efeito do Genótipo na Sanidade de Semen tes de Soja .................. 83

5.3 - Efeito da Época de Semeadura na Sanidade de Sementes de Soja...$\ldots \ldots \ldots \ldots \ldots .94$

6. CONClusóes $\ldots \ldots \ldots \ldots \ldots \ldots \ldots \ldots \ldots \ldots \ldots \ldots \ldots$

7. Literatura Citada $\ldots \ldots \ldots \ldots \ldots \ldots \ldots \ldots . .105$.

8. APENDICES $\ldots \ldots \ldots \ldots \ldots \ldots \ldots \ldots \ldots \ldots \ldots \ldots \ldots \ldots \ldots$ 
viii.

\section{EFEITO DO GENÓTIPO E DA ÉPOCA DE SEMEADURA NA SANIDADE DE SEMENTES DE SOJA [Glycine max (L.) MERRILL] NO ESTADO DE GOIÁS}

CANDIDATO: Josë Nunes Jünior

ORIENTADOR: Prof. Dr. José Otävio Machado Menten

\section{RESUMO}

0 presente trabalho foi realizado em con dições de campo e laboratório, empregando-se sementes de soja (Glycine max) produzidas no ano agrícola 1981/82, no Estado de Goiás; teve por objetivo estudar a época de semeadura e os genótipos mais adequados para a produ ção de sementes de soja com melhores condições de sanidade, comparar a metodologia mais adequada para a detec ção de patógenos associados às sementes e comparar os genótipos e época de semeadura quanto aos caracteres a gronômicos .

Utilizaram-se as cultivares Paraná, Bos sier, Santa Rosa, Tropica1, IAC-2, IAC-8, UFV-1, Numbai ra, IAC-7, Doko, IAC-6, EMGOPA-301, Cristalina e Parana goiana, em quatro épocas de semeadura: 21/10, 30/10, 
09/11 e 19/11 de 1981. O delineamento experimental usado foi o em blocos ao acaso, esquema fatorial $14 \times 4$ (14 cultivares e 4 épocas de semeadura), com 3 repetições.

A avaliação das caracterîsticas agronômi cas foi efetuada através dos seguintes parâmetros: rendimento, ciclo, acamamento, altura de plantas, altura da inserção da 1 ạ vagem e peso de 1000 sementes. A avaliação visual das sementes foi efetuada através dos seguintes parâmetros: mancha pürpura, mancha café e mancha de levedura. A avaliação da sanidade das sementes foi efetuada através do método do papel de filtro, com e sem congelamento, realizando-se a detecção e identífi cação dos microrganismos associados a sementes.

Foram detectados 20 espécies de fungos associados a sementes de soja: Phomopsis sojae, Colleto trichum dematium var. truncata, Cercospora kikuchii, cer cospora sojina, Fusarium semitectum, Macrophomina phaseolina, Phoma sp., Oreschslera sp., Alternaria tenuis, Penicillium spp., Aspergillus spp., Cladosporium sp., Paecilomyces sp., Pestalotia sp., Curvularia sp., Rhizo pus sp., Nigrospora sp., Epicoccum sp., Stemphylium sp., Chaetomium sp. Para comparação de métodos foi verificado que houve efeito do método de avaliação da sanidade na recuperação de microrganismos associados a sementes. O método do papel de filtro sem congelamento mostrou-se o mais adequado para avaliação da sanidade de semen 
tes de soja, por proporcionar melhor recuperação, detec ção e identificação dos microrganismos associados a sementes de soja. Bactérias não identificadas foram recuperadas em elevadas frequências através do método do pa pel de filtro com congelamento.

Foram detectadas diferenças significativas entre cultivares de soja ou épocas de semeadura quan to à incidência de microrganismos patogênicos à cultura (P. sojae, C. dematium var. truncata e F. semitectum) as sociados a sementes, sintomas nas sementes (mancha pürpura, mancha café e mancha de levedura), ou características agronômicas consideradas.

Os cultivares que mais se destacaram, par. ticularmente devido a condições de sanidade das sementes, foram Doko, Tropical e Cristalina. Analogamente, a época de semeadura que se destacou como a mais adequada para produção de sementes foi a de meados de novembro. Quanto aos caracteres agronômicos os cultivares que mais se destacaram foram Cristalina, Tropical, UFV-1, Parana goiana, Bossier e Doko. A terceira época de semeadura foi a que mais se destacou. 


\section{EFFECT OF GENOTYPE AND SEEDING TIME ON THE SOYBEAN [Glycine $\max (L$,$) MERRILL] SEED HEALTHY$ \\ IN THE STATE OF GOIÁS, BRAZIL.}

CANDIDATE: José Nunes Júnior

ADVISER: Prof. Dr. José Otävio Machado Menten

\section{SUMMARY}

The present study was carried out state of under field and laboratory conditions, utilizing seeds produced in state of Goiás, Brazil, during 1981/82; its objectives were to determine the best sowing date and the best genotypes for the production of soybean seeds with good sanitary conditions and to determine the best methodology to detect seed pathogens.

The cultivars utilized were Paraná, Bossier, Santa Rosa, Tropica1, IAC-2, IAC-8, UFV-1, Numbaira, IAC-7, Doko, IAC-6, EMGOPA-301, Cristalina and Paranagoiana at four dates of sowing; $10.21 ; 10.30 ; 11.9$ and 11.19 of 1981. The experimental design employed was the one in randomized blocks, factorial scheme $14 \times 4$ (14 cultivars and 4 dates of sowing), with 3 replications. 
The evaluation of the agronomic characteristics was done through the following parameters: yield, duration of the cicle, lodging and heigth of the plants, height of insertion of the $1^{\text {st. }}$ pod, weight of 1,000 seeds. The visual healthy evaluation of the seeds was done through the following parameters: purple stain, brown stain and yeast stain. The sanitary evaluation of the seeds with respect to the microrganisms associated, was carried out through the blotter method, with and without deep freezing.

Twenty species of fungi were detected:

Phomopsis sojae, Colletotrichum dematium var. truncata, Cercospora kikuchii, Cercospora sojina, Fusarium semitectum, Macrophomina phaseolina, Phoma sp., Dreschslera sp., Alternaria tenuis, Penicillium sp., Aspergillus sp., Cladosporium sp., Paecilomyces sp., Pestalotia sp., Rhizopus sp., Nigrospora sp., Epicoccum sp., Stemphylium sp., Chaetomium sp. Although no statistical analysis had been performed, it was detected an effect of the method employed to recover the microorganisms with the seeds. The blotter method without freezing was the most adequate for the evaluation of sanity of the seeds. Non identified bacteria were recovered in high frequency through the blotter method with freezing.

There were statistically significant .. differences among the soybean cultivars and sowing dates with respect to the incidence of pathogens ( $P$. sojae, $C$. dematium 
var. truncata and $F$. semitectum) associated with the seeds, symptomatology seeds (purple stain, brown stain and yeast stain), and the agronomic characteristics studied.

The best cultivars, specially with respect to the sanity of the seeds were Doko, Tropical and Cristalina. The best seeding time was the latest one (mid - november). With respect to the agronomic characters, the cultivars that best performed were: Cristalina, Tropica1, UFV-1, Paranagoiana, Bossier and Doko, and the best seeding time was the third one. 
1. INTRODUÇĀO

A cultura da soja [Glycine max (L.) Merrill] vem ocupando uma posição de crescente destaque en tre os produtos agrícolas que atualmente alimentam os povos, considerando-se sua recente introdução na agricultura dos países do Ocidente como cultivo para a produção de grãos. A produção mundial, para a safra 1983/ 84, está estimada em 77,5 milhões de toneladas, $19 \%$ inferior à do período anterior. A produção brasileira de soja, para a safra 1983/84, deve situar-se em torno de 16,4 milhões de toneladas, ocupando uma ärea de9.092.893 hectares, $12,34 \%$ superior à safra do ano anterior, segundo informações do IBGE/CEPAGRo, através do Prognóstí co da Produção Agrícola, outubro/1983. Para o Estado de Goiās, a produção de soja para a safra 1983/84 está estimada em 822,5 mil toneladas, para uma ärea plantada 
e/ou a plantar de $470 \mathrm{mil}$ hectares (IBGE/GCEA/GOIÁS).

A introdução da soja em novas áreas, a intensificação de sua produção em ärea tradicionais e a adoção de certas técnicas de cultivo podem favorecer o estabelecimento de novas associações com outras espécies de patógenos (YORINORI, 1982). O uso de sementes não certificadas, procedentes de outros Estados ou Países, e de cultivares não testadas na região, podem ocasionar a introdução de novos patógenos ou patótipos de patógenos ainda não existentes. Um dos requisitos bảsicos para se obter uma população de plantas ideal para o cultivo da soja, segundo POPINIGIS (1975), é a qualidade da semente, que pode ser analisada sob os aspectos genéticos, fí sicos, fisiológicos e sanitários. O aspecto sanitärio compreende um conjunto de medidas que visam impedir ou diminuir a associação das sementes com os microrganis mos. Uma das medidas atualmente muito usada é o tratamento de sementes com fungicidas (ROSSEAU, 1977). Entretanto, diversas outras medidas como, o uso de cultivares resistentes, diversas práticas culturais e o prin cípio da evasão (táticas de fuga) podem ser utilizadas ví sando obter sementes de melhor qualidade, particularmen te quanto à sanidade.

Considerando que existem disponíveis diversas cultivares de soja, que podem ser semeadas em vá rias épocas do ano, è necessário que se determine os ge 
nótipos de soja e a época de semeada mais adequados para a produção de sementes com melhores condições de sanidade. Entretanto, os fatores cultivar e. época de semeadura também afetam as características agronômicas da soja. Cultivares de soja podem apresentar diferentes ní veis de resistência a microrganismos, tanto considerando a planta como um todo quanto considerando particular mente suas sementes.

As sementes de soja, dado às suas características morfolögicas e químicas, mostram-se muito sensiveis à ação dos fatores do ambiente que podem contribuir para a diminuição do poder germinativo e do vigor destas (MARCOS FILHO, 1979). Estes fatores ambientais em determinadas condições, podem tambëm afetar as carac terísticas físicas, químicas e sanitarias das. sementes (NAKAGAWA, 1981). Desta maneira, as condições de alta temperatura e alta umidade, durante o estádio final de maturação das sementes, são desfavoräveis a produção de sementes de soja de alta qualidade (PASCHAL II e ELLIS, 1978). Através da escolha da melhor época de semeadura em uma região, pode tentar-se ajustar as melhores condições climáticas para determinadas fases de crescimento e desenvolvimento das plantas; visando a obtenção de sementes de melhor qualidade.

Considerando que a produção de sementes de soja com sanidade satisfatöria é essencial para o desen 
volvimento de uma agricultura racional no Estado de Goiās, o presente trabalho teve como objetivos:

a. comparar os genótipos de soja para a pro dução de sementes com melhores condições de sanidade;

b. comparar épocas de semeadura para a produção de sementes com melhores condições de sanidade;

c. comparar as metodologias para a detecção de microrganismos associados às sementes de soja;

d. comparar os genótipos e ëpoca de semeadu ra quanto aos caracteres agronômicos. 
A patologia de sementes, de acordo com NEERGAARD (1979), é o estudo das doenças de sementes e das doenças cujos patógenos são por elas transmitidos. A importância desse estudo se deve ao fato de ser a semente veículo de agentes patogênicos que nela podem se alojar e com elas serem levadas ao campo, dando origem a focos de infecção primária de doenças ou afetando a qualidade da semente (germinação, vigor, etc.). Segundo SINCLAIR (1979), as populações de sementes de soja têm o potencial de transportar uma grande variedade de microrganismos, incluindo fungos, bactërias e virus, muitos dos quais causam doenças nas plantas. 
De acordo com NEEGAARD (1977), a' importância da semente como meio de transmissão de doenças, quando comparada a outros meios (vento, água, restos de culturas, solo, etc.), se deve a diversos fatores: (a) as sementes permanecem viäveis por mais longo tempo do que os propágulos vegetativos, prolongando o período po tencial de transmissão dos patógenos e estes permanecem viáveis por tempo mais longo em associação com o hospedeiro do que separadamente ou no solo. Além disso, o pa rasita está em íntima associacão com o hospedeiro no ca so de infecção de sementes, sendo que esta intima associação em espaço e tempo propicia oportunidade máximade infecção da progênie; (b) o inöculo da semente favorece a possibilidade de infecção mais precoce das plântulas; (c) solos livres de patógenos podem ser inoculados por sementes associadas a microrganismos e culturas sub sequentes estabelecidas a partir de sementes sadias podem ser infectadas através do solo; (d) a semeadura de sementes associadas a microrganismos determina a introdução de numerosos focos de infecção primária no campo, que é mais efetivo do que a infecção que vem depois das plantas já estabelecidas; (e) novos patótipos podem ser introduzidos através da semente. 
A semente tem sido a causa da disseminação de inümeros organismos fitopatogênicos no mundo, gra ças ao seu intenso comércio. Muitos exemplos podem ser citados de doenças que foram introduzidas em um país ou região através da semente (NEERGAARD, 1979). No caso da cultura da soja, a bactéria causadora do crestamento, Pseudomonas glycines, foi introduzida na Escöcia, em 1940, veiculada por sementes importadas da Suécia. A re cente introdução de sementes de soja brasileira infecta das pelo fungo Cercospora sojina, na Costa do Marfim, ocasionou uma epifitia da doença "olho-de-rã" (Kueneman, 1982 , citado por YORINORI, 1982). A ocorrência da mesma doença no Brasil Central (Distrito Federal, Goiäs, Minas Gerais e Mato Grosso do Sul), causando elevadas per das, foi devido à introdução de sementes infectadas (Yo RINORI , 1982).

A importância de microrganismos afetando a germinação e vigor das sementes tem sido pouco pesqui sada; porém, jả è conhecida a frequência destes microrganismos associados às sementes das diferentes espécies cultivadas. Pesquisas sobre danos causados por patôgenos de sementes são de grande necessidade para o estabe lecimento de padrões de sanidade (tolerânciàs). De acor do com NEERGAARD (1977), pouco se tem estudado sobre o assunto e apenas para um número reduzido de microrganis 
mos foi estabelecida a relação dos prejuízos com o grau de infecção das sementes. Segundo PASCHAL II e ELLIS (1979), patógenos transmitidos internamente pela semente têm sido mencionados como causadores da redução na germinação, vigor e emergência no campo, em culturas de soja e feijão.

Segundo NEERGAARD (1977), a semente è um dos veículos mais eficientes na disseminação de patógenos, devido a diversos fatores como: (a) são unidades pe quenas e fäceis de manusear, sendo facilmente transportadas atravês dos continentes; sua aparência sadia não revela os patógenos que podem conter; (b) podem hospedar patógenos de grande longevidade e em tão baixos níveis de incidência que não são revelados por amostragem; (c) na determinação de certos patógenos de sementes são utilizados testes de laboratório que requerem certas con dições e pessoal qualificado, ainda não disponíveis em muitos países. Devido a estes fatores, uma das medidas de controle usada para evitar a entrada ou saída de patógenos de uma região para outra è a quarentena, que $\vec{e}$ regida através de uma legislação, atuando no controlede pré e pós-entrada da semente. De acordo com WARWICK(1982), existem 25 patógenos da cultura da soja cuja ooorrência ainda não foi registrada no Brasil; estes patógenos são: 
Aecidium glycines, Alternaria alternata, Ascochyta sojae, Ascochyta sojaecola, Dactuliophora glycines, Erysiphe glycines, Melanospsichium missouriense, Mycosphae rella cruenta, Mycosphaerella phaeolorum, MycosphaerelIa sojae, Phialophora gregata, Phyllosticta glycines, Phyllosticta sojaecola, Pyrenochaeta glycines, Septogloeum sojae, Septoria sojina, Sphaceloma glycines, Syㅡ chytrium dolichi, Synchytrium umbilicatum, Uromyces sojae, Beet curly top virus, Bean pot mottle virus, soybean dwarf virus, soybean mottiing virus e soybean stunt mott le virus. São relatados alguns exemplos do sucesso de medidas de quarentena em diversos países. No Brasil, a doença conhecida como bakanae em arroz, causado por $F \underline{u}$ sarium moliniforme, foi erradicada da região do Vale do Paraíba, Estado de São Paulo, depois de ter sido a área deixada em quarentena por 5 anos (NEERGAARD, 1977). Segundo LAMBAT et alii (1969), o laboratório do Instituto de Pesquisa de Nova Delhi interceptou o fungo Colletotrichum dematium, agente causal da antracnose da soja, associado às sementes provenientes de Formosa. Esses exem plos mostram a importância da patologia de sementes, con tribuindo para a não disseminação de patógenos, atuando no controle de doenças pela exclusão. 
Segnndo NEERGAARD (1979), em patologia de sementes são definidas algumas äreas problemas tais como: os mecanismos de transmissão de patógenos, envolven do as condições e meios de estabelecimento e perpetuação das doenças transmitidas por sementes; o desenvolvi mento de métodos para detecção de fungos, bactērias, ne matöides e virus associados às sementes; a epidemiologia de patógenos transmitidos por sementes e, em particular, a importância relativa do inóculo originärio da semente, comparado com outros meios de disseminação, a fim de fornecer bases para avaỉiação de inóculo transmi tido pela semente; e a tecnologia do controle direto e indireto de patógenos transmitidos por sementes.

2.2 - Métodos de Anâlise de Sanidade de Sementes

O teste de sanidade de sementes è um tipo de "medicina preventiva" A atenção à sanidade da se mente às vezes pode assegurar o controle de uma doença, e muitas vezes aliviar a pressão sobre programas de me1horamento de plantas (HEWETT, 1979). Segundo NEERGAARD (1977), atè o momento, os métodos melhor desenvolvidos em laboratório são para detectar fungos patogênicos. No caso de bactérias e virus, os métodos são parcialmente 
desenvolvidos, usando-se, em geral, o teste em casa-de-vegetação, onde se pode observar sintomas nas plantas obtidas de sementes a serem testadas. Os principais métodos utilizados em patologia de sementes (MUSKETT e MA LONE, 1941; TEMPE, 1961, 1962, 1963, 1964; NOBLE, 1965; ANSELME et alii, 1966; LIMONARD, 1966, 1967, 1976; NATH et alii, 1970; LEACH, 1971; KULIK, 1973; NEERGAARD,1973; PHATAK, 1974 ; KULSHRESTHA et alii, 1976; KHARE et alii, 1977 ; NEERGAARD, 1977; LASCA, 1978; MENTEN, 1978 e YORI NORI et alii, 1979), são:

(a) Inspeção direta das sementes: observa-se as se mentes a olho desarmado ou sob o microscópio estereoscó pico, para a detecção de matéria inerte, escleröcios, man chas, mã formação das sementes e frutificação de fungos na superfície. Algumas doenças podem ser detectadas por esse método, tais como, virus do mosaico comum em soja, mancha pürpura da soja, ergot em gramineas, etc.;

(b) Método de sedimentação: toma-se certa quantida de de sementes, coloca-se em água destilada, com ou sem espalhante, agita-se por cerca de 10 minutos. A suspensão obtida e distribuída em tubos para centrifugação por 15 a 20 minutos a $2.500 \mathrm{rpm}$. Decanta-se o excesso da sus pensão, deixando-se uma quantidade mínima de $2 \mathrm{~cm}^{3}$, que é colocado em lâminas e examinada ao microscópio compos 
to, para observar a presença de esporos de fungos;

(c) Método do papel de filtro: as sementes são colocadas em placas de Petri de plástico, contendo discos de papel de filtro previamente embebidas em ägua, e incubadas à temperatura de $20^{\circ} \mathrm{C} \pm 2{ }^{\circ} \mathrm{C}$ durante $7-8$ dias, sob ciclos alternados de 1 uz e escuro de 12 horas.Atual mente se utiliza a luz próximo ao ultra-violeta (NUV) que, conforme LEACH (1979a) e TEMPE (1979), estimula a esporulação em diversos fungos. Após esse período de in cubação, as sementes são examinadas sob um microscópio estereoscópico para detecção dos fungos presentes; a maioria dos fungos imperfeitos podem ser detectados por esse método;

(d) Método do papel de filtro modificado com 2,4D: segue-se o mesmo procedimento descrito no método anterior, embebendo-se, porêm, as folhas de papel de filtro em solução de 2,4-D a 2 por mil, para que a germinação seja suprimida;

(e) Método do congelamento: também é uma modificação do método do papel de filtro. As sementes são distribuidas em placas e colocadas a $20^{\circ} \mathrm{C}$ por 1 a 4 dias ou $10^{\circ} \mathrm{C}$ por 3 dias e $20^{\circ} \mathrm{C}$ por 2 dias. Depois desse período são colocadas por 24 horas a $-20^{\circ} \mathrm{C}$ e voltam novamente à temperatura de $20^{\circ} \mathrm{C}$, até completar 7 ou 8 dias 
de incubação. Quando passam pelo menos 24 horas a $20^{\circ} \mathrm{C}$ antes do congelamento, hä a supressão da germinação e a avaliação é facilitada;

(f) Método do plaqueamento em ágar: distribuem-se as sementes em placa de Petri contendo meio de cultura agarizado (por exemplo, batata-dextrose-ágar), após a assepsia superficial com hipoclorito de sódio a $1 \%$. A incubação é feita durante 7 dias, em temperaturas em ge ral entre $20^{\circ} \mathrm{C}$ e $28^{\circ} \mathrm{C}$, de acordo com a cultura; a detec ção e identificação dos fungos é feita com base nas características das colônias;

(g) Método de contagem de embriões: é utilizado pa ra determinar infecção de carvão de trigo e de cevada causados por Ustilago tritici e Ustilago nuda, que se localizam no embrião das sementes. Cerca de 2.000 semen tes são colocadas numa solução de $\mathrm{NaOH}$ a $10^{\circ}$ e conserva da à temperatura de $22^{\circ} \mathrm{C}$ por uma noite. As sementes são agitadas com água quente e passadas em peneiras para se paração dos embriões. Os embriões são então transferidos para um becker, o excesso de água é retirado e adicionado lacto-fenol. Depois de clareados por aquecimento lento em banho maria, os embriões são examinados sob o microscópio estereoscôpico para se observar a presença do fungo no escutelo; 
(h) Método do papel toalha: é semelhante ao usado para teste de germinação. As sementes são distribuídas em folhas de papel toalha, depois de realizada a assepsia superficial com hipoclorito de sódio a $1 \%$. 0 papel $\vec{e}$ enrolado e a incubação e feita a $20^{\circ} \mathrm{C} \pm 2{ }^{\circ} \mathrm{C}$, com umidade próxima à saturação. Depois de 7-8 dias é feita a avaliação de sintomas nas plântulas. E indicado para de tectar infecção de colletotrichum lindemuthianum em sementes de feijão;

(i) Método geral para deteç̧ão de bactérias: as se mentes, após assepsia superficial com $\mathrm{HgCl}_{2}$ por 3 a 5 minutos, são lavadas com ảgua esterilizada. Trituram-se as sementes com $15 \mathrm{~cm}^{3}$ de água destilada esterilizada; com uma alça de platina tomam-se gotas para fazer estrias em meio sólido para bactẹrias. A incubação è feïta durante 5 a 7 dias, a $25^{\circ} \mathrm{C}$ a $28^{\circ} \mathrm{C}$. As bactérias desenvolvem colônias que devem ser identificadas através de testes bioquímicos ou de patogenicidade;

(j) Teste de crescimento: distribuem-se sementes a se rem testadas em solo livre de patógenos e observam-seos sintomas durante o ciclo das plantas obtidas. E um méto do muito usado para deteç̧ão de bactérias e virus. Obtêm-se informações mais próximas das condições de campo. Outros substratos podem ser usados para germinação de 
sementes e observação de sintomas nas plântulas: areia, vermiculita, ägar-ägua, etc. Testes em plantas indicado ras, serologia, uso de fagos, etc., são técnicas também usadas na detecção e identificação de vírus e bactérias em sementes.

Segundo NEERGAARD (1977), o método do pạ pel de filtro è amplamente usado onde testes regulares de sanidade são efetuados. O método pode ser designado como um híbrido entre o método da câmara ümida, usado em patologia vegetal, e o teste de germinação, usado em tecnologia de sementes, combinando as vantagens de pesquisas in vitro com observações in vivo. Muitos fungos patogênicos transmitidos pelas sementes podem ser detec tados pelo método do papel de filtro e pelo método do ägar (LEACH, 1979). Entretanto, SINCLAIR e DHINGRA(1975), comparando ambos, verificaram que o primeiro se comportou melhor na recuperação dos patógenos associados às sementes de soja. Na maioria dos casos, para a recupera ção de patögenos associados às sementes de soja, é utilizado o método do papel de filtro modificado com a adi ção de 2,4-D, para suprimir a germinação das sementes (SINCLAIR e DHINGRA, 1975 ; SONEGO e BOLKAN, 1978; ANTEPARA et alii, 1979 e DHINGRA et alii, 1979). 
E tambëm bastante utilizado, na identifi cação de microrganismos associados às sementes de soja, o método do ágar. Vârios são os relatos a respeito do em prego de meios de cultura, principalmente batata-dextro se-ágar (BDA), na identificação de patógenos que infeç tam as sementes de soja, conforme MURAKISHI (1951), KI $\underline{L}$ PATRICK e HARTIWIG (1955), CHARBERLAIN e GRAY (1974),EL LIS et alii(1974), FOOR et alii (1976), FULCO et alii (1979), MCGEE e BRANDT (1979), YORINORI et alii (1979) e HEPPERIY e SINCLAIR (1980).

2.3 - Levantamento de Patógenos Associados a Sementes de Soja (Grycine max)

Segundo NEERGAARD (1977), na família Leguminosae as doenças cujos patógenos são transmitidos por sementes são mais frequentes e severas do que em qualquer outra familia. A cultura da soja $\vec{e}$ infectada por mais de 100 patógenos, dos quais, de acordo com SIN CLAIR e SHURTLEFF (1975) e SINCLAIR (1980), cerca de 35 são economicamente importantes.

Os principais patógenos associados às se mentes de soja, segundo NOBLE e RICHARDSON (1968), COMPENDI UM OF SOYBEAN DISEASES (1975); RICHARDSON (1979) e RICHARDSON (1981), são: 
- Phomopsis sojae+

- Cercospora kikuchii +

- Peronospora manshurica +

- Colzetotrichum dematium var.truncata+

- Fusarium spp. +

- Macrophomina phaseolina +

- Myrothecium roridum +

- Aspergizzus sp.

- Rhizoctonia solani +

- Alternaria spp.

- Ascochyta sojaecola

- Cephalosporium gregata

- Cercospora sojina+

- Chaetomium sp.

- Chaetophoma sp.

- Cradosporium sp.

- Corynespora cassicoza +

- Curvularia Zunata

- Dreschslera tetramera

- Epicoccum purpurascens

- Glomerelza glycines

- Macrophoma mame

- He Iminthosporium sp.

- Melanopsichium missouriense 
- Monilia sp.

- Nigrospora oryzae

- Penicillium sp.

- Pestalotia sp.

- Phialophora gregata

- Phoma sp.

- Phyllosticta sp.

- Pleosphaerulina sojicola

- Phytophthora megasperma

- Rhizopus nigricans

- sclerotinia sclerotiorum +

- Sclerotium rolfsii +

- Septoria glycines +

- Stemphylium sp.

- Thielaviopsis basicola

- Verticicillium sp.

- Rhizoctonia leguminicola

- Toruza spp.

- Pseudomonas solanacearum +

- Pseudomonas glycines +

- Pseudomonas tabaci +

- Xanthomonas, glycines +

- Corynebacterium flaccunfaciens

- Corynebacterium sp. 
- Bacillus subtilis +

- "Alfafa mosaic virus"

- "Arabis churry leaf rood virus"

- "Cowpea mild mottle virus"

- "Soybean stunt mottle virus"

- "Tobacco ringspot virus"

- "Tobacco treak virus"

- "Tomato black ring virus"

- "Tomato ringspot virus"

- "Soybean mosaic virus" +

- Heterodera glycines +

Os patógenos identificados (+) causam doen ças de importância econômica à cultura.

Em levantamento feito no Estado de São Paulo foram observados, associados às sementes de soja, os seguintes microrganismos, de acordo com ITO et alii (1981): Alternaria cheiranthi; Alternaria spp.; Aspergillus spp.; Botryodiplodia theobromae; Cephalosporium spp.; Chaetomium spp.; Cladosporium spp.; Colletotrichum sp.; Colletotrichum truncatum; Corynespora: cassicola; Curvularia brachyspora; Curvularia Iunata; Curvularia protuberata; Diaporthe phaseolorum var.sojae; Drechsle rasp.; Epicoccum spp.; Fusariella sp.; Fusariella indi 
ca; Fusarium aquaductum; Fusarium concolor; Fusarium cuI morum; Fusarium dimerum; Fusarium equiseti; Fusarium fu sarioides; Fusarium Zarvarum; Fusarium lateritium; Fusarium lateritium var. buxi; Fusarium moniliforme; Fusarium oxysporum; Fusarium poae; Fusarium sambucinum; Fusarium solani; Fusarium semitectum; Fusarium sulphureum; Fusarium ventricorum; Fusarium xylarioides; Gonatobotryum sp.; Graphium sp.; Helminthosporium spp.; Mucor spp.; Myrothecium spp.; Nigrospora spp.; Papularia sp.; Penicillium spp.; Periconia spp.; Pestalotia spp.; Phoma sp.; Pheoastoma sp.; Phomopsis sojae; Pitomyces spp.; Pitomyces chartarum; Pitomyces maydicus; Pitomyces sacchari; Pythium spp.; Rhizoctonia spp.; "Rhizopus spp.; Sclerotium bataticola; Sporocybe sp.; Torula spp.; Thie Zaviopsis sp.; Trichoderma spp.; Verticillium spp.; Tri chothecium roseum. Trabalhos semelhantes foram feitos no Distrito Federal por BOLKAN e CUPERTINO (1976); no Rio Grande do SuI por LEHMAN et alii (1976); no Paranä por HOMECHIN et alii (1977) e no Mato Grosso do Sul por SONEGO e BOLKAN (1978); entretanto, foram considerados somente os microrganismos patogênicos à cultura da soja. 
2.4 - Importâncịa dos Principais Patógenos Associados a Sementes de Soja (Glycine max)

A redução da qualidade e poder germinatí vo da semente de soja pode estar associado a sementes en rugadas, fendidas, esmagadas, mofadas, imaturas, prejudicadas pelas intempéries, trilha, beneficiamento e armazenagem inadequada. Entretanto, grande parte desta re dução é causada por patógenos que atacam as sementes en fraquecidas por ocasião da germinação (FULCo, 1977).

\subsection{1 - Seca da vagem e da haste}

A seca da vagem e da haste da soja tem como agente causal o fungo Phomopsis sojae Lehman [Diaporthe phaseolorum var. sojae (Leh.) Wehm.]. Atualmente è uma molẻstia muito comum, e possivelmente a principal causa do apodrecimento das sementes de soja (CARDOSO, 1980 e YORINORI, 1982). Na fase vegetativa da planta, o fungo normalmente fica associado, de forma sistêmica, com os tecidos superficiais da haste, pecíolo, flor e vagem, podendo infectar os grãos, desde o estädio inicial de formação (KMETZ et alii, 1974). Sua importância está crescendo gradativamente devido à perda de qualida de de sementes de soja, refletindo no tamanho e aparên- 
cia da semente, além de influir no poder germinativo, viabilidade e vigor (FERREIRA, 1973; SINCLAIR, 1978; HENNING e FRANÇA NETO, 1980).

Foi observado, por ELLIS et alii (1972), uma redução na germinação e emergência no campo, quando a percentagem de sementes infectadas eram de $25 \%$ oumais. A baixa qualidade em sementes de soja infectadas por Pho mopsis sojae é citado tambëm por WALLEN e CUDDY (1960), WALLEN E SEAMAN (1962), PETERSON e STRELECKI (1965), NICHOLSON et alii (1972), CHAMBERLAIN e GRAY (1974), TENNE et alii (1974), WILCOX et alii (1974), BOLKAN e CUPERTINO (1976), FOOR et alii (1976), RODRIGUES-MARCANO e SINCLAIR (1978), KMETz et alii (1978), ELLIS et alii (1979), HEPPERLY e SINCLAIR (1980) e KULIK e SHOEN (1981).

Condições de ambiente com altos indices de temperatura e umidade relativa, devido à ocorrência de chuvas durante a fase de maturação, são condições ideais para formação e disseminação dos esporos de Phomopsis sojae (FERREIRA, 1973; WILCOX et alii, 1974; TEDIA, 1976; HENNING e FRANÇA NETO, 1980; SINCLAIR, 1980; SHORT et alii, 1981; SPILKER et alii, 1981; TEKRONY et alii, 1983). 


\subsection{2 - Antracnose da soja}

E causado pelo fungo Colletotrichum dema tium var. truneata (Schw.) Andrus e Moore. Segundo YORI NORI (1982), a moléstia está presente em todas as lavou ras de soja, porẻm, até o momento não tem se constituído problema sério para a cultura. O agente causal da an tracnose da soja infecta a planta em todos os estádios de crescimento. As sementes infectadas podem morrer no solo, ou quando emergirem apresentam os cotilëdones deteriorados, os quais servem como fonte primâria de inóculo.

Os danos ocasionados pela antracnose da soja foram primeiramente descritos por LEHMAN e WOLF (1926), que consideraram uma doença de haste e vagens. Posteriormente, vârios pesquisadores observaram a impor tância de Colzetotrichum dematium var. truncata como agente de tombamento de pré e pós-emergência e crestamen to de plântulas (LING, 1940; TIFFANY, 1951; SCHNEIDER et alii, 1974; RODRIGUES-MARCANO e SINCLAIR, 1978; ELLIS et alii, 1979). Diferentes frequências de Colletotrichum dematium var. truncata associados a semente de soja foram detectadas por KILPATRICK e HARTWIG (1955), FRENHANI (1969) e DHINGRA e SILVA (1978), porēm, estas fre- 
quências não foram relacionadas com a incidência da doen ça no campo.

Condições de ambiente como altos indices de temperatura e umidade relativa, na ëpoca de maturação das vagens, favorecem um melhor desenvolvimento do agente causa da antracnose da soja (MARTYN, 1942 e YORI NORI, 1982). A importância do ambiente tambëm é relatado por SINCLAIR e SHURTLEFF (1975), comentando que a frequência de colletotrichum dematium var. truncata depende também da época de plantio e do local; citam ainda que nas regiões tropicais e subtropicais a ocorrência é maior. Para FERREIRA (1973), CARDOSO (1980) e YORINORI (1982), o agente causal da antracnose da soja sobrevive no campo em restos da cultura e è facilmente transmitido através de sementes infectadas.

2.4.3 - Mancha pürpura da semente de soja

A mancha pürpura das sementes de sojatem sido bastante estudada quanto a seu efeito na qualidade e transmissão do agente causal da doença. E causada pelo fungo Cercospora kikuchii (Matsumoto e Tomoyasu) Gardner e, segundo YORINORI (1982), sua importância cres ce a cada ano devido a sua ocorrência generalizada. Entretanto, aparentemente não chega a causar prejuízos à 
cultura, mas confere um aspecto desagradảvel às sementes, abrindo vias para infecção de outros agentes patogênicos.

De acordo com MURAKISHI (1951) e WILCOX e ABNEY (1973), a germinação foi, respectivamente, 19\% e $5 \%$ menor em sementes com mancha pürpura que nas semen tes sem manchas. Com relação à emergência no campo foram de 7 a $15 \%$ menor nas sementes com manchas pürpura (WILCOX e ABNEY, 1973). Foi observado por NUNES Jr. e MENTEN (1984) que sementes com mancha púrpura tiveram sua qualidade reduzida na germinação em $3,1 \%$ após a co1heita e em 12,8\% apös oito meses de armazenamento. A redução na qualidade de sementes de soja por mancha pự pura ë citado também por diversos autores, como MURAKISHI (1951), KILPATRICK e HARTWIG (1955), DIAZ-POLANCO (1966), GOMES (1975), BERNAUX (1976), CHEN et alii (1979), HEPPERLY e SINCLAIR (1981), FRANÇA NETO et alii (1983), LUCCA FILHO e CASELA (1983) e YORINORI e SINCLAIR(1983).

As condições de ambiente, principalmente altos indices de umidade relativa, devido a chuvas ocorrendo no período de maturação, são condições ideais para aumentar a incidência da mancha púrpura, segundo SUZUKI (1921), MATSUMOTO e TOMOYASU (1922), MURAKISHI (1951), LAVIOLETTE e ATHOW (1972), REIS (1975), CHEN et alii (1979) e YORINORI (1982). 
O agente causal da mancha pürpura sobrevive no solo, em restos de cultura e sementes (KILPATRI CK, 1951, 1957; JONES, 1968; LEHMAN, 1952 e YORINORI, 1982). Sua disseminação se dá através dos restos de cul tura e das sementes infectadas (MATSUMOTO e TOMOYASU, 1922 ; KILPATRICK , 1951，1953，1957; YORINORI , 1982;FRAN CCA NETO et alii, 1983; LUCCA FILHO e CASELA, 1983 e NUNES Jr. e MENTEN, 1984).

\subsection{4 - Podridão da vagem}

Segundo BOLKAN et alii (1976), DHINGRA e SILVA (1978) e DHINGRA et alii (1978), os patógenos Pho mopsis sojae e Fusarium semitectum Berk. e Rav. são os principais agentes responsảveis pela deterioração de se mentes de soja no Brasil, implicando na sua mả qualidade. Foi observado por HEPPERLY e SINCLAIR (1981), que os fungos isolados de sementes de soja, em Porto Rico, que apresentaram maior frequência foram: Phomopsis sojae, Cercospora kikuchii e Fusarium spp. (principalmente F. semitectum). De acordo com CHAGAS e DHINGRA (1979), e DHINGRA (1978), sementes de feijão produzidas em Minas Gerais e em outras partes do Brasil têm a germinaçãobai xa, devido a infecção das sementes por $F$. semitectum. 
Conforme DHINGRA et a $i$ i (1978), F. sem $\underline{i}$ tectum infecta as sementes de soja e feijão, penetrando atravës das vagens não injuriadas; consequentemente, as sementes não germinam. Avaliando o efeito de época de plantio na incidência de $F$. semitectum, foi observado

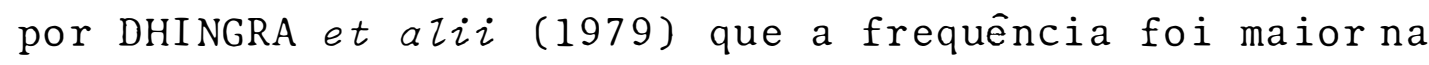
época normal de plantio, que em plantio tardio. Segundo DHINGRA e MUCHOVEJ (1979), F. semitectum causa podridão tanto na vagem como na raiz da soja.

2.4.5 - Mancha de levedura das sementes

Há cerca de um século são conhecidas leveduras parasitas de frutos e sementes; ocorrem sobre uma ampla gama de plantas cultivadas causando "estigmatomicose", "mancha ocular" e "podridão interna". Estes patógenos representam uma unidade filogenética reunida na família Nematosporaceae, que consiste em cinco gêneros: Ashbya, Eremothecium, Metschnikowia, Nematospora e Coccidiascus. A maioria das doenças està associada com puncturas feitas por insetos de aparato bucal picador-sugador e muitas espécies são fitopatógenos destrutivos (BATRA, 1973). Mancha de levedura em sementes de so ja foi relatada pela primeira vez nos Estados Unidos da 
América, simultaneamente por LEHMAN (1943) e FRESTON e RAY (1943). No Brasil, a primeira referência de nematos poräceas fitopatogênicas foi feita por KRUG (1937), relatando $N$. coryzi e N. gossypii em algodoeiro e N. cory Zi em caupi; em sementes de feijão comum ( $P$. vulgaris L.), GALLI et alii (1963), e em sementes de soja (Glyci ne $m a x$ ), HEINRICHS et alii (1976).

Estas leveduras, transmitidas por diversos vetores pertencentes principalmente às famílias Coreidae, Lygaedae, Miridae, Pentatomidae e Pyrrhocorridae (KRUG, 1937; LEACH e CLULO, 1943; DAUGHERTY, 1967; PARADELA Fọ et alii, 1968 e BATRA, 1973), são parasitas de ampla gama de hospedeiros pertencentes a familias bastante distintas (PEGLION, 1901; NOWELL, 1918; WINGARD, 1922; KRUG, 1937; KIMATI e NINOMYA, 1964 e BATRA, 1973).

Trabalhos em patologia de sementes de fei jão (ELLIS et alii, 1976, 1977; LASCA, 1978) e em semen tes de soja (HEINRICHS et a $i i i, 1976$ ) não tem relatado a ocorrência dos agentes causais da mancha de levedura; entretanto, MENTEN et alii (1979) observaram a presença de $N$. coryzi em sementes de feijão com mancha de levedu ra, através do método do ägar; por outro 1ado, NOBLE e RICHARDSON (1968), RICHARDSON (1979, 1981) referem Nema tospora spp. como um invasor de sementes picadas por in 
setos e não como um patógeno transmitido por semente. En tretanto, COSTA (1972) incluiu a mancha de levedura entre as doenças de maior importância do feijoeiro; têm sido relatadas sementes de feijão (MENTEN et alii, 1977; TAKATSU et alii, 1976 e KIMATI e NINOMYIA, 1964) e soja (HEINRICHS, 1976) afetadas por Nematospora spp..

$$
\text { 2.4.6 - Mosaico comum da soja }
$$

O mosaico comum è causado pelo virus do mosaico comum da soja (Soybean mosaic virus - SMV). Segundo YORINORI (1982), encontra-se praticamente presente em todas as lavouras do país. Relata ainda que, ate o momento, não foram constatadas reduções na produtividade devido a essa virose; porẹm, conforme GARDNER e KEN DRICK (1921), KENDRICK e GARDNER (1924), ROSS (1963), KO SHIMIZU e IIZUKA (1963), COSTA et alii (1970), SCHMITTHERNER e GORDON (1970), SINCLAIR e SHURTLEFF (1975) e COSTA e LIMA NETO (1974), a infecção pelo mosaico pode reduzir a produção da planta de soja em percentagens que variam de 2 a $75 \%$.

A transmissibilidade do virus do mosaico comum da soja pela semente foi observado primeiramente por KENDRICK e GARDNER (1924), numa percentagem de $13 \%$. 
Posteriormente, outros pesquisadores mostraram que exi $\underline{s}$ tem variações significativas, que dependem dos seguintes parâmetros: variedade infectada e da estirpe do virus, podendo alcançar valores de 0,5 a $100 \%$, segundo HEINZE e KOHLER (1940), CONOVER (1948), KOSHIMIZU e IIZUKA (1963), VASCONCELOS (1963), DEBROT e ROJAS (1967), QUINIONES (1968), ROSS (1969, 1970), DUNLEAVY et alii (1970), QUINIONES e DUNLEAVY (1970), QUINIONES et alii (1971), IIZUKA (1973), COSTA e LIMA NETO (1974) e LIMA NETO (1979).

No Brasil, as manchas nas sementes de so $j a$, provenientes de plantas infectadas com o virus do mosaico comum, são conhecidas como mancha café. O quadro sintomatolögico depende principalmente do genötipo da cultivar infectada e da estirpe do virus (MORSE,1950; DUNLEAVY et alii, 1966; ROSS, 1968,1969 ; HAN e MURAYAMA, 1970; ATHOW, 1970 e DUNLEAVY, 1973). Outro fator im portante $\vec{e}$ a temperatura, sendo o ötimo considerado na faixa compreendida entre $18^{\circ} \mathrm{C}$ e $25^{\circ} \mathrm{C}$; alguns autores co mo JOHNSON (1922), CONOVER (1948), CHAMBERLAIN e KOEHER (1951), JOHNSON et alii (1954), VASCONCELOS (1963), TU e FORD (1969) e PATHAK (1974) relatam que em temperaturas superiores à ótima tendem a mascarar os sintomas. 
2.5 - Efeito do Genōtipo na Incidência de Patógenos Associados às Sementes

As sementes estão comumente associados pa tógenos capazes de causar sérias perdas às culturas. Se gundo LEACH (1979b), deve-se reconhecer, todavia, que pelo fato de um lote de sementes estar infectado por um patógeno, não significa que irá resultar numa epifitia quando essas sementes forem semeadas. Um patógeno transmissivel pela semente pode ser potencialmente perigoso; porêm, a ocorrência da doença irá depender de um nưmero complexas de variâueis, entre as quais o genötipo do hos pedeiro. Diversos relatos confirmam a ocorrência de resistência de genótipos à patógenos de sementes. Segundo PASCHALL II e ELLIS (1979), pesquisas estão sendo feitas para estudar a herdabilidade das variações genéticas entre genótipos e sua utilização através da transfe rência destes caracteres. De acordo com ALLARD (1975), em programas de melhoramento para a resistência a patógenos é básico o conhecimento da variação em patogenici dade dos agentes causais e a variação dentro da espécie hospedeira para a resistência ao patógeno. A resistência de plantas a patógenos é a capacidade de determinado genótipo evitar ou restringir a infecção e subsequen tes atividades do patógeno, quando exposto a inóculo su 
ficiente, sob condições ambientes favorāveis (ROBINSON, 1969 ; AGRIOS, 1972).

MENTEN et alii (1980) avaliaram 25 culti vares de feijão, e verificaram diferenças significativas na incidência de patógenos associados às sementes entre as cultivares. Trabalhos semelhantes foram feitos por FULCO et alii (1977); MENEZES et alii (1981); BARROS et alii (1983) e FERREIRA e MENEZES (1983). Em outras culturas como algodão, arroz, sorgo e trigo, tem sido verificadas diferenças no comportamento entre genô tipos quanto à incidência de patógenos associados às se mentes (MENEZES et alii, 1979; LIMA et alii, 1982; SOAVE et alii, 1983; CASTOR e FREDERIKSEN, 1978; GRAY et alii, 1971; GLUECK e ROONEY, 1976; NASSER et alii,1983).

A cultura da soja ê infectada por dive $\underline{r}$ sos microrganismos e quando associados a sementes reduzem a qualidade das mesmas. Os principais patógenos são: Phomopsis sojae, Colletotrichum dematium var. truncata, Cercospora kikuchii, Nematospora sp., Fusarium semitectum, Pseudomonas glycines e o virus do mosaico comum (LEHMAN, 1950 ; MURAKISHI, 1951; DUNLEAVY et alii, 1966; CRITTENDEN et alii, 1967; NICHOLSON e SINCLAIR, 1971; ATHOW e LAVIOLETE, 1973; WILCOX e ABNEY, 1973; CHAMBERLAIN e GRAY, 1974; LAWRENCE e KENNEDY, 1974; WILCOX et 
alii, 1974; DUNLEAVY, 1976). Através de experimentos vi sando estudar o comportamento de genótipos de soja à pa tógenos que infectam as sementes, DHINGRA et alii (1978, 1979) estudaram a variabilidade de diferentes cultivares às doenças füngicas das sementes, e observaram as se guintes frequências: cultivar Viçoja, $37^{\circ}$ de $P$. sojae e 15: para outros fungos; cultivares UFV-2, UFV-72-4 e UFV$72-3,0$ a $3 \%$ de $P$. sojae e 2 a $10 \%$ para outros fungos; cultivares Santa Rosa, UFV-1, UFV-76-5 e IAC-4, 9 a $10 \%$ de $P$. sojae e 11 a $13 \%$ para outros fungos.

GARDNER e KENDRICK (1924) parecem ter si do os primeiros a verificar experimentalmente que cultivares de soja diferiam em sua resistência ao virus do mosaico comum, responsável pela mancha café. Foi observado por COSTA et alii (1970) que, em quatorze cultivares testadas, encontraram-se valores que variaram de 1,0 a $45 \%$ nas percentagens de transmissão pelas sementes. Segundo LIMA NETO (1979), as cultivares de soja Bragg, Paraná e Santa Rosa diferiram na capacidade de transmitir o virus do mosaico comum da soja pelas semen tes. Estudando as cultivares de soja Viçoja, Santa Rosa, Sant'Ana, Andrews, UFV-1, Bossier, Bragg, Paranä e IAC4, ALMEIDA e MIRANDA (1978) observaram que a presença de sementes com mancha café foi constatada em todas as cul 
tivares amostradas, porem, as maiores percentagens foram observadas nas cultivares Sant'Ana, Andrews e UFV-1.

2.6 - Efeito da Época de Semeadura na Incidência de Patógenos Associados às Sementes.

Os primeiros trabalhos de pesquisas em que se estudou o efeito da época de plantio sobre o com portamento das plantas de soja foram direcionadas mais para o seu crescimento e seu desenvolvimento (NAKAGAWA, 1981). As variações anuais no comportamento das cultiva res, quanto à duração do estádio vegetativo das plantas para uma mesma época de plantio, foram atribuídas às a 1 terações de temperatura que ocorrem de ano para ano (GARDNER e ALLARD, 1930). Segundo HARTWIG (1973), o prin cipal fator de adaptação de uma cultivar de soja a determinada região é sua resposta ao comprimento do dia, pois em nenhuma outra cultura o fotoperíodo exerce tão importante papel. Conforme CosTA (1977), o mês de novem bro é a melhor época de plantio para as regiões produto ras de soja do Estado de Goiás, principalmente quando se utilizam cultivares com ciclo em torno de 150 dias,pois a maturação efetua-se a partir de abril, periodo favorä vel à colheita. 
Diversos autores relataram que o comportamento de cultivares de soja quanto ao rendimento, peso de sementes, qualidade e sanidade das sementes diferem com relação à época de plantio (FEASTER, 1949; DIMMOCK e WARREN, 1953; HARTWIG, 1954; SMITH, 1954; TORRIE e BRIGGS, 1955; LEFFEL, 1965; GREEN et alii, 1965; NICHOLSON e SINCLAIR, 1973; CARTER, 1974; BARNI e GONCALVES, 1977 ; COSTA, 1977 ; CONSTABLE, 1977; GUIMARAES et alii, 1978; NAGJU, 1979; MONTEIRO et alii, 1980; ABEL Jr., 1981; NAKAGAWA, 1981; COSTA et alii, 1984; MARCOS FILHO et alii, 1984).

De acordo com NICHOLSON e SINCLAIR(1973), NAGJU (1977 e 1979), LAM SANCHEZ e YUYAMA (1979), a: ocor rência de sementes com mancha pürpura e mancha cafë tiveram suas frequências reduzidas devido ao retardamento do plantio.

Foi verificado por WILCOX et alii (1974), DHINGRA et alii (1979a,b), WETZEL et alii (1981) e GOMES et alii (1982), que diversos microrganismos associa dos às sementes de soja apresentaram maiores frequências nas primeiras épocas de plantio. Foram observadas, por $\underline{G}$. MES et alii (1983), no município de Capinópolis, as seguintes frequências de Phomopsis sojae, Colletotrichum dematium var. truncata e total de fungos em quatro épo- 
cas de plantio: P. sojae 20,81, 11,56, 11,35 é 6,49\%; C. damatium truncata 4,88,0,78,0,65 e 0,19\%; e com to tal de fungos $38,19,16,64,15,10$ e 9,81\%. Posteriormen te GOMES et alii (1983) verificaram, no municípiode Pon ta Porã, Mato Grosso do Sul, as seguintes frequências de Phomopsis sojae, Colletotrichum dematium var. truncata e total de fungos em quatro épocas de plantio: P. sojae $15,40,12,30,3,30$ e $1,40 \% ;$ C. dematium var. truncata $5,20,1,20,0,20$ e $0,00 \%$ e com total de fungos 31,50 , $18,80,5,60$ e $1,90 \%$. 
36.

3. MATERIAL E MÉTODOS

3.1 - Local e Epoca de Realização da Pesquisa

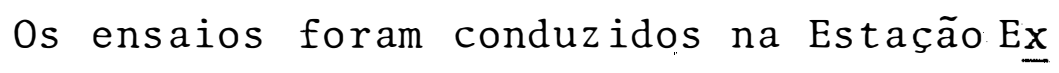
perimental de Goiânia, da Empresa Goiana de Pesquisa Agropecuária (EMGOPA) e no Laboratório de Patologia de Sementes do Departamento de Fitopatologia da Escola Superior de Agricultura "Luiz de Queiroz", da Universida de de São Paulo, em Piracicaba, no período compreendido entre novembro de 1981 a setembro de 1983. 


\section{2 - Experimento de Campo}

\subsection{1 - Instalação e condução do experimento}

A Estação Experimental de Goiânia estâ localizada na microregião do Mato Grosso de Goiảs, a uma latitude de $16^{\circ} 14^{\prime} 12^{\prime \prime}$, a longitude de $49^{\circ} 14^{\prime} 56^{\prime \prime}$ e uma altitude de 730 metros, com uma precipitação mêdia a nual de 1.500 milímetros. Os dados de precipitalção plü vial, temperatura e umidade relativa do período de outubro de 1981 a junho de 1982, do local do ensaio, foram fornecidos pela Estação Climatológica da EMGOPA (Apêndice 1). O solo é do tipo LVE (latossolo vermelho es curo), fase cerrado, com residuais de adubação anterior: Para este plantio recebeu uma adubação de manutenção no sulco de plantio de $60 \mathrm{~kg} / \mathrm{ha}$ de $\mathrm{P}_{2}{ }^{0}{ }_{5} ; 40 \mathrm{~kg} / \mathrm{ha}$ de $\mathrm{K}_{2} 0$; $30 \mathrm{~kg} / \mathrm{ha}$ de micronutrientes BR 9 e $12 \mathrm{~kg} / \mathrm{ha}$ de oxido de zinco, conforme COMISSAO ESTADUAL DE FERTILIDADE DE SOLOS (1980). Os experimentos foram conduzidos de acordo com as técnicas recomendadas para o cultivo da soja,pro cedendo-se aos tratos culturais e controle das pragas.A colheita se procedeu quando $95^{\circ}$ das vagens das plantas apresentavam a coloração típica de vagem madura, de acor do com FEHR e CAVINESS (1977). Após a colheita, as se- 
mentes foram armazenadas sob condições normais de ambien te até o término dos testes de sanidade.

\section{2 .2 - Datas de semeadura}

O ensaio se constituiu de quatro épocas de semeadura:

(a) primeira época: 21 de outubro de 1981;

(b) segunda época: 30 de outubro de 1981;

(c) terceira epoca: 09 de novembro de 1981;

(d) quarta época: 19 de novembro de 1981.

3.2.3 - Características botânicas e agronômicas dos cultivares de soja utilizadas na pesquisa.

As caracteristicas dos cultivares de soja incluídas no presente trabalho estão apresentadas nas $\underline{T} \underline{a}$ belas 1 e 2. Estes dados representam informações colhidas durante 4 anos, atravês de ensaios de competição de cultivares, realizados no Estado de Goiás e Distrito Federal. 


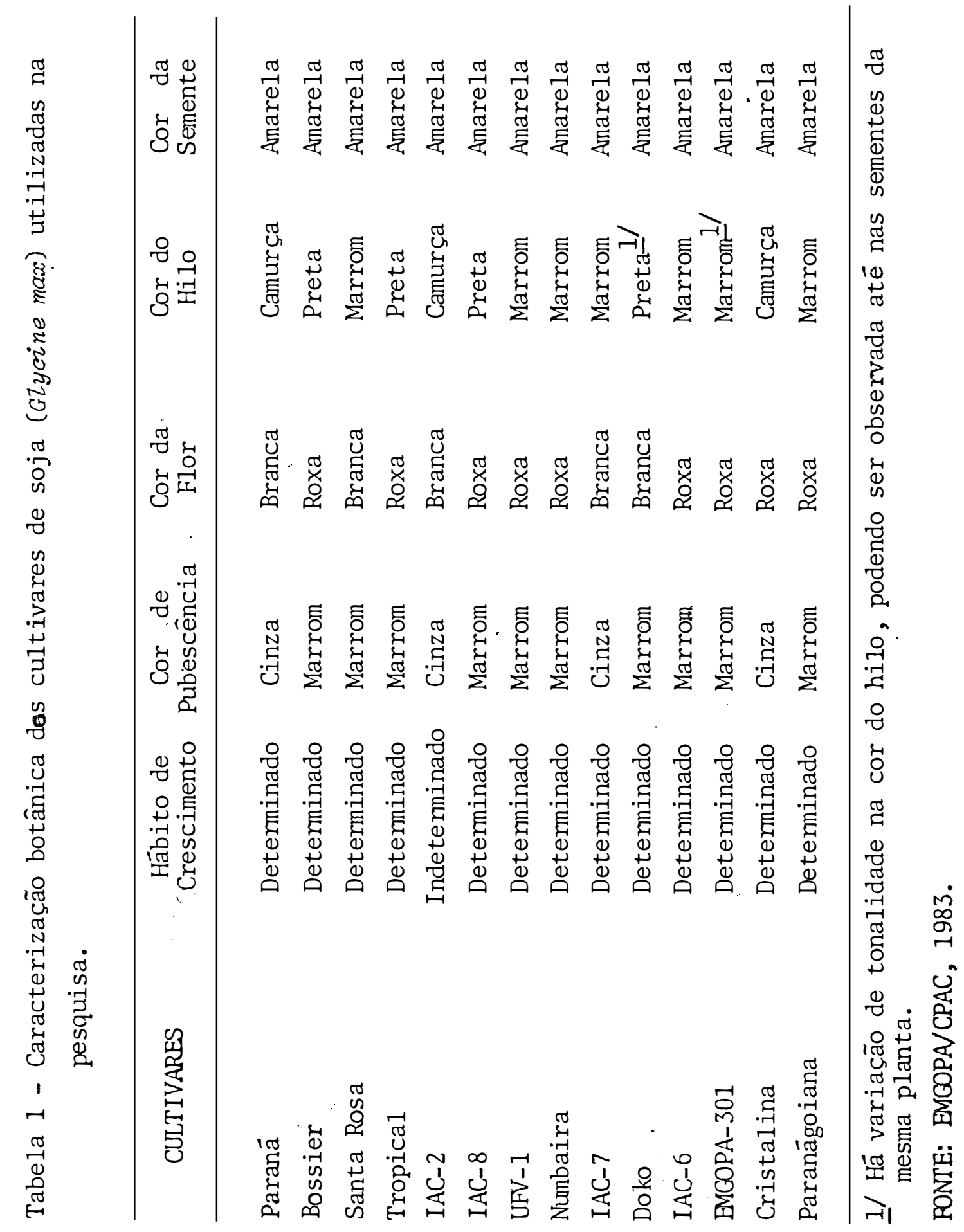


40 .

Tabela’ 2 - Caracterização agronômica dos cultivares de soja (Glycine max) utilizadas. na pesquisa.

\begin{tabular}{|c|c|c|c|c|}
\hline \multirow[b]{2}{*}{ CULTIVARES } & \multirow{2}{*}{$\begin{array}{l}\text { Produção } \\
\text { (kg/ha) }\end{array}$} & \multicolumn{2}{|c|}{ ALTURA $(\mathrm{cm})$} & \multirow{2}{*}{$\begin{array}{l}\text { Ciclo } \\
\text { (dias) }\end{array}$} \\
\hline & & Planta & $\begin{array}{l}\text { Inserção } \\
\text { da } \\
\text { 1a vagem }\end{array}$ & \\
\hline Paraná & 2.284 & 52 & 16 & 104 \\
\hline Bossier & 2.371 & 50 & 10 & 117 \\
\hline Santa Rosa & 2.690 & 52 & 10 & 120 \\
\hline Tropical & 2.193 & 86 & 23 & 125 \\
\hline IAC-2 & 2.187 & 97 & 17 & 128 \\
\hline IAC- 8 & 2.227 & 82 & 16 & 129 \\
\hline UFV-1 : & 2.173 & 47 & 11 & 131 \\
\hline Numbaira & 2.456 & 72 & 16 & 136 \\
\hline IAC-7 & 2.642 & 77 & 15 & 138 \\
\hline Doko & 2.425 & 92 & 21 & 138 \\
\hline IAC-6 & 2.352 & 92 & 18 & 139 \\
\hline EMGOPA-301 & 2.794 & 89 & 17 & 140 \\
\hline Cristalina & 2.548 & 69 & 14 & 140 \\
\hline Paranagoiana & 2.800 & 89 & 17 & 140 \\
\hline
\end{tabular}

FONTE: EMCOPA/CPAC, 1983. 


\subsection{4 - Delineamento experimental}

O delineamento experimental usado foi o em blocos ao acaso, esquema fatorial $14 \times 4$ (14 genótipos e 4 épocas de semeadura), com 3 repetições, perfazen do um total de 168 parcelas. As parcelas foram constituí das de quatro fileiras com $5,0 \mathrm{~m}$ de comprimento, espaçadas entre si de 0,60 m. A população utilizada no experimento foi de 400.000 plantas por hectare conforme RECOMENDAÇOES DA EMGOPA/CPAC (1981). Para todas as observa ções foram consideradas somente as duas fileiras centrais, eli minando-se $0,50 \mathrm{~m}$ em cada uma das extremidades da parce$1 \mathrm{a}$.

\subsection{5 - Avaliação das características agronômi cas}

No experimento, foram avaliados as seguintes características agronômicas: (a) ciclo: período em dias da semeadura à maturação, quando $95^{\circ}$ das vagens das plantas apresentavam a coloração típica de vagem madura, de acordo com FEHR e CAVINESS (1977); (b) altura 
de planta e inserção da primeira vagem: medidas em 10 plantas por parcela, nas partes mais homogêneas; (c) grau de acamamento: usou-se uma escala arbiträria, atri buindo notas de 1 a 5, na maturação, conforme critério descrito pelo U.S. REGIONAL SOYBEAN LABORATORY (1972):

1: quase todas as plantas erectas;

2: todas as plantas levemente inclinadas ou algumas plantas acamadas;

3: todas as plantas moderadamente inclinadas ou $25 \%$ a $50 \%$ das plantas acamadas;

4: todas as plantas consideravelmente inclinadas ou $50 \%$ a $80 \%$ das plantas acamadas;

5: todas as plantas acamadas;

(d) produção: as sementes de cada parcela ütil foram pe sadas separadamente, com precisão de grama, transforman do-se o resultado em quilograma por hectare; (e) pesode sementes: foram coletadas ao acaso, por parcela ütil, amostras contendo 1000 sementes da fração sementes inteiras previamente preparadas; em seguida foram pesadas e o resultado transformado em gramas. 
3.3 - Experimentos de Laboratório

3.3.1 - Análise visual de sementes manchadas

Amostras de sementes representativas das 168 parcelas experimentais (item 3.2.4) foram separadas em subamostras de 100 gramas de sementes puras. Após a pesagem, foram separadas das sementes aparentemente sadias, sementes com mancha pürpura, com mancha de levedu ra e com mancha café. A avaliação se procedeu da seguin te maneira: para sementes com mancha pürpura $\epsilon^{-}$sementes com mancha café, foram consideradas somente as sementes que apresentavam os sintomas típicos das duas moléstias; para mancha de levedura, primeiramente foram feitos vărios isolamentos do patógeno em meio de cultura BDA(200 g de batata; 2 g de dextrose; $18 \mathrm{~g}$ de ágar; āgua destilada q.s.p. $1.000 \mathrm{~m} 1$ ); a partir dos dados obtidos nos isolamentos, foi padronizado um sintoma típico da doença na semente. 
3.3.2 - Anảlise da sanidade de sementes de soja

Amostras de sementes representativas das 168 parcelas experimentais (item 3.2.4) foram examinadas pelos métodos do papel de filtro e papel de filtro com congelamento (TEMPE, 1963; LIMONARD, 1966; TEMPE, 1970 ; NEERGAARD, 1977; LASCA, 1978; YORINORI et alii, 1979), cerca de 8 meses após o armazenamento.

(a) Mëtodo do papel de filtro ("Blotter method"): cem sementes de cada amostra foram distribuídas em placas de Petri de plástico $(100 \times 15 \mathrm{~mm})$, contendo 3 folhas de papel de filtro esterilizadas, previamente embe bidas em àgua destilada (10 sementes por placa) e incubadas a $20^{\circ} \mathrm{C} \pm 1^{\circ} \mathrm{C}$ por 8 dias, sob luz pröxima a ultra-violeta (NUV), segundo um regime de alternância de 1 uz e escuro de 12 horas. Após esse período, as sementes fo ram examinadas sob o microscôpio estereoscôpico; estruturas microbianas foram observadas ao microscópio composto para confirmação das observações. Para alguns dos microrganismos, a identificação foi realizada somente a nível de gênero, de acordo com BARNETT e HUNTER (1972); para outros, a nível de espëcie (LUTTRELL, 1947; ARX, 1957 ; BOOTH, 1971 ; ELLIS, 1971; ELLIS, 1976 ; DHINGRA e SINCLAIR, 1978 ; HINO e TOKESHI, 1978). 
(b) Mëtodo do papel de filtro com congelamento ("deep-freezing method"): cem sementes de cada amostra foram distribuídas em placas de Petri de plästico (100 x $15 \mathrm{~mm})$, contendo 3 folhas de papel de filtro estereli $z$ adas, previamente embebidas em água destilada (10 sementes por placa) e mantidas a $20^{\circ} \mathrm{C} \pm 1^{\circ} \mathrm{C}$ por 24 horas; seguiram-se 24 horas sob $-18^{\circ} \mathrm{C}$ e, finalmente, nova incu bação por 6 dias a $20^{\circ} \mathrm{C} \pm 1^{\circ} \mathrm{C}$, sob luz próxima a ultra-violeta (NUV), sob um regime de alternância de luz e es curo de 12 horas; após esse período as sementes foram examinadas da mesma maneira descrita no izem 3.3.2.a.

3.4. Anälise Estatística dos Dados

Foram realizadas anälises de variância dos dados de duração do ciclo (dias), rendimento ( $\mathrm{kg} / \mathrm{ha}$ ) indice de acamamento (1-5), altura de planta (cm), altura de inserção das primeiras vagens $(\mathrm{cm})$, peso de 1000 sementes e porcentagens de sementes com: mancha pürpura, man cha café, mancha de levedura, Phomopsis sojae, Colleto trichum dematium var. truncata, Cercospora kikuchii e Fu sarium semitectum.

Todos os dados expressos em porcentagens foram transformados em arcsen $\sqrt{\left(x_{0}^{0}+0,5\right) \sqrt{100}}$, (GOMES, 
1970)

Para a comparação entre as médias utilizou-se o teste Tukey ao nível de 5\% de probabilidade, de acordo com as recomendações encontradas em GOMES (1970). 
47.

4. RESULTADOS

Os resultados dos testes de sanidade (itens 3.3.1 e 3.3.2) estão apresentados de acordo com os diversos parâmetros utilizados para avaliação da qualidade das sementes; os dados referentes à avaliação dos caracteres agronômicos estudados (item 3.2.5) estão apre sentados nos Apêndices 2 a 7 .

4.1 - Efeito do Genötipo da Epoca de Semeadura na Incidência de Mancha Pürpura em Sementes de Soja.

Os resultados obtidos para este parâmetro são apresentados, resumidamente, na Tabela 3. Atravês da anälise de variância foi possível detectar efeito estatisticamente significativo para cultivares, êpo 
cas de semeadura e interação cultivares $x$ épocas de semeadura. Entre os cultivares analisadas. UFV-1 foi o que apresentou menor frequência de sementes com mancha pürpura $(0,25 \%)$, enquanto $\mathrm{ocv}$. Paranagoiana apresentou a maior frequência $(4,70 \%)$. Entre as épocas de semeadura, a primeira foi a que apresentou a maior frequência $(1,18 \%)$ de sementes com mancha púrpura, havendo uma diminuição da percentagem de sementes com sintomas à medida que se atrasou o plantio.

O efeito significativo para a interação cultivares $x$ épocas de semeadura indicou que o comporta mento de cultivares depende da época de semeadura; de forma anảloga, o efeito da época de semeadura depende do cultivar considerado. Assim, embora o cv. Paranagoiana tenha apresentado a maior incidência de sementes com man cha pürpura em todas as épocas de semeadura condisera das, o mesmo não se passou com UFV-1 quanto à menor incidência de mancha pürpura; na primeira e segunda época de semeadura, a menor frequência de sementes com sintomas foi observada para o cv. Cristalina; na terceira, o cv. IAC-8 e na quarta para o UFV-1. Não foi possível manter o ordenamento dos cultivares independentemente da época de semeadura, sendo observadas diversas inversões na frequência dos sintomas. 
Tabela 3 - Efeito do genótipo da época de semeadura na frequência ( $\left.\begin{array}{c}0 \\ 0\end{array}\right)$ de mancha pürpura em sementes de soja;[GZycine $\max$ (L.) Merril1], no Estado de Goiảs. Piracicaba, SP, 1983.

\begin{tabular}{|c|c|c|c|c|c|}
\hline \multirow{2}{*}{ CULTIVARES } & \multicolumn{4}{|c|}{ EPOCAS DE SEMEADURAal } & \multirow{2}{*}{ MEDIA } \\
\hline & 21/out. & 30/out. & 09/nov. & 19/nov. & \\
\hline$U F V-1$ & 0,28 & 0,32 & 0,28 & 0,14 & $0,25 \mathrm{a}$ \\
\hline Cristalina & 0,12 & 0,31 & 0,24 & 0,53 & $0,30 \mathrm{ab}$ \\
\hline IAC- 8 & 0,36 & 0,39 & 0,16 & 0,36 & $0,32 \mathrm{ab}$ \\
\hline Numbaira & 0,42 & 0,33 & 0,20 & 0,33 & $0,32 \mathrm{ab}$ \\
\hline IAC-2 & 0,18 & 0,13 & 0,37 & 0,62 & $0,32 \mathrm{ab}$ \\
\hline Tropical & 0,31 & 0,41 & 0,36 & 0,37 & $0,36 \mathrm{ab}$ \\
\hline IAC-6 & 0,39 & 0,64 & 0,29 & 0,22 & $0,38 \mathrm{ab}$ \\
\hline Santa Rosa & 0,64 & 0,45 & 0,31 & 0,15 & $0,39 \mathrm{abc}$ \\
\hline Doko & 0,33 & 0,56 & 0,33 & 0,90 & $0,53 \mathrm{abc}$ \\
\hline IAC-7 & 0,80 & 0,62 & 0,32 & $\cdot 0,63$ & $0,59 \mathrm{abcd}$ \\
\hline EMOOPA 301 & 2,33 & 0,95 & 0,58 & 0,30 & $1,04 \mathrm{bcd}$ \\
\hline Bossier & 3,26 & 1,00 & 0,94 & 0,11 & $1,33 \mathrm{~cd}$ \\
\hline Paraná & 3,40 & 2,04 & 0,77 & 0,25 & $1,61 \quad \mathrm{~d}$ \\
\hline Paranagoiana & 3,69 & 5,21 & 4,23 & 5,67 & 4,70 \\
\hline Médiab/ & $1,18 \mathrm{c}$ & $0,95 b c$ & $0,76 \mathrm{ab}$ & $0,75 \mathrm{a}$ & \\
\hline
\end{tabular}

a/ Média de 3 repetições.

b/ Médias seguidas da mesma letra não diferiram significativamente entre si pelo teste Tukey ao nível de $5 \%$ de probabilidade. 
Quanto à influência do genōtipo no ordenamento do efeito das épocas de semeadura na incidência de mancha púrpura, pode-se comparar as cvs. Paraná e IAC-2; para a primeira cultivar, houve um nitido decréscimo na frequência de sementes com sintomas a partir da primeira época de semeadura; jâ para ocv. IAC-2, a tendência foi inversa. Interações tambëm puderam ser detectadas para a cv. Paranagoiana.

4.2 - Efeito do Genótipo da Epoca de Semeadura na Incidência de Mancha Café em Sementes de Soja

Os resultados obtidos para este parâmetro são apresentados, resumidamente, na Tabela 4. Atravês da anảlise de variância foi possível detectar efeito estatisticamente sïgnificativo para cultivares; não houve efeito estatístico para ëpocas de semeadura e para interação cultivares $x$ épocas de semeadura. Entre os cultí vares analisadas, Paranā, Numbaira, IAC-6, Paranagoiana, IAC-2 e Doko foram os que apresentaram menores frequências de sementes com mancha café ( 0 a $0,06 \%)$; em contraste, os cvs. UFV-1 e Santa Rosa apresentaram as mais altas frequências $(0,18$ e $0,21 \%)$ de sementes com mancha cafè. 
Tabela 4 - Efeito do genótipo da época de semeadura na frequência $\left(\begin{array}{l}0 \\ 0\end{array}\right)$ de mancha café em sementes de so ja [Glycine $\max$ (L.) Merrill], no Estado de Goiās. Piracicaba, SP, 1983.

\begin{tabular}{|c|c|c|c|c|c|}
\hline \multirow{2}{*}{ CULTIVARES } & \multicolumn{4}{|c|}{ EPOCAS DE SEMEADURA- } & \multirow{2}{*}{ MEDIA } \\
\hline & 21/out. & 30/out. & 09/nov. & 19/nov. & \\
\hline Paraná & 0,00 & 0,00 & 0,00 & 0,00 & $0,00 \mathrm{a}$ \\
\hline Numbaira & 0,00 & 0,00 & 0,00 & 0,00 & $0,00 \mathrm{a}$ \\
\hline IAC-6 & 0,00 & 0,00 & 0,00 & 0,00 & $0,00 \mathrm{a}$ \\
\hline Paranagoiana & 0,00 & 0,00 & 0,00 & 0,00 & $0,00 \mathrm{a}$ \\
\hline IAC-2 & 0,05 & 0,05 & 0,04 & 0,05 & $0,05 a$ \\
\hline Doko & $0,00^{\circ}$ & 0,00 & 0,00 & 0,22 & $0,06 \mathrm{ab}$ \\
\hline IAC-7 & 0,12 & 0,09 & 0,04 & 0,16 & $0,10 \mathrm{abc}$ \\
\hline Cristalina & 0,15 & 0,24 & 0,08 & 0,00 & $0,12 \mathrm{abc}$ \\
\hline $\mathrm{AM} \odot \mathrm{PA}-301$ & 0,05 & 0,06 & 0,00 & 0,41 & $0,13 \mathrm{abc}$ \\
\hline Tropical & 0,22 & 0,17 & 0,05 & 0,40 & $0,14 \mathrm{abc}$ \\
\hline Bossier & 0,27 & 0,18 & 0,11 & 0,10 & $0,17 \mathrm{bc}$ \\
\hline IAC- 8 & 0,06 & 0,12 & 0,26 & 0,26 & $0,17 \mathrm{bc}$ \\
\hline UFV-1 & 0,23 & 0,14 & 0,15 & 0,18 & $0,18 \quad \mathrm{c}$ \\
\hline Santa Rosa & 0,16 & 0,15 & 0,22 & 0,31 & $0,21 \quad c$ \\
\hline Mëdia & $0,09 \mathrm{a}$ & $0,08 \mathrm{a}$ & $0,07 a$ & $0,15 a$ & \\
\hline
\end{tabular}

a/ Média de 3 repetiçōes.

E/ Médias seguidas da mesma letra não diferiram significativamente entre si pelo teste Tukey ao nível de $5^{\circ}$ de probabilidade. 
4.3 - Efeito do Genótipo e da Epoca de Semeadura na Incidência de Mancha de Levedura em Sementes de Soja

Os resultados obtidos para este parâmetro são apresentados, resumidamente, na Tabela 5. Atravês da anälise de variância foi possível detectar efeito estatisticamente significativo para cultivares, épocas de semeadura e interação cultivares $x$ épocas de semeadura. Entre os cultivares analisados, IAC-6 foi o que apresentou menor frequência de sementes com mancha de levedura $(0,14 \%)$, enquanto $0 \mathrm{cv}$. Paranả apresentou a mais alta frequência $(2,62 \%)$. Entre as épocas de semeadura, a primeira foi a que apresentou a maior frequência de mancha de levedura $(1,26 \%)$, havendo uma diminuição de percentagem de sementes com mancha de levedura à medida que se atrasou o plantio.

A interação significativa entre cultiva res e épocas de semeadura indicou que o comportamento de cultivares dependen da época de semeadura, assim como o efeito da época de semeadura depende do cultivar con siderada. Assim, o ordenamento dos cultivares não é o mesmo para as quatro ëpocas de semeadura estudadas. Para a primeira época de semeadura, os cvs. Paraná, Paranagoiana e EMGOPA-301 foram os que apresentaram maiores 
frequências de sementes com mancha de levedura, enquanto o cv. IAC-6 apresentou a menor frequência. Nas segun da e terceira épocas, o cv. Paraná continuou a ser o que apresentou maior frequência de sementes com sintomas; entretanto, as menores frequências foram apresenta das pelo cv. UFV-1. Jä na quarta época, os extremos foram apresentados pelos cvs. Paranagoiana $(0,86 \%)$ e Numbaira e Bossier $(0 \%)$.

Quanto à influência do genótipo no ordenamento do efeito das épocas de semeadura ma incidência de mancha de levedura, pode-se comparar os cvs. Paraná e Tropical; enquanto para o cv. Paraná houve uma clara tendência de decréscimo na frequência de sementes com sintomas a partir da primeira época de semeadura, para o cv. Tropical o ordenamento foi diferente, havendo a maior frequência de sementes com sintomas na ủltima épo ca de semeadura. Interações semelhantes foram observadas para diversos outros cultivares. 
Tabela 5 - Efeito do genótipo e da época de semeadura na frequência $\left(\begin{array}{l}0 \\ 0\end{array}\right)$ de mancha de levedura em sementes de soja [Glycine max (L.) Merrill], no Estado de Goiás. Piracicaba, SP, 1983.

\begin{tabular}{|c|c|c|c|c|c|}
\hline \multirow{2}{*}{ CULTIVARES } & \multicolumn{4}{|c|}{ EPOCAS DE SEMEADURA } & \multirow{2}{*}{ MÉDIA } \\
\hline & 21/out. & 30/out. & 09/nov. & 19/nov. & \\
\hline IAC- 6 & 0,06 & 0,18 & 0,24 & 0,09 & $0,14 a$ \\
\hline IAC-7 & 0,31 & 0,26 & 0,16 & 0,04 & $0,19 \mathrm{ab}$ \\
\hline IAC- 8 & 0,18 & 0,23 & 0,32 & 0,10 & $0,21 \mathrm{ab}$ \\
\hline UFV-1 & 0,64 & 0,09 & 0,14 & 0,04 & $0,23 a b$ \\
\hline Doko & 0,28 & $0,2 i$ & 0,22 & 0,38 & $0,27 \mathrm{ab}$ \\
\hline Numbaira & 0,75 & 0,39 & 0,14 & 0,00 & $0,32 \mathrm{ab}$ \\
\hline Santa Rosa & 0,89 & 0,20 & 0,16 & 0,26 & $0,38 \mathrm{ab}$ \\
\hline Tropical & 0,53 & 0,10 & 0,25 & 0,69 & $0,39 \mathrm{ab}$ \\
\hline Cristalina & 0,69 & 0,80 & 0,16 & 0,13 & $0,44 \mathrm{ab}$ \\
\hline IAC-2 & 1,20 & 0,14 & 0,47 & 0,04 & $0,46 a b$ \\
\hline EMGOPA-301 & 2,60 & 0,27 & 0,21 & 0,05 & $0,78 \mathrm{ab}$ \\
\hline Bossier & 2,30 & 1,34 & 0,21 & 0,00 & $0,96 \mathrm{~b}$ \\
\hline Paranagoiana & 2,60 & 0,84 & 0,87 & 0,86 & $1,30 \quad c$ \\
\hline Paraná & 4,61 & 4,15 & 1,28 & 0,46 & $2,62 \quad d$ \\
\hline Médiąl & $1,26 \mathrm{~d}$ & $0,66 c$ & $0,34 b$ & $0,23 a$ & \\
\hline
\end{tabular}

a/ Média de 3 repetições.

b/ Médias seguidas da mesma letra não diferiran significativanente entre si pelo teste Tukey ao nível de 5\% de probabilidade. 
4.4 - Efeito do Genótipo e da Epoca de Semeadura na Deteç̧ão de Microrganismos Associados a Sementes de Soja Através do Método do Papel de Filtro, Com e Sem Congelamento

Empregando-se dois métodos para testes de sanidade (papel de filtro e papel de filtro com congelamento), foi realizado um levantamento da microflora associada a sementes de soja das 168 amostras provenien tes do Estado de Goiás. Foram identificados os seguintes microrganismos: Phomopsis sojae, Colletotrichum dematium spp. truncata, Cercospora kikuchii, Cerrcosporaso jina, Fusarium semitectum, Macrophomina phaseolina, Pho ma sp., Drechslera sp., Alternaria tenuis, Aspergillus sp., Penicillium sp., Paecilomyces sp., Epicoccum sp., Pestalotia sp., Chatomium sp., Rhizopus sp., Curvularia sp., Cladosporium sp., Stemphylium sp., Nigrospora sp., e bactérias não identificadas (Tabelas 6 a 19).

Embora não tenha sido feita a análise es tatística dos resultados para todos os microrganismos identificados, foi verificado que o comportamento dos cultivares foi diferente quanto à frequência dos patóge nos da cultura ( $P$. sojae, $C$. dematium var. truncata, $C$. sojina, F. semitectum e M. Phaseolina); o mesmo aconte- 
ceu para as peocas de semeadura. Foi observado ainda que, dos dois métodos de deteç̧ão avaliados na recuperação destes patógenos, o método do papel de filtro sem conge lamento proporcionou uma maior recuperação dos microrga nismos de importância patogênica.

Com relação aos microrganismos sapröfitas, os resultados das Tabelas 6 a 19 mostram que as fre quências de A. tenuis, Penicilium sp., Aspergizlus sp., Cladosporium sp., Paecilomyces sp., Pestalotia sp., Cur vularia sp., Rhizopus sp., Epicoccum sp., Stemphylium sp., Chaetomium sp., Phoma sp. e Drechslera sp., associados às sementes de soja, foram afetados pelos cultivares e épocas de semeadura. Dos dois métodos de detecção avaliádos, o método do papel de filtro sem congelamento recuperou maiores frequências destes microrganismos.

De acordo com os resultados, apresentados nas Tabelas 6 a 19, o método do papel de filtro com con gelamento recuperou maiores frequências de bactérias não identificadas; verificou-se que o comportamento dos cul tivares e épocas de semeadura foram diferentes quanto à frequência de sementes associadas a bactérias não identificadas. 


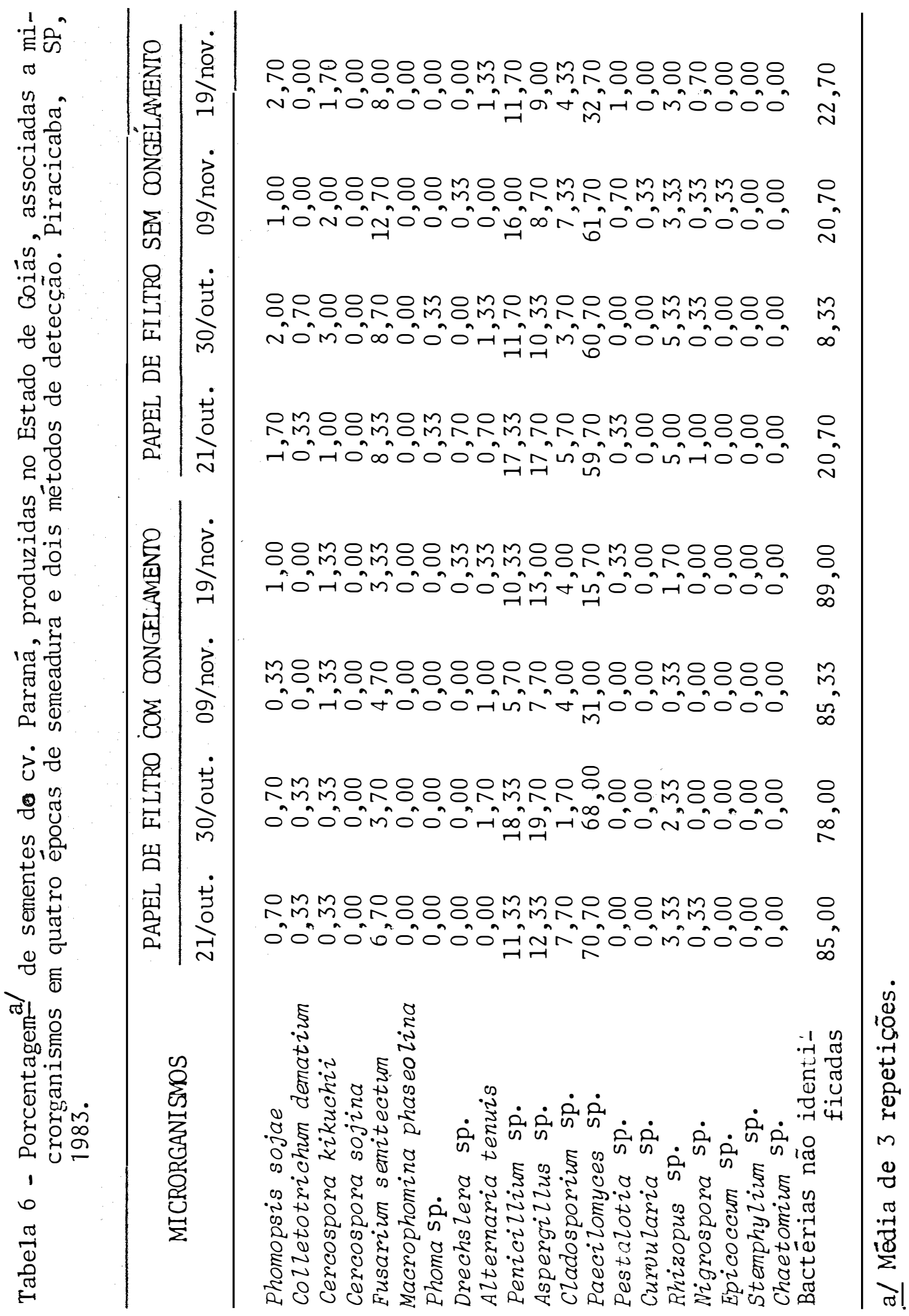


舀号

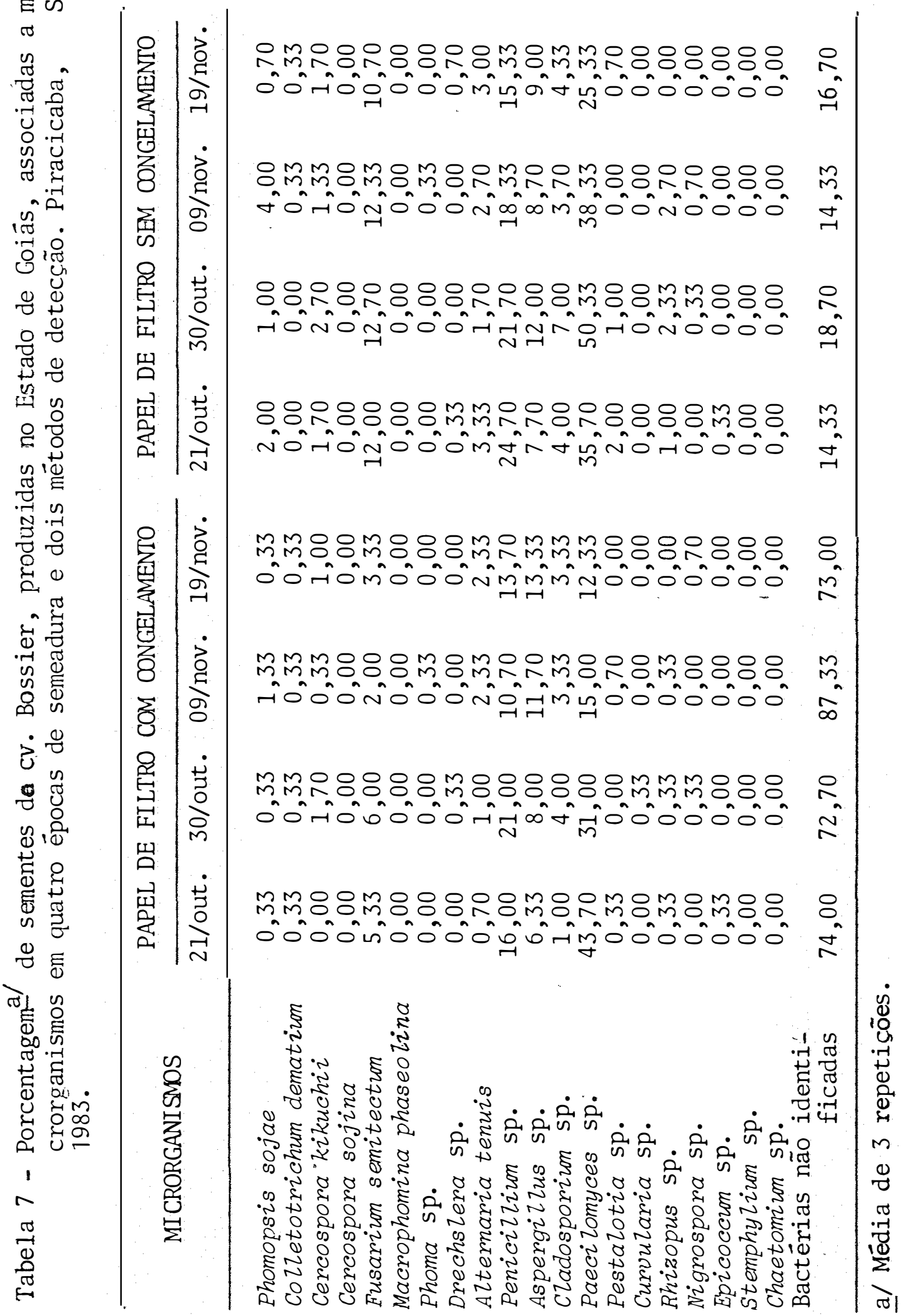




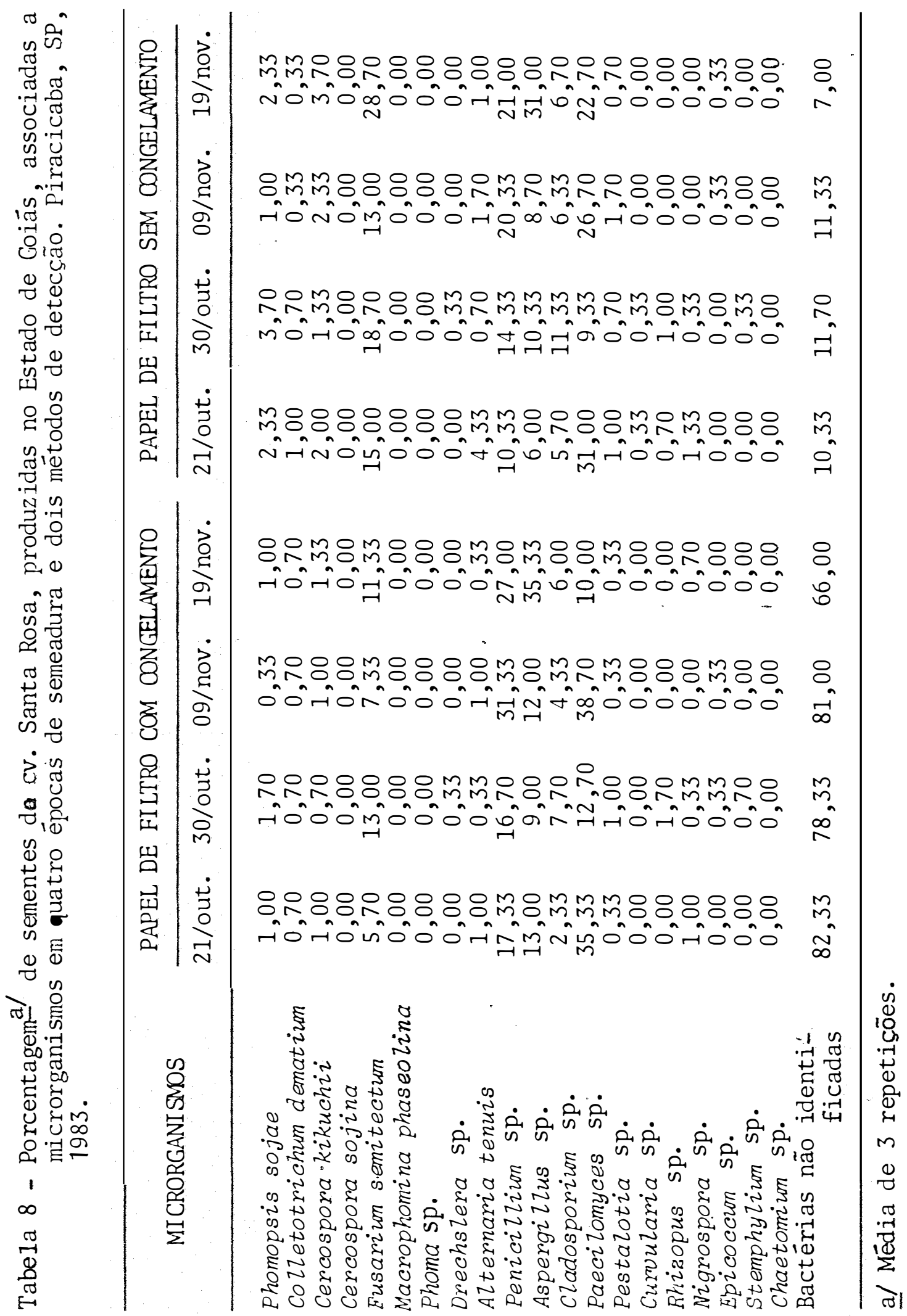




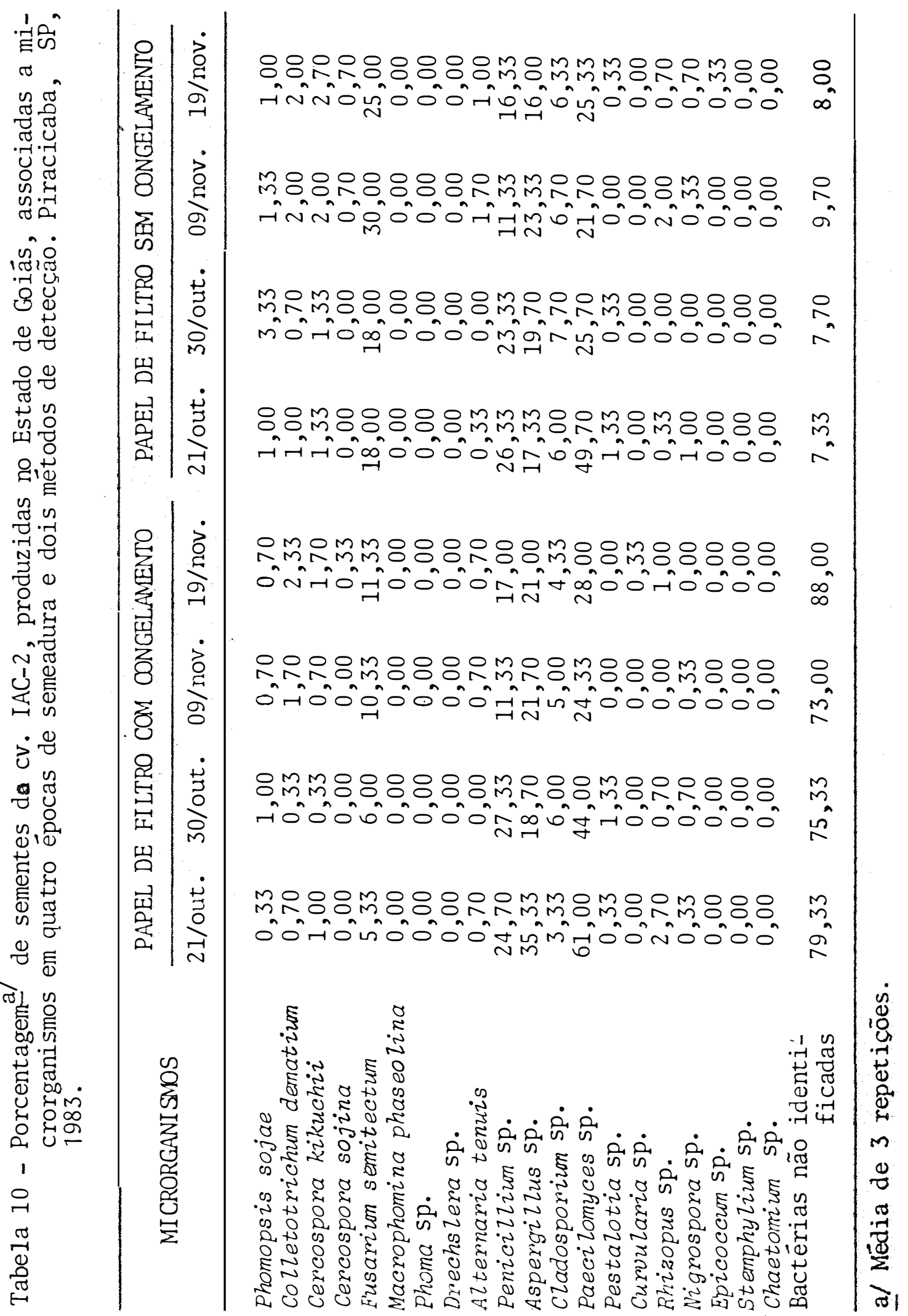




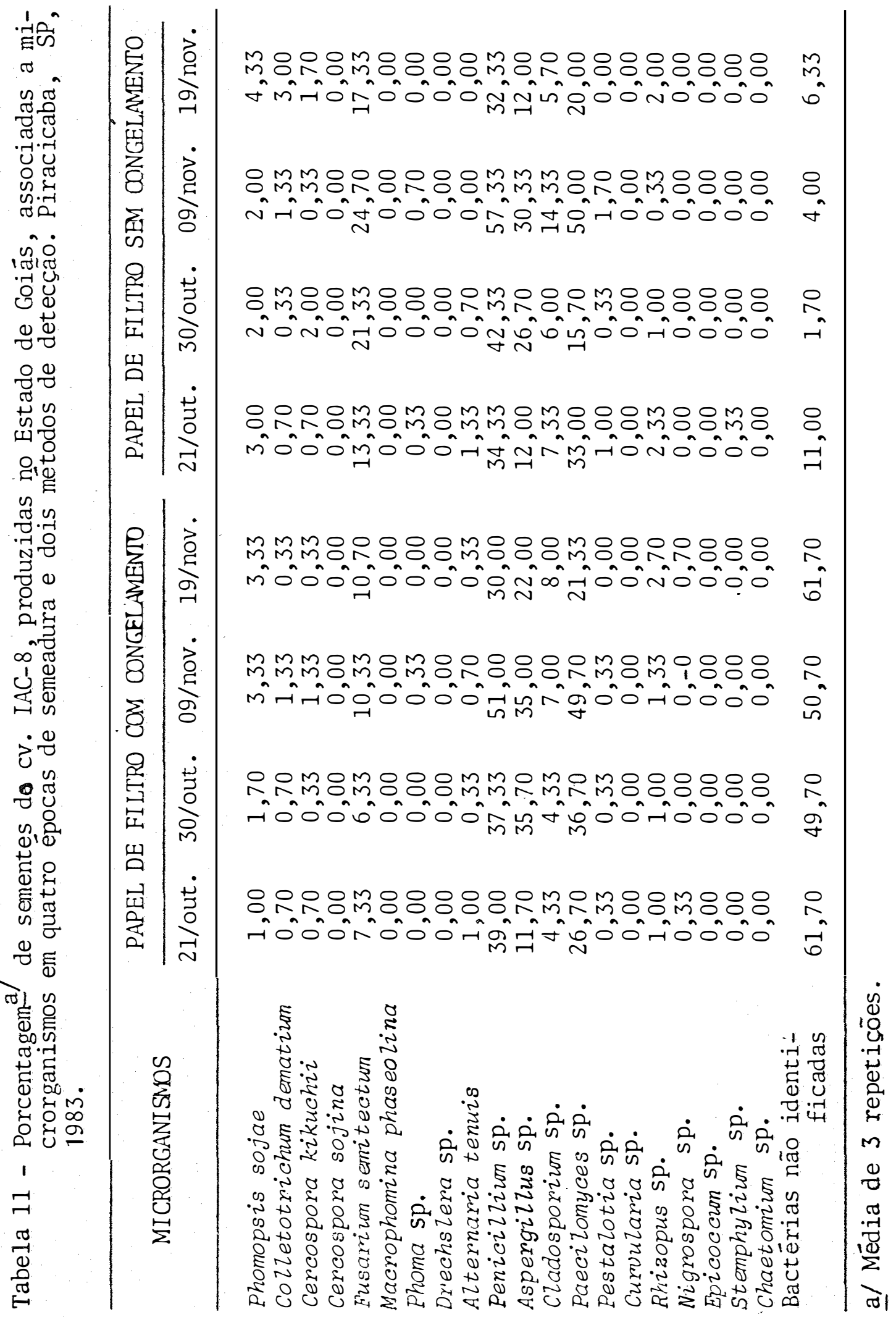




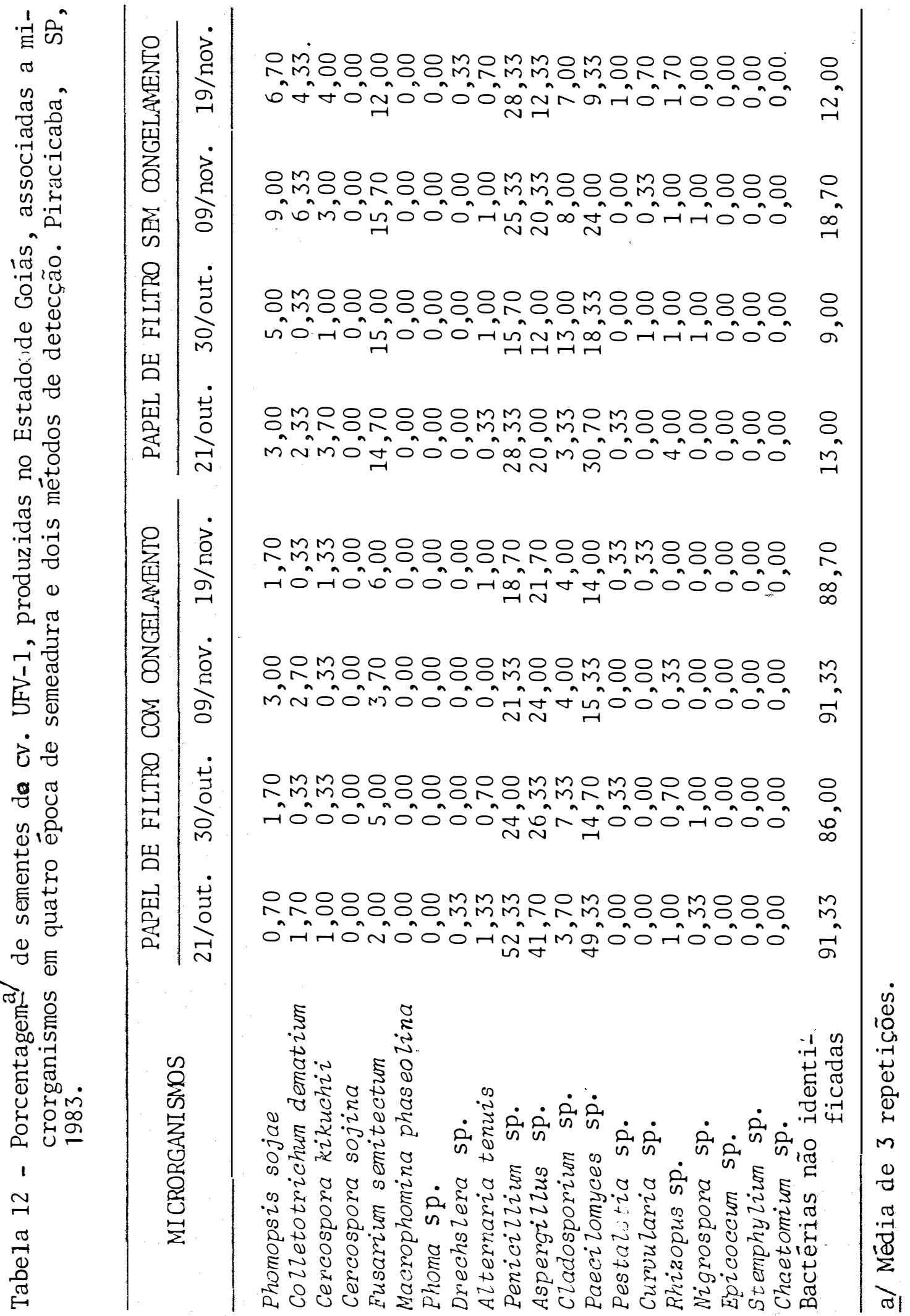




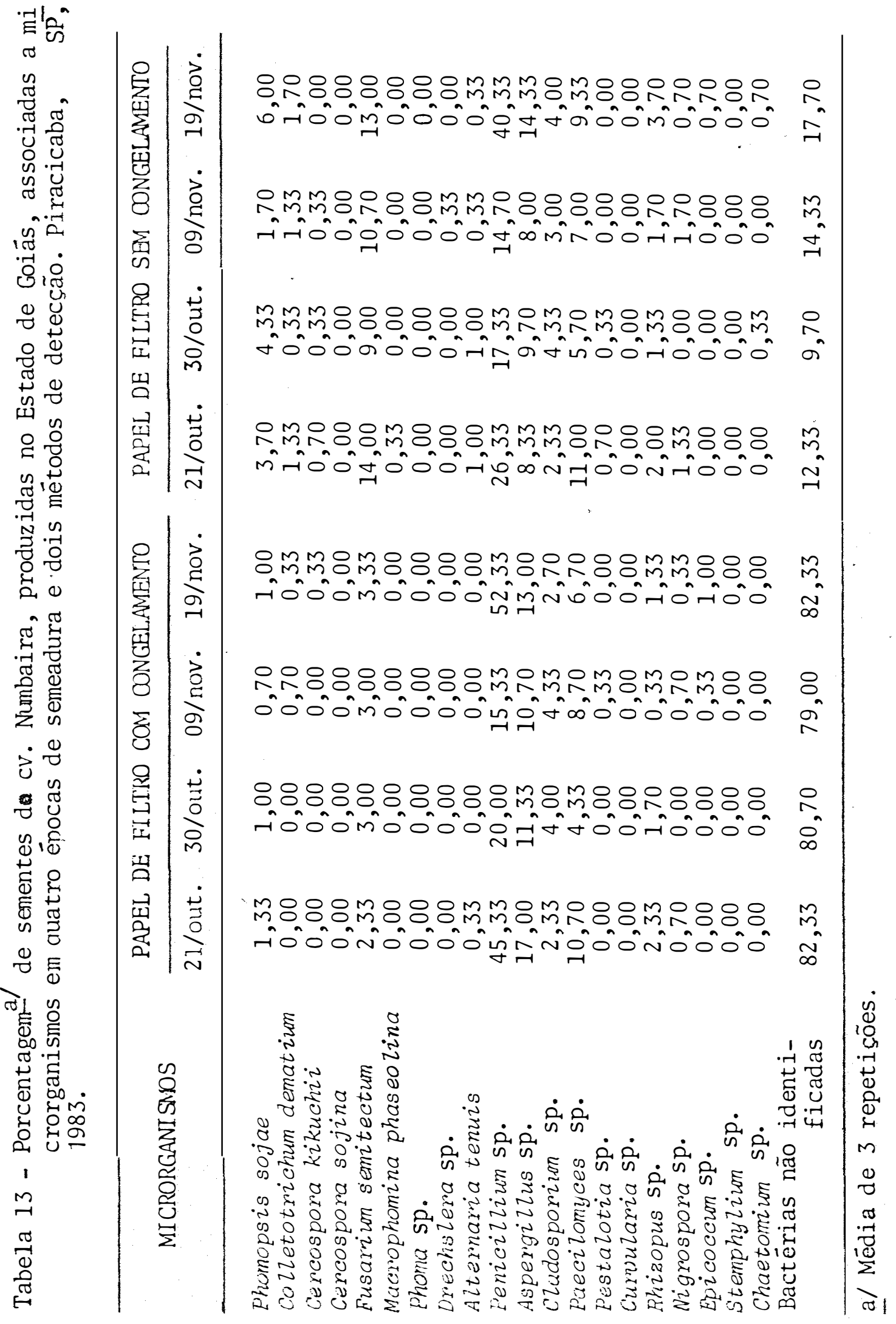


65.

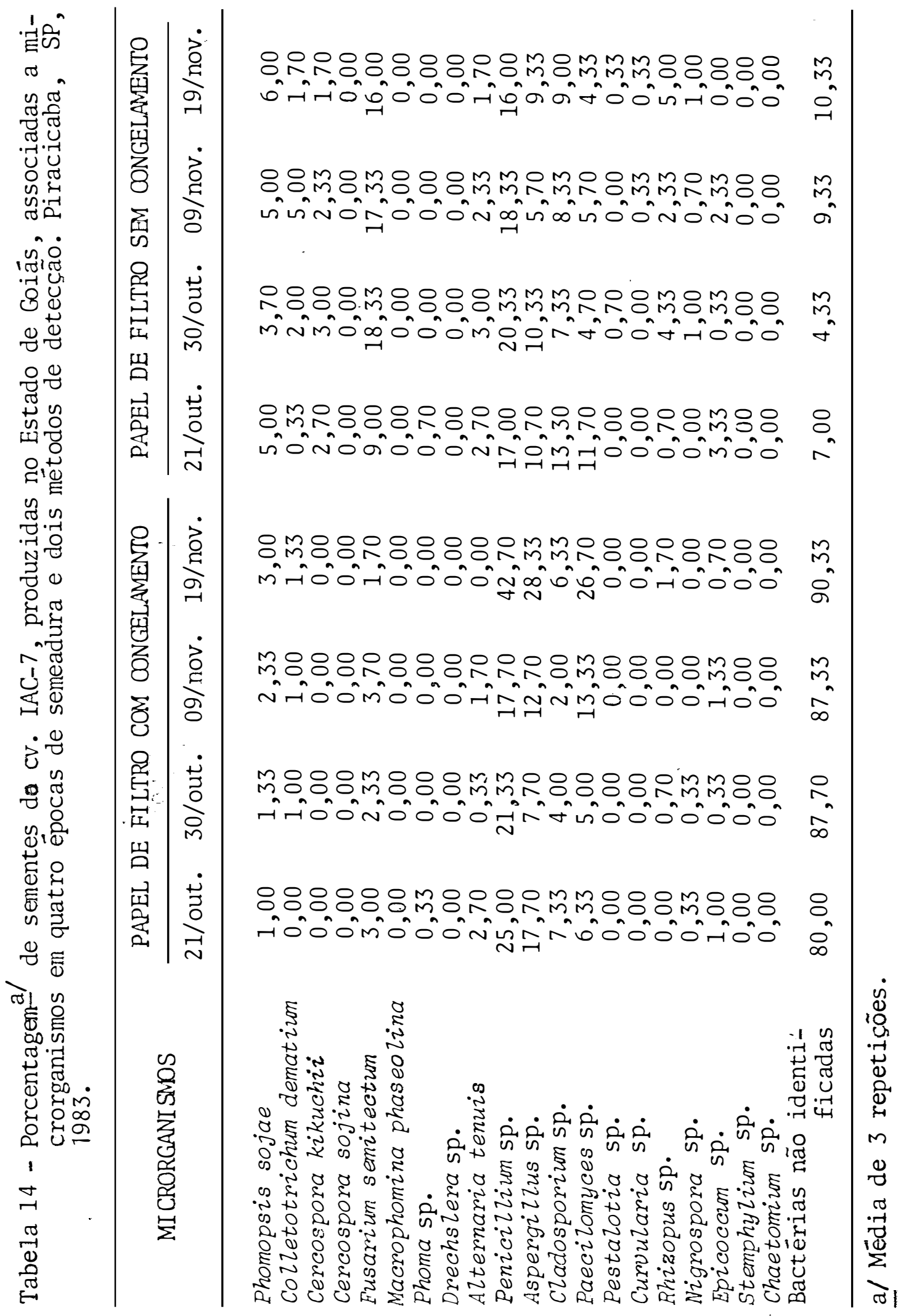


66.

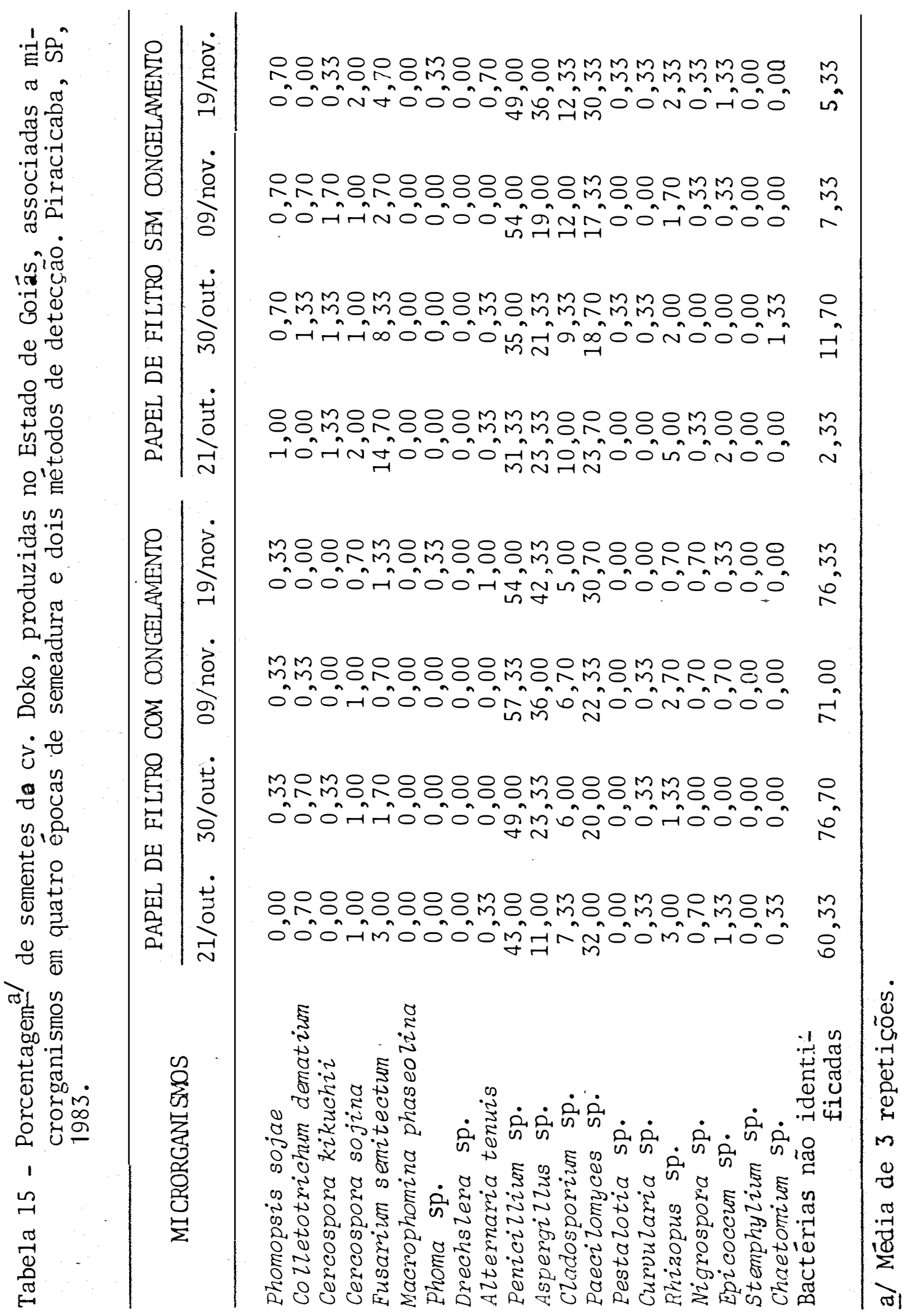




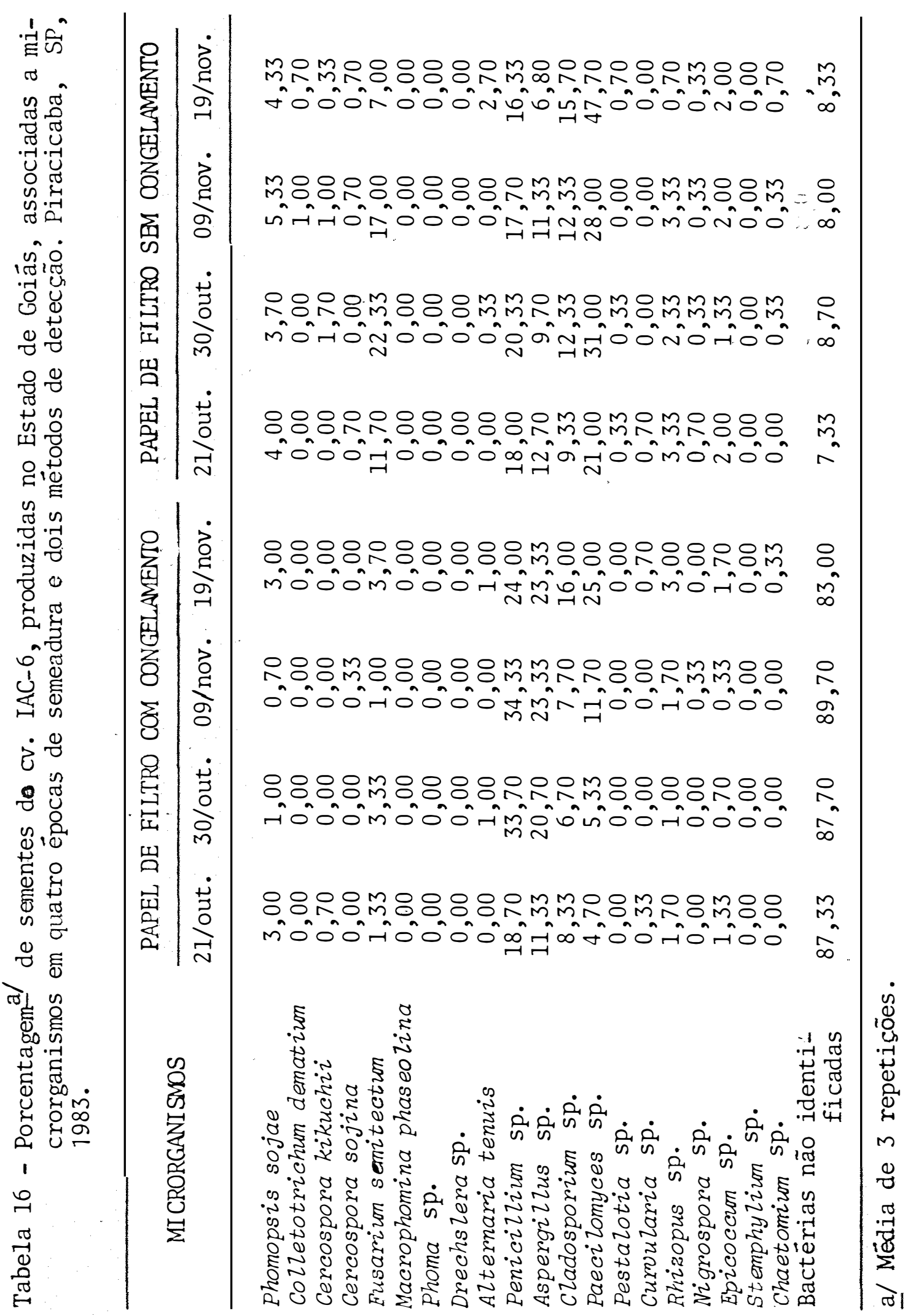




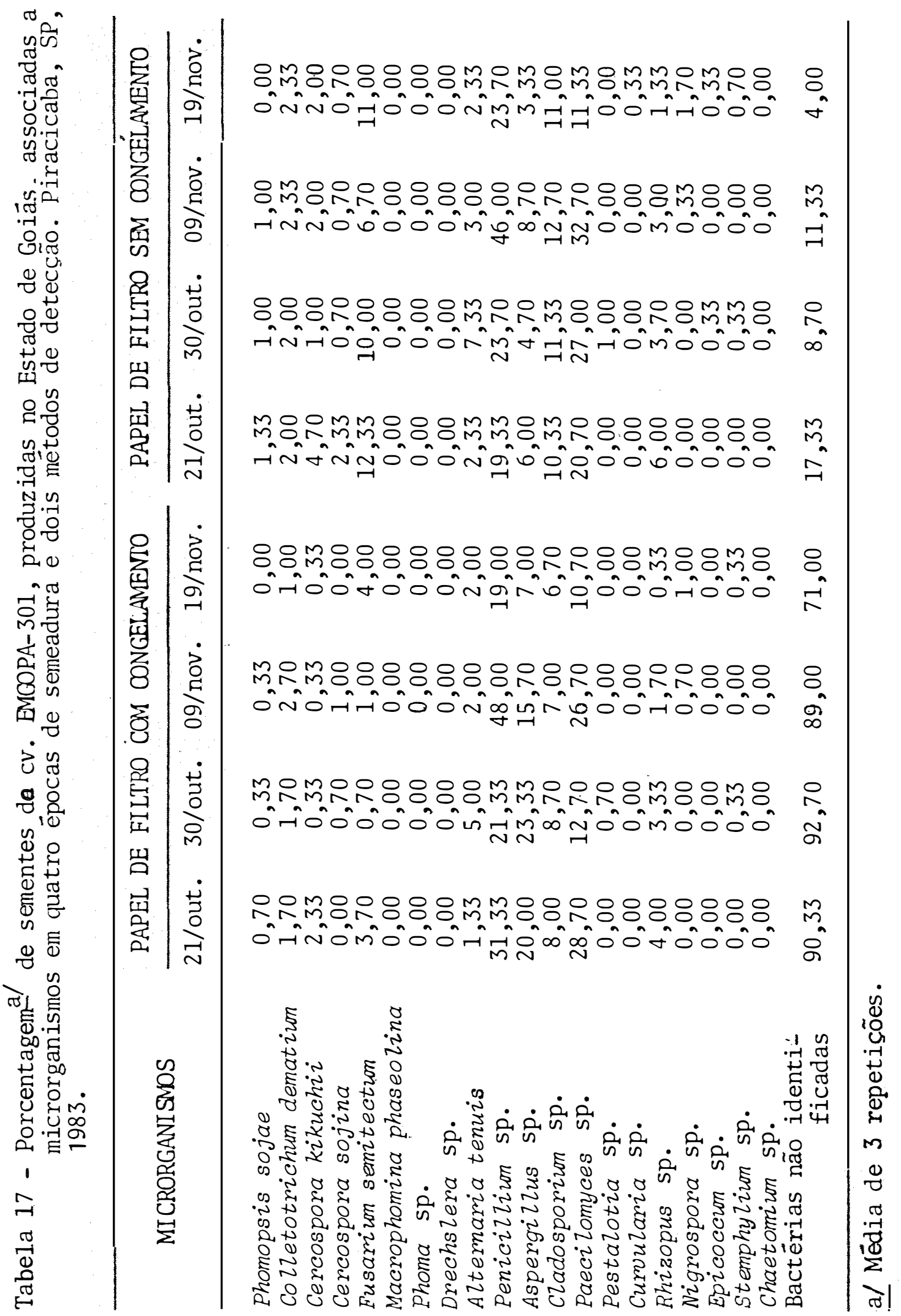




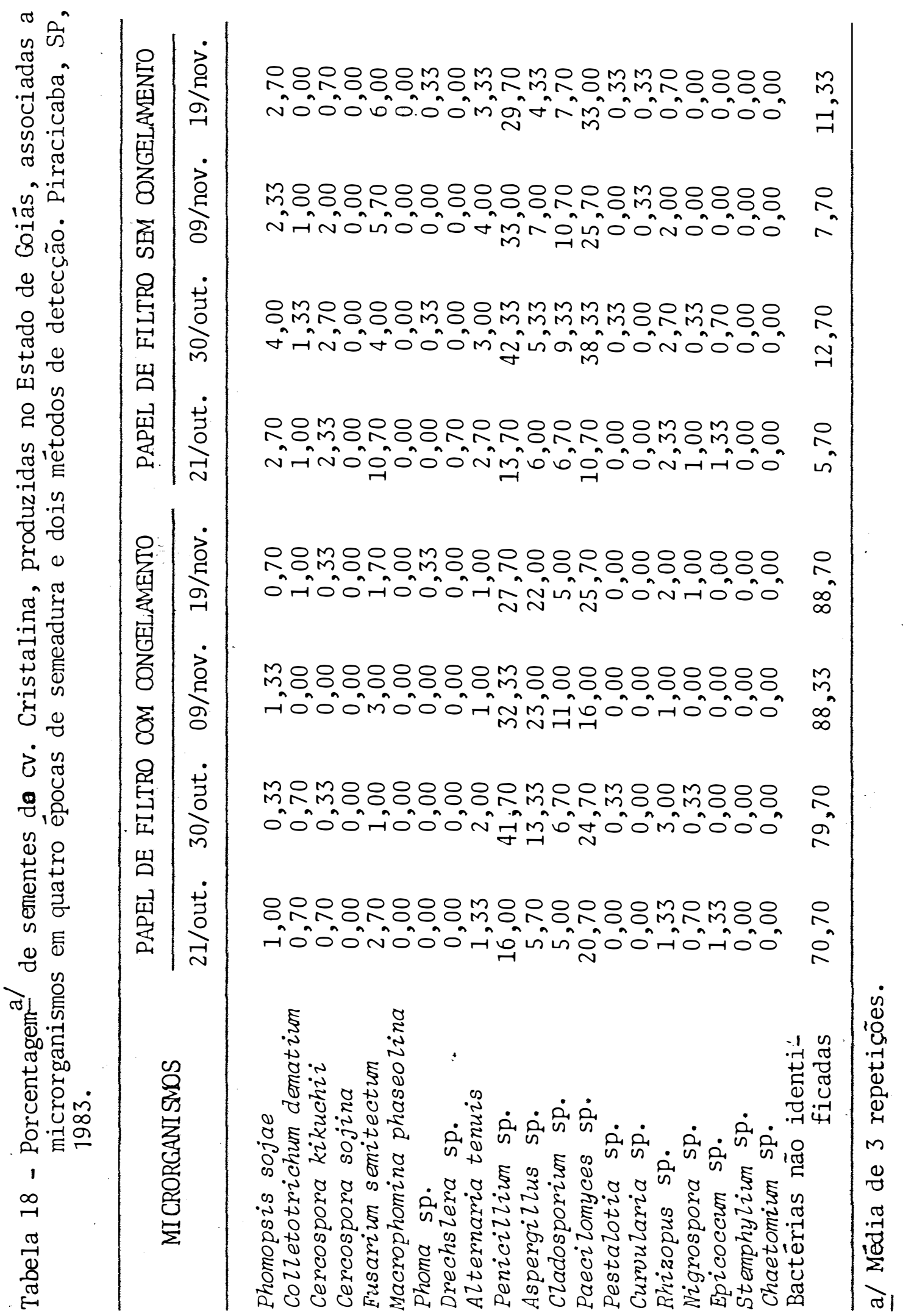




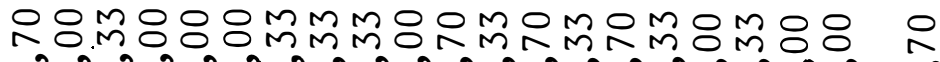

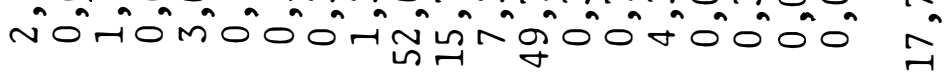

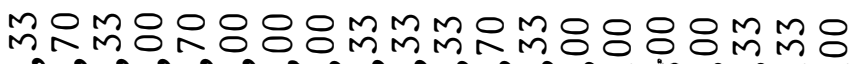

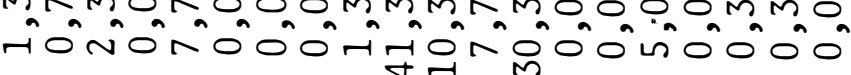
$\stackrel{m}{=}$

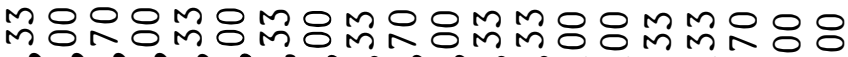

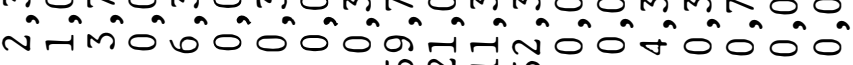

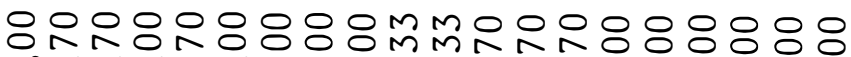

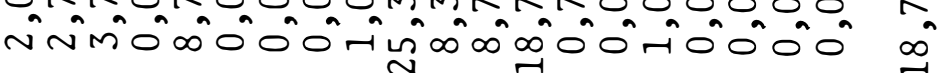

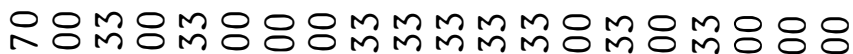

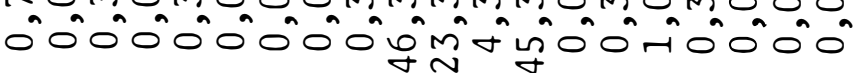

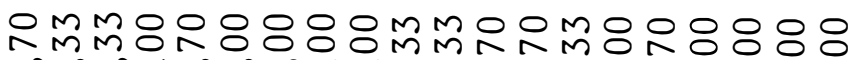

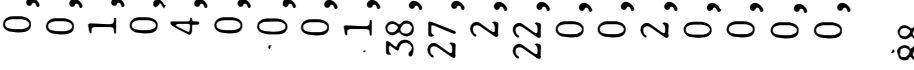

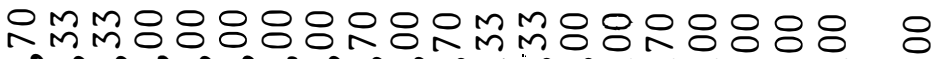

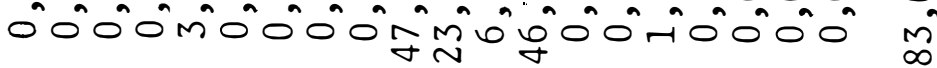

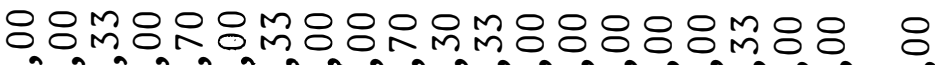
กัก0ก

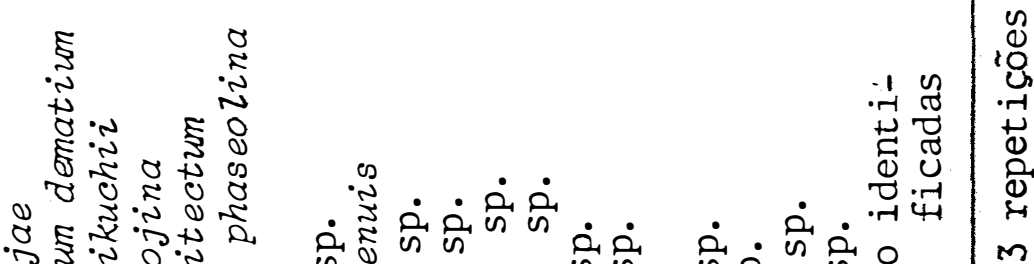

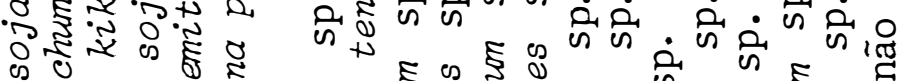

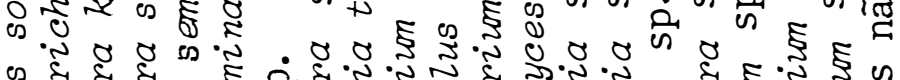
का को

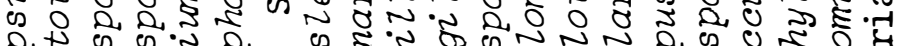

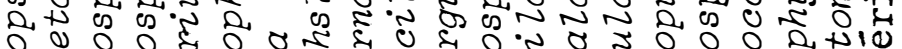

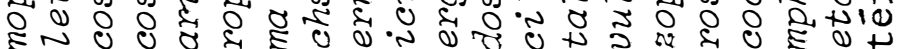
0,4
0

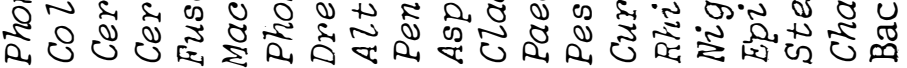


Anälise mais detalhada sobre o efeito do genótipo e da época de semeadura sobre a incidência de microrganismos associados a sementes de soja foi realizado apenas para os organismos reconhecidamente patogêni$\cos$ e, portanto, de maior importância na sanidade de se mentes. Estas anālises estão apresentadas nos itens 4.5 a 4.8 .

4.5 - Efeito do Genótipo e Epocas de Semeadura na Incidência de Phomopsis sojae em Sementes de Soja

Os resultados obtidos para este parâmetro säo apresentados, resumidamente, na Tabela 20. Atra vês da anảlise de variância foi possível detectar o efe to estatisticamente significativo para cultivares; não houve efeito significativo para épocas de semeadura e para interação cultivares $x$ épocas de semeadura. Entre os culti vares analisadas, Doko e EMGOPA-301 foram os que apresentaram menores frequências de $P$. sojae em suas sementes $\left(0,77-1,00^{\circ}\right)$; em contraste, o cv. UFV-1 apresentou a mais alta frequência de sementes com o patógeno $(5,92 \%)$. 
Tabela 20 - Efeito do Genótipo e da Epoca de Semeadura fre quência $\left(\begin{array}{c}0 \\ 0\end{array}\right)$ de Phomopsis sojae em sementes de soja [Glycine $\max$ (L.) Merril1], no Esta do de Goiảs. Piracicaba, SP, 1983.

\begin{tabular}{|c|c|c|c|c|c|}
\hline \multirow{2}{*}{ CULTIVARES } & \multicolumn{4}{|c|}{ EPOCAS DE SEMEADURA } & \multirow{2}{*}{ MEDIA } \\
\hline & 21/out. & 30/out. & 09/nov. & 19/nov. & \\
\hline Doko & 1,00 & 0,70 & 0,70 & 0,70 & $0,77 \mathrm{a}$ \\
\hline FMGOPA-301 & 1,33 & 1,00 & 1,70 & 0,00 & $1,00 \mathrm{a}$ \\
\hline IAC-2 & 1,00 & 3,33 & 1,33 & 1,00 & $1,66 a b$ \\
\hline Bossier & 2,00 & 1,00 & 4,00 & 0,70 & $-1,92 \mathrm{ab}$ \\
\hline Paraná & 1,70 & $2,00^{\circ}$ & 1,33 & 3,00 & $2,00 a b c$ \\
\hline Tropical & 1,70 & 1,00 & 3,70 & 1,70 & $2,02 a b c$ \\
\hline Paranagoiana & 2,00 & 2,33 & 1,70 & 2,33 & $2,09 a b c$ \\
\hline Santa Rosa & 2,33 & 3,33 & 1,00 & 2,33 & $2,25 a b c$ \\
\hline IAC- 8 & 3,00 & 1,70 & 2,00 & 4,33 & $2,76 a b c$ \\
\hline Cristalina & 2,70 & 3,00 & 4,00 & 3,33 & $3,26 a b c$ \\
\hline Numbaira & 3,70 & 4,33 & 3,33 & 6,00 & $4,34 \mathrm{bc}$ \\
\hline IAC-6 & 4,70 & 4,00 & 5,33 & 4,33 & $4,60 \mathrm{bc}$ \\
\hline IAC-7 & 5,00 & 3,70 & 5,00 & 6,00 & $4,92 \mathrm{bc}$ \\
\hline UFV-1 & 3,00 & 5,00 & 9,00 & 6,70 & $5,92 \quad c$ \\
\hline Mëdia & $2,50 \mathrm{a}$ & $2,60 a$ & $3,15 a$ & $3,03 a$ & \\
\hline
\end{tabular}

a/ Média de 3 repetições de dados obtidos pelo método do papel de filtro sem congelamento.

b/ Médias seguidas da mesma letra não diferiram significativamente entre si pelo teste Tukey ao nível de $5^{\circ}$ de probabilidade. 
4.6 - Efeito do Genótipo e da Enoca de Semeadurána Incidência de Colletotrichum dematium var. truncata em sementes de soja

Os resultados obtidos para este parâmetro são apresentados, resumidamente, na Tabela 21. Atra vés da análise de variância foi possível detectar efeito estatisticamente significativo para cultivares; não houve efeito significativo para épocas de semeadura e para a interação cultivares $x$ épocas de semeadura. Entre - os cultivares analisadas, Bossier e Paranä foram o.s que apresentaram menores frequências de $C$. dematium var. trunca ta em sementes $(0,16-0,26 \%)$; em contraste, o cv. UFV-1 apresentou a mais alta frequência de sementes com o patógeno $(3,09 \%)$.

4.7 - Efeito do Genótipo e Época de Semeadura na Incidência de Cercospora kikuchii em Sementes de Soja

Os resultados obtidos para este parâmetro são apresentados, resumidamente, na Tabela 22. Atra vês da análise de variância, verificou-se que houve efeito significativo para cultivares; não houve efeito significativo para épocas de semeadura e para a interação 
Tabela 21 - Efeito do genótipo e da época de semeadura na fre quência $\left(\frac{0}{0}\right)$ de colletotrichum dematium var. truncata em sementes de sojà [Glycine max (L.) Merrill], no Estado de Goiās. Piracica ba, SP, 1983.

\begin{tabular}{|c|c|c|c|c|c|}
\hline \multirow{2}{*}{ CULTIVARES } & \multicolumn{4}{|c|}{ EPOCA DE SEMEADURA a / } & \multirow{2}{*}{ MEDIA ${ }^{a /}$} \\
\hline & 21/out. & 30/out. & 09/nov. & 18/nov & \\
\hline Bessier & 0,33 & 0,33 & 0,00 & 0,00 & $0,16 \mathrm{a}$ \\
\hline Parană & 0,33 & 0,70 & 0,00 & 0,00 & $0,26 a$ \\
\hline Doko & 0,00 & 1,33 & 0,70 & 0,00 & $0,51 \mathrm{ab}$ \\
\hline IAC- 6 & 0,70 & 0,33 & 1,00 & 0,00 & $0,57 \mathrm{ab}$ \\
\hline Cristalina & 1,33 & 1,00 & 0,00 & 0,33 & $0,66 a b$ \\
\hline Santa Rosa & 1,33 & 0,70 & 0,33 & 0,33 & $0,67 \mathrm{ab}$ \\
\hline Paranagoiana & 2,70 & 1,00 & $0,7.0$ & 0,00 & $1,10 \mathrm{ab}$ \\
\hline Numbaira & 1,33 & 0,33 & 1,33 & 1,70 & $1,17 \mathrm{ab}$ \\
\hline Tropical & 1,00 & 2,33 & 0,33 & 1,33 & $1,25 \mathrm{ab}$ \\
\hline IAC-2 & 1,00 & 0,70 & 2,00 & 2,00 & $1,42 \mathrm{ab}$ \\
\hline IAC- 8 & 0,70 & 0,33 & 1,33 & 3,33 & $1,42 \mathrm{ab}$ \\
\hline EMGOPA- 301 & 2,00 & 2,00 & 2,00 & 2,33 & $2,08 \mathrm{ab}$ \\
\hline IAC- 7 & 0,33 & 2,00 & 5,33 & 1,70 & $2,34 \mathrm{ab}$ \\
\hline UFV-1 & 2,33 & 0,33 & 5,70 & 4,00 & $3,09 \mathrm{~b}$ \\
\hline Médiabl & $1,10 \mathrm{a}$ & $0,96 a$ & $1,50 \mathrm{a}$ & $1,22 \mathrm{a}$ & \\
\hline
\end{tabular}

a/ Média de 3 repetições de dados obtidos pelo método do papel de filtro sem congelamento.

b/ Médias seguidas da mesma letra não diferiram significativamente entre si pelo teste Tukey ao nível de 5\% de probabilidade. 
Tabela 22 - Efeito do genōtipo e da época de semeadura na fre quência de Cercospora kikuchii em sementes de soja [Grycine $\max$ (L.) Merril1], no Esta do de Goiäs. Piracicaba, SP, 1983.

\begin{tabular}{|c|c|c|c|c|c|}
\hline \multirow{2}{*}{ CULTIVARES } & \multicolumn{4}{|c|}{ EPOCA DE SEMEADURA a/ } & \multirow{2}{*}{ MEDIA } \\
\hline & 21/out. & 30/out. & 09/nov. & 19/nov. & \\
\hline IAC- 8 & 0,70 & 2,00 & 0,33 & 1,70 & $1,18 \mathrm{a}$ \\
\hline Numbaira & 1,70 & 1,33 & 0,70 & 1,00 & $1,18 \mathrm{a}$ \\
\hline IAC-6 & 0,33 & 1,70 & 0,70 & 2,00 & $1,18 \mathrm{a}$ \\
\hline Bossier & 1,70 & 2,70 & 1,33 & 1,70 & $1,85 \mathrm{a}$ \\
\hline Cristalina & 2,33 & 2,70 & 2,00 & 0,70 & $1,93 a$ \\
\hline IAC-2 & 1,33 & 1,33 & 3,00 & 3,33 & $2,25 a$ \\
\hline Tropical & 2,00 & 2,70 & 3,00 & 1,33 & $2,26 a$ \\
\hline Paranä & 1,70 & 3,00 & 2,33 & 2,33 & $2,34 a$ \\
\hline Santa Rosa & 2,00 & 1,33 & 2,33 & 3,70 & $2,34 a$ \\
\hline IAC-7 & 2,70 & 3,00 & 2,33 & 1,70 & $2,43 a$ \\
\hline UFV-1 & 3,70 & 1,00 & 3,00 & 4,00 & $2,92 \mathrm{a}$ \\
\hline Doko & 3,33 & 2,33 & 3,00 & 4,00 & $3,16 a$ \\
\hline Paranagoiana & 3,70 & 2,33 & 3,70 & 3,00 & $3,18 \mathrm{a}$ \\
\hline EMGOPA-301 & 4,70 & 3,33 & 2,70 & 2,70 & $3,36 a$ \\
\hline Médial & $2,28 \mathrm{a}$ & $2,20 \mathrm{a}$ & $2,17 \mathrm{a}$ & $2,37 a$ & \\
\hline
\end{tabular}

a/ Média de 3 repetições de dados obtidos pelo método do papel de filtro sem congelamento.

b/ Médias seguidas da mesma letra não diferiram significativamente entre si pelo teste Tukey ao nível de 5\% de probabilidade. 
cultivares $x$ épocas de semeadura. Embora o teste $F$ tenha indicado efeito significativo para cultivares, quando os mesmos dados foram submetidos ao teste Tukey, ao nível de 5\% de probabilidade, não foi possível se detectar diferenças entre os cultivares de soja.

4.8 - Efeito do Genótipo e da Epoca de Semeadura na Incidência de Fusarium semitectum em Sementes de Soja

Os resultados obtidos para este parâmetro são apresentados, resumidamente, na Tabela 23. At ra vês da análise de variância foi possível detectar efeito estatisticamente significativo para cultivares e para interação cultivares $x$ épocas de semeadura; não houve efeito estatístico para épocas de semeadura. Entre os cultivares analisadas, o Tropical foi a que apresentou menor frequência $(5,76 \%)$ de $F$. semitectum em suas sementes; em contraste, o cv. IAC- 2 apresentou 0 ; mais alta frequência $(21,92 \%)$ de sementes com o patógeno.

A interação significativa entre cultivares e épocas de semeadura indicou que o comportamento das cultivares depende das épocas de semeadura, assim como o efeito das épocas de semeadura na frequência de sementes 
com F. semitectum depende da cultivar considerada. Quan to ao efeito época de semeadura no ordenamento das cultivares, segundo a frequência de sementes associadas ao patógeno, pode-se verificar que, para a primeira época de semeadura, o cultivar com menor frequência de associação foi o Tropical, seguida pel Paraná; em contraste, a maior frequência foi verificada em IAC-2. Já na segun da época de semeadura, a menor frequência foi apresentada pela Cristalina e a maior pel IAC-6. Na terceira época o cv. Doko apresentou a menor frequência de associação e o cv. IAC-2 novamente a maior. Já na quarta época, o cv. Paranagoiana foi o que apresentou a menor frequência,en quanto o cv. Santa Rosa apresentou a maior.

Quanto à influência do genötipo no ordenamento do efeito das épocas de semeadura na incidência de F. semitectum, pode-se comparar os cvs. Santa Rosa com Paranagoiana; para o primeiro cultivar, a menor incidên cia ocorreu na terceira época de semeadura:maior na quarta. Já para o cv. Paranagoiana, a menor incidência ocorreu na quarta época e a maior na primeira. Interações semelhantes foram detectadas entre diversas outras cultivares. 
Tabela 23 - Efeito do genótipo e da época de semeadura na fre quência $\left(\begin{array}{l}0 \\ 0\end{array}\right)$ de Fusarium semitectum em semen tes de soja [Glycine max (L.) Merril1), no Estado de Goiās. Piracicaba, SP, 1983.

\begin{tabular}{|c|c|c|c|c|c|}
\hline \multirow{2}{*}{ CULT IVARES } & \multicolumn{4}{|c|}{ EPOCAS DE SEMEADURA ${ }^{a /}$} & \multirow{2}{*}{ MEDIA b/ } \\
\hline & 21/out. & 30/out. & 09/nov. & 19/nov. & \\
\hline Tropical & 4,00 & 5,00 & 6,70 & 7,33 & $5,76 a$ \\
\hline Paranagoiana & 8,70 & 6,33 & 7,70 & 3,00 & $6,43 a b$ \\
\hline Cristalina & 10,70 & 4,00 & 5,70 & 6,70 & $6,78 \mathrm{ab}$ \\
\hline Doko & 14,70 & 8,33 & 2,70 & 4,70 & $7,61 \mathrm{ab}$ \\
\hline Paranà & 8,33 & 8,70 & 12,70 & 8,00 & $9,43 \mathrm{abc}$ \\
\hline EMOOPA-301 & 12,33 & 10,00 & 6,70 & 11,00 & $10,00 \mathrm{abc}$ \\
\hline Numbaira & 14,00 & 9,00 & 10,70 & 13,00 & $11,67 \mathrm{abcd}$ \\
\hline Bossier & 12,00 & 12,70 & 12,33 & 10,70 & 11,93 bcde \\
\hline UFV-1 & 14,70 & 15,00 & 15,70 & 12,00 & 14,35 cdef \\
\hline IAC-6 & 11,70 & 22,33 & 17,00 & 7,00 & 14,50 cdef \\
\hline IAC-7 & 9,00 & 17,70 & 17,33 & 16,00 & 15,00 cdef \\
\hline Santa Rosa & 15,00 & 18,70 & 13,00 & 28,70 & 18,85 \\
\hline IAC- 8 & 15,33 & 21,33 & 24,70 & 17,33 & 19,70 \\
\hline IAC-2 & 18,00 & 18,00 & 30,00 & 21,70 & 21,92 \\
\hline Médiabl & $12,03 a$ & $12,65 a$ & $13,06 a$ & $11,94 \mathrm{a}$ & \\
\hline
\end{tabular}

a/ Média de 3 repetições de dados obtidos pelo método do papel de filtro sem congelamento.

b/ Médias seguidas da mesma letra não diferiram significativamente entre si pelo teste Tukey ao nivel de 5\% de probabilidade. 


\section{DISCUSSÃO}

As diferenças detectadas no presente tra balho, entre genótipos de soja, épocas de semeadura e méto dos de detecção, quanto à incidência dos microrganismos associados a sementes (Tabelas 6 a 19), particularmente os patogênicos (Tabelas 20 a 23 ), provavelmente não tenham sido mais acentuadas devido ao efeito do armazenamento das sementes durante cerca de oito meses em laboratörio. O período e condições em que as sementes foram submetidas ao armazenamento deve ter sido suficiente pa ra diminuir significativamente as frequências de micror ganismos associados a sementes de todas as amostras ana lisadas, conforme conclusões apresentadas por diversos autores (HENNING et alii, 1980; SHOEN e SCHULB, 1980; 
COSTA et alii, 1981; WETZEL et alii, 1983; NUNES Jr. e MENTEN, 1984). Entretanto, os dados obtidos foram suficientes para discriminar as variáveis cọnsideradas no presente trabalho, conforme demonstrado nos itens 4.4 a 4.7 .

5.1 - Metodologia Para Detecção de Microrganismos As sociados a Sementes de Soja

A literatura sobre testes de sanidade de sementes é bastante controvertida quanto aos métodos mais adequados para serem empregados em levantamentos de microrganismos associados a sementes. Mesmo se considerando um ünico sistema patógeno/hospedeiro, são escassas as recomendações sobre o melhor mëtodo, que sejam aceitas internacionalmente e que possa ser utilizado co mo rotina. Daí, o grande esforço que se vem realizando na tentativa de alcançar este objetivo, atravês dos tes tes internacionais (YORINORI et alii, 1979).

No caso particular de sementes de soja, os mëtodos mais utilizados são o plaqueamento em ägar e o plaqueamento em papel de filtro umedecido com solução de 2,4-D (ELLIS, 1974; SINCLAIR e DHINGRA, 1975; SONEGO e BOLKAN, 1978; FULCO et alii, 1979; YORINORI et alii, 
1979 e DHINGRA et alii, 1979). O método do ägar, apesar de facilitar a identificação dos microrganismos, jã que se baseia na morfologia das colônias, apresenta como grandes inconvenientes o mascaramento de organismos com baixa taxa de desenvolvimento e o custo elevado do meio de cultura (matéria prima e preparação). O método do pa pel de filtro é o mais simples e econômico; apresenta co mo limitação a necessidade do exame sob o microscópio es tereoscópico de cada semente, para identificação dos mi crorganismos a ela associados. Entretanto, è mais econô mico em termos de materiais e, em geral, proporciona a recuperação de um amplo expectro de microrganismos, mes mo aqueles de desenvolvimento mais lento.

As variações do método do papel de filtro, através do congelamento ou 2,4-D, visam exclusivamente facilitar a detecção e identificação dos microrga nismos e inibir a germinação das sementes. As vantagens do método do congelamento são, principalmente, a ausência de uma possível interferência do 2,4-D sobre o desenvol vimento dos microrganismos e a não necessidade de manipulação de uma substância química.

Pelos resultados obtidos no presente tra balho (Tabelas 6 a 19) foi possivel verificar que o método do papel de filtro foi mais conveniente que o méto 
do do papel de filtro com congelamento; isto porque pro porcionou uma maior recuperação dos microrganismos de maior importância patogênica para a cultura da soja e tambëm sua identificação mais segura, jà que as sementes submetidas ao congelamento apresentaram alta incidência de bactérias não identificadas, que dificultaram as avaliações. E possível que esta alta incidência de bactérias, provavelmente saprofíticas, seja consequência do baixo vigor das sementes, devido ao prolongado armazenamento sob condições ambientes. Tambëm para os fungos normalmente referidos como saprófitas, o método do papel de filtro sem congelamento proporcionou uma maior recuperação.

Entretanto, deve-se salientar que uma das vantagens do congelamento das sementes, que é a ini bição da germinação, não teve efeito no presente traba1ho. As sementes submetidas aos testes de sanidade,após 8 meses de armazenamento sob condições ambientes de laboratório, apresentaram uma germinação muito baixa. Assim, as sementes plaqueadas em papel de filtro, sem con gelamento, não apresentaram uma germinação que prejudicasse o desenvolvimento dos testes durante a incubação ou a detecção e identificação dos microrganismos. 
Desta maneira, embora os presentes resul tados indiquem o método do papel de filtro sem congelamento como o mais adequado para avaliação da sanidade de semente de soja, é necessārio que estes dados sejam confirmados empregando-se sementes mais novas, com maior vigor, armazenadas sob condições adequadas. Na literatŭ ra existem relatos sobre as vantagens do método do papel de filtro com congelamento para sementes de milho, sorgo, trigo, mamona e girassol (MATHUR et alii, 1975; LASCA et alii, 1983; BARROS et alii, 1984 e MENDES et a zii, 1984).

5.2 - Efeito do Genótipo na Sanidade de Sementes de Soj a

Cultivares podem apresentar diferentes $\underline{n} \mathbf{i}$ veis de resistência a diversos patógenos. Considerando-se um microrganismo que se desenvolva em värios órgãos ou estruturas da planta hospedeira, a avaliação da resistência pode ser mensurada através da severidade dos sintomas nas partes em que a exteriorização da coloniza ção seja mais evidente. Normalmente se avalia a reação de cultivares a patógenos através da área foliar afetada ou da intensidade de sintomas nas raízes, hastes, fru tos, etc. 
A resistência de um cultivar pode ser avaliạda através da frequência de associação de determi nado microrganismo com as suas sementes. Um cultivar cujas sementes apresentaram menor frequência de associa ção com um determinado microrganismo pode indicar que a planta que produziu estas sementes apresentou uma maior resistência ao patógeno sob condições de campo, sugerin do uma correlação entre reação da planta mãe e qualidade sanitāria das sementes. Entretanto, é tambëm possível que existam mecanismos especificos responsảveis pela re sistência de sementes, ou seja, a planta mãe pode apresentar alto nível de suscetibilidade mas não haver trans mıssão do patógeno para as sementes.

No presente trabalho avaliou-se somente a sanidade das sementes, não se podendo fazer correlações com a reação dos 14 cultivares, sob condições de campo, aos diferentes patótenos da soja. Foi verificado que houve diferença entre cultivares quanto à incidência da maior parte dos patógenos (ou sintomas) considerados (Tabelas 3 a 5 e 20 a 23 ). Na literatura existem diversas referências sobre o efeito do genótipo na inci dência de microrganismos em sementes de diversas espēcies cultivadas (FULCO et alii, 1977; MENEZES et alii, 1979 ; MENTEN et alii, 1980; MENEZES, 1981; LIMA et alii, 
1982; BARROS et alii, 1983; FERREIRA E MENEZES et ali $i$, 1983; NASSER et alii, 1983 e SOAVE et alii, 1983).

Quanto à incidência de mancha pürpura, sabe-se que existe uma ampla variação na frequência de sementes com sintomas entre os cultivares, conforme resultados de pesquisas realizadas por MURAKISHI (1951), DIAZ-POLANCO (1966), ISSA e MASCARENHAS (1971), WILCOX e ABNEY (1973), GOMES (1975), DHINGRA et alii (1978) e FRANCA NETO et alii (1983). No presente trabalho foi pos sível discriminar os 14 cultivares estudadas em diferen tes níveis de suscetibilidade, conforme demonstrado na Tabela 3. A cultivar que mais se destacou no presente ex perimento, por apresentar a mais baixa frequência de se mentes com mancha pürpura, foi UFV-1 $(0,25 \%)$, enquanto Paranagoiana apresentou a mais. alta frequência $(4,70 \%)$. Entretanto, outros 9 cultivares não diferiram estatisti camente de UFV-1; somente foram significativamente inferiores os cvs. EMGOPA-301, Bossier e Paraná. Estes resultados não puderam ser comparados com outros relatos na literatura, jâ que os trabalhos disponíveis não incluíram os cultivares promissoras para o Estadode Goiäs.

A frequência de mancha café em sementes de soja tambèm é afetada pelo genótipo; COSTA et alii (1970), HORN et alii (1970), LIMA NETO (1974), PHATAK 
(1974), COSTA e LIMA NETO (1974), ALMEIDA E MIRANDA(1978), LAM-SANCHEZ e YUYAMA (1979) e LIMA NETO (1979), referiram-se ao assunto, demonstrando a ampla variação entre cultivares quando a percentagem de sementes apresen tando os sintomas. No presente trabalho foi possivel ve rificar que os cultivares mostraram diferenças estatísticas quanto à porcentagem de sementes com sintomas (Ta bela 4); entretanto, de uma maneira geral, a incidência de mancha café foi baixa. Os cultivares Paraná, Numbaira, IAC-6 e Paranagoiana não apresentaram sementes com sintomas;outros seis crs., embora com algumas sementes com mancha café, não diferiram dos quatro anteriores.Apenas os cultivares Bassier, IAC- 8 , UFV-1 e Santa Rosa (esta com 0,21\% de sementes com mancha café) foram significativamente inferiores aos materiais completamente resistentes.

A mancha de levedura em sementes de soja tem sido relativamente pouco estudada; HEINRICHS et ali $i$ (1976) referem-se ao problema, demonstrando a variação em porcentagem de sementes com sintomas da doença entre diversos cultivares de soja. Através dos dados apresentados na Tabela 5 é possível verificar que, sob as presentes condições experimentais, houve uma acentuada diferença quanto à frequência de sementes com mancha de 
levedura entre os 14 cvs. consideradas. A IAC-6 foi o. cultivar que mais se destacou $(0,14 \%$ de sementes com tomas); os outros 10 cultivares com incidências entre 0,19 e 0,78\% não diferiram significativamente de IAC-6. Apenas os cvs. Bossier $(0,96 \%)$, Paranagoiana $(1,30 \%)$ e Paranā $(2,62 \%)$ diferiram dos demais e também entre si. Quanto à frequência de $P$. sojae associada a sementes de soja, a literatura revela a existência de uma ampla variação no nível de resistência apresenta do por diferentes cultivares (PETERSON e STRELECKI,1965; WILOOX et alii, 1974; BOLKAN e CUPERTINO, 1976; DHINGRA et alii, 1978, 1979; GOMES et alii, 1982, 1983). No pre sente trabalho foi possível discriminar os 14 cultivares estudadas em distintos níveis de suscetibilidade, conforme dados apresentados na. Tabela 20. O.s cultivares que mais se destacaram foram Doko e EMGOPA-301, por apresentarem 0,77 e $1,00 \%$ de sementes com $P$. sojae. Por outro lado, o cv. UFV-1 apresentou o mais alto índice de sementes com o patógeno $(5,92 \%)$. Os demais cultivares apresentaram incidências entre os dois extremos. Referente à incidência de $C$. , dematium var. truncata em sementes de soja, diversos autores têm relatado o diferente comportamento de cultivares quanto à incidência do patógeno em suas sementes (KILPATRICK e 
HARTWIG, 1955; FRENHANI, 1969; DHINGRA e SILVA, 1978; DHINGRA et alii, 1978, 1979; GOMES et alii, 1982, 1983). No presente estudo, foram detectadas diferenças entre os 14 cultivares consideradas. Os cvs. Bossier e Paraná, com 0,16 e 0,26\%, respectivamente, de sementes associadas ao patógenos, foram os que mais se destacaram, enquanto o cv. UFV-1, com 3,09\% de incidência foi o que apresentou o maior indice de sementes com $C$. dematium var. truncata (Tabela 21).

Quanto à incidência de C. kikuchii em se mentes de soja, a literatura se refere ao comportamento diferencial observado entre divers s cultivares (MURAKI SHI , 1951; DIAZ-POLANCO, 1966; WILCOX e ABNEY, . 1973; FRANÇA NETO et alii, 1983; YORINORI e SINCLAIR, 1983). Entretanto, no presente experimento não foi possível de tectar diferenças significativas entre os cultivares analisados (Tabela 22). Deve-se ressaltar que foi possivel discriminar os 14 cultivares quanto à frequência de sementes com sintomas causados por C. kikuchii (mancha pürpura), conforme dados apresentados na Tabela 3. Esta aparente incoerência pode ser explicada por se tratarem de eventos distintos, ou seja, uma semente pode estar infectada por $C$. kikuchii e não mostrar sintomas, ou uma semente com sintomas típicos de mancha pürpura pode não 
apresentar o patógeno viāvel para ser recuperado durante um teste de sanidade atravês de incubação da semente, conforme demonstrado por NUNES Jr. e MENTEN (1984). Entretanto, esforços devem ser desenvolvidos no sentido de se verificar a correlação existente entre sintomas nas sementes e ocorrência do patógeno associado à semente, que deve ser o responsável pela transmissão e infecção da planta proveniente da semente infectada.

Referente à incidência de $F$. semitectum em sementes de soja, existem dados indicando que os cul tivares de soja podem apresentar comportamentos distintos (BOLKAN et alii, 1976 ; DHINGRA e SILVA, 1978; DHINGRA e MUCHOVEJ, 1979 e DHINGRA et alii, 1978, 1979). Os dados obtidos no presente trabalho (Tabela 23) permitiram a distinção dos cultivares em diferentes níveis de resistência ao patógeno. $0 \mathrm{cv}$. Tropical foi a que apresentou a mais baixa frequência de associação com $F$. semitectum $(5,76 \%)$, ao passo que o cv. IAC- 2 apresentou a mais alto $(21,92 \%)$. Entretanto, outros seis cultivares não diferiram significativamente do $c v$. Tropical.

Uma anảlise conjunta, visando demonstrar o efeito do genótipo na sanidade de sementes de soja pró duzidas no Estado de Goiās, no ano agrícola 1981/82 è apresentada na Tabela 24. 


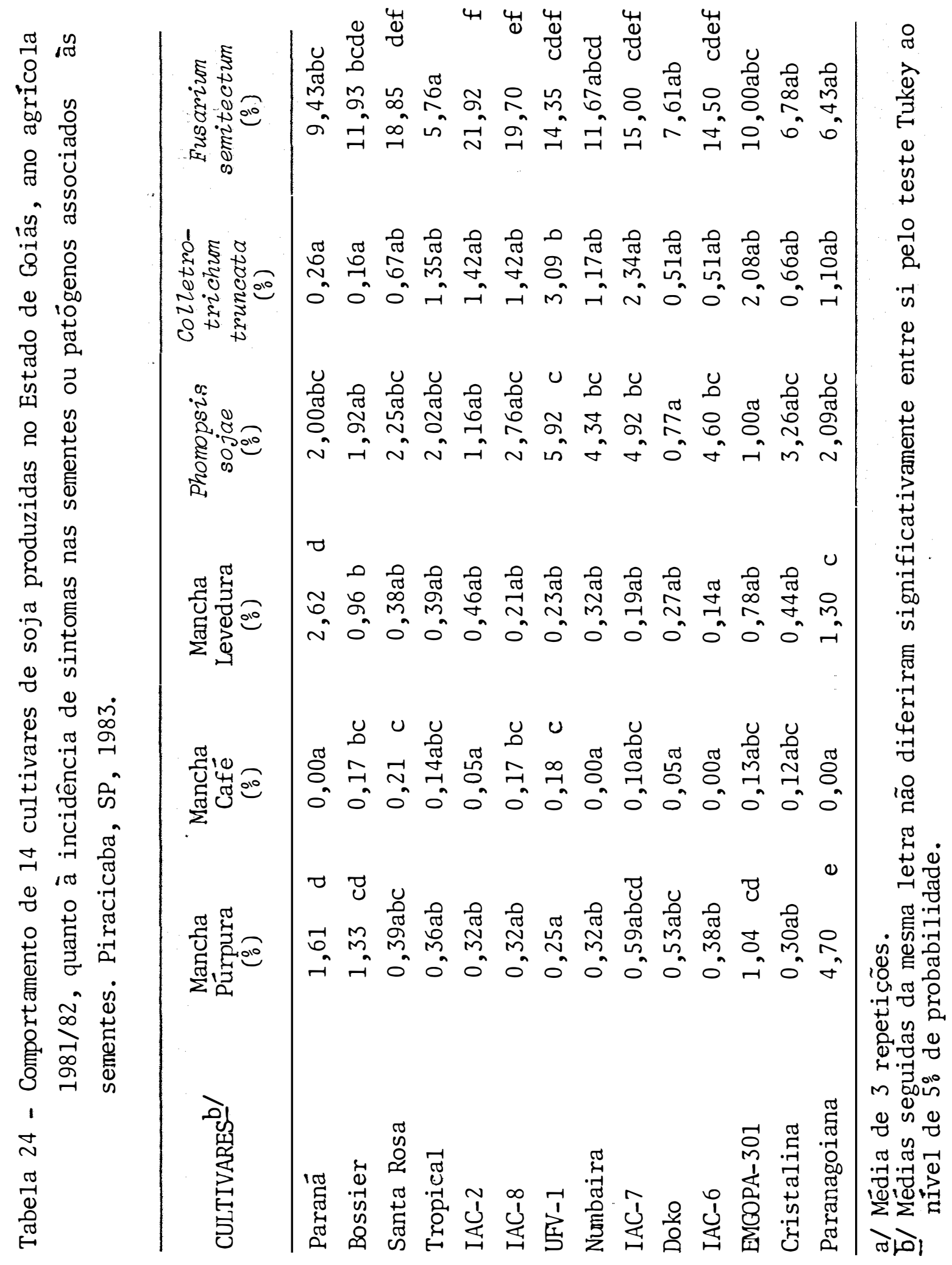


Atrạếs das médias obtidas para os carac teres agronômicos apresentados nos Apêndices 2 a 7 , verificou-se que os cultivares em estudo tiveram comporta mento diferente para os seguintes parâmetros avaliados: duração do ciclo, rendimento, altura da planta, indice de acamamento, altura de inserção das 1 ạs vagens e peso de 1000 sementes.

Quanto à duração do ciclo, a literatura revela a existência de uma variação apresentada por diferentes cultivares (FEASTER, 1949; ABEL, 1961; CARTER, 1974 ; COSTA, 1975 ; CONSTABLE, 1977 ; ROLIM, 1977 ; GUIMARAES et alii, 1978; MONTEIRO et alii, 1980; COSTA et alii, 1984). No presente trabatho foi possivel diferenciar os cultivares quanto à duração do ciclo, conforme Apêndice 2, Com exceção do cultivar Tropical, os outros se mantiveram dentro da média jâ obtida através de vārios anos de pesquisa no Estado de Goiás, conforme Tabe 1 a 2 .

Quanto à produção de sementes da soja, a literatura se refere ao comportamento diferencial observado entre diversos cultivares (FEASTER, 1949; DIMMOCK e WARREN, 1953; HARTWIG, 1954; SMITH, 1954; TORRIE e BRIGGS, 1955; COSTA, 1977 ; CONSTABLE, 1977; ROLIM, 19.77; MONTEIRO et alii, 1980; ABEL, 1981; NAKAGAWA, 1981 ; COSTA et alii, 1984; MARCOS FILHO et alii, 1984). No 
presente trabalho foi possível diferenciar os quatorze cultivares, conforme Apêndice 3. Os cultivares que mais se destacaram foram, Cristalina, UFV-1, Tropical, Numbaira, Paranagoiana e Santa Rosa.

Quanto aos indices de acamamento, diversos autores relataram o comportamento diferente de cultivares de soja (SANTOS, 1975; ROLIM, 1977; MONTEIRO et alii, 1980; COSTA et alii, 1984). Considerando 2,5, con forme SANTOS (1975), como o indice mäximo tolerável de acamamento, verificou-se através do Apêndice 4 que ... as mêdias dos quatorze cultivares não ultrapassaram este limite. Os menores indices foram obtidos pelos cultiva res Paranā, Bossier, Santa Rosa e UFV-1.

A altura e o vigor da planta de soja são de considerável importância, em consequência de possíveis efeitos sobre o rendimento, controle das ervas daninhas, acamamento e a colheita (SILVA et alii, 1970). Através dos dados obtidos no presente trabalho, apresen tados no Apêndice 5, pode-se verificar que os cultiva res tiveram comportamento diferentes. Os cultivares que mais se destacaram, foram Paranagoiana, Tropical, IAC-6 e IAC-2. A 1iteratura revela comportamento diferencial quanto a este parâmetro (SILVA et alii, 1970; SANTOS, 1975; ROLIM, 1977; MONTEIRO et alii, 1980; COSTA et alii, 1984). 
A altura de inserção das 1 ạs vagens é uma importante característica varietal nas regiões onde a soja é colhida mecanicamente (HARTWIG, 1973). Conforme SANTOS (1975), $10 \mathrm{~cm}^{-} \mathrm{e}$ a menor altura de inserçãodas 1ạs vagens favorável para a colheita mecanizada. A lite ratura revela a existência de uma variação apresentada por diferentes cultivares quanto a este parâmetro (HART WIG, 1973; SANTOS, 1975; ROLIM, 1977; MONTEIRO et alii, 1980; COSTA et alii, 1984). Os cultivares que mais se destacaram foram Tropical e Doko; entretanto, nenhum cultivar avaliado apresentou na média inserção das 1 ạs vagens inferior a $10 \mathrm{~cm}$.

Quanto ao peso de 1000 sementes, a literatura refere-se a existência de uma variação entre diferentes cultivares (FEASTER, 1949; SMITH, 1954; LEFFEL, 1965 ; NICHOLSON e SINClAIR, 1973; ROLIM, 1977; NAKAGAWA, 1981; COSTA et alii, 1984; MARCOS FILHO et alii, 1984). No presente trabalho foi possível diferenciar os cultivares; conforme demonstrado no Apêndice 7 . Os cultivares que mais se destacaram foram: Bossier, IAC-8, Doko e Paranagoiana. 
Estas sugestões devem ser confirmadas através de novos experimentos, incluindo outros parâmetros de grande importância agronômica como a resistência a doenças e pragas, tolerância à seca, toxicidade de alumínio, etc., resposta à adubação, fixação biológica de nitrogênio, e outras. Deve-se tambëm considerar a va riação em germinação e vigor entre as cultivares estuda das.

5.3 - Efeito da Epoca de Semeadura na Sanidade de Semen tes de Soja

A época de semeadura pode afetar a qualidade sanitäria das sementes. Considerando-se que a ocorrência e frequência de microrganismos, assim como a intensidade da doença que pode causar em plantas hospede $\underline{i}$ ras, depende das condições climáticas, a avaliação do efeito da época de semeadura pode ser mensurada atravês da severidade de sintomas exibidos. Este efeito pode ser avaliado através da frequência de associação de micror ganismos com as sementes. Uma certa época de semeadurar que apresente sementes com menor frequência de associação com microrganismos, pode indicar que a época não foi prō pícia para o desenvolvimento da doença na planta mãe ou 
que no período em que as sementes se desenvolveram não houve condições satisfatórias para o estabelecimento do microrganismo considerado, evitando ou minimizando a ta xa de transmissão da planta mãe para a semente.

No presente trabalho foi avaliada somente a sanidade das sementes, não se dispondo de dados so bre a severidade de doenças durante o período vegetativo dos experimentos. Foi verificado que houve diferença entre épocas de semeadura apenas para dois dos sete parâmetros indicadores da sanidade, analisados estatisticamente (Tabelas 3 e 5 ). Na literatura existem referências sobre o efeito da época de semeadura na incidência de microrganismos associados a sementes (KILPATRICK e HART WIG, 1955; NICHOLSON e SINCLAIR, 1973; WILCOX et a $i i i$, 1974 ; NAGJU, 1977, 1979; LAM-SÃNCHEZ e YUYAMA, 1979 ; DHINGRA et a $i i i, 1979 \mathrm{ab}$; WETZEL et alii, 1971; GOMES et alii, 1983).

Quanto à mancha pürpura em sementes de soja, há relatos sobre a variação na percentagem de sementes com sintomas em função da época de semeadura (NICHOLSON e SINCLAIR, 1973; NAGJU, 1977; GOMES et alii, $1982,1983)$. No presente trabalho foi possivel diferenciar as quatro épocas de semeadura consideradas, conforme demonstrado na Tabela 3. A época que mais, se destacou, 
por apresentar a mais baixa frequência de sementes com sintomas, foi a ültima época de semeadura. (19/novembro),com $0,75 \%$ de-sementes com mancha púrpura; a primeira época de semeadura apresentou $1,18 \%$, seguindo-se a segunda e terceira com 0,95 e 0,76\%, respectivamente. Estes resultados estão de acordo com a literatura citada anteriormen te, ou seja, houve uma redução na frequência de sementes com sintomas à medida em que retardou a semeadura. Hâ referências que a frequência de mancha cafê em sementes de soja também ê afetada pela época de semeadura (NICHOLSON e SINCLAIR, 1973; NAGJU, 1977,1979; LAM-SANCHEZ e YUYAMA, 1979). No presente trabalho não foi possivel detectar diferenças entre as épocas de semeaduraquanto à percentagem de sementes com sintomas (Tabe la 4). Estes dados diferem da literatura citada, onde hâ evidências de que semeaduras mais tardias proporcionaram diminuição na incidência de mancha pürpura em semen tes de soja.

Não foram encontrados relatos sobre mancha de levedura em sementes de soja sendo influenciada pela epoca de semeadura. Entretanto, de acordo com os dados da Tabela 5 , é possivel verificar que houve um acen tuado decréscimo na percentagem de sementes com sintomas à medida que se retardou a semeadura (de $1,26 \%$ na pri meira época de semeadura para 0,23\% na quarta). 
Referente à frequência de P. sojae associada a sementes de soja, há dados demonstrando que a epoca de semeadura fica a frequência da associação do patógeno com sementes (DHINGRA et alii, 1979; WETZEL et alii, 1981; GOMES et alii, 1982, 1983). Através dos dados apresentados na Tabela 20 pode-se verificar que épo ca de semeadura não afetaran significativamente a incidência de $P$. sojae em sementes de soja nas presentescon dições experimentais.

Quanto à incidência de $C$. dematitium var. truncata em sementes de soja, a literatura mostra resul tados conflitantes no que se refere ao efeito da época de semeadura. DHINGRA et alii (1979) citaram que não houve influência da epoca de semeadura na percentagem de sementes com o patógeno, o que não foi observado nos trabalhos de WILCOX et alii (1974), WETZEL et alii (1981), GOMES et alii (1982, 1983a, 1983b). Através dos dados obtidos no presente trabalho também não foi possível de tectar diferenças entre épocas de semeadura (Tabela 21).

Cercospora kikuchii também pode apresentar diferentes frequências de associação com sementes de soja em função da época de semeadura (NICHOLSON e SINCLAIR, 1973; WILCOX et alii, 1974; WETZEL et alii, 1981; GOMES et alii, 1982, 1983). Entretanto, DHINGRA et alii, 
(1979) não verificaram diferenças entre épocas de semea dura, com o que estão de acordo os dados obtidos no presente experimento, apresentados na Tabela 22 .

Referente à incidência de $F$. semitectum em sementes de soja, existem referências na literatura indicando o efeito da época de semeadura na frequência de sementes associadas ao patógeno (DHINGRA et alii, 1979; WETZEL et alii, 1981; GOMES et alii, 1982, 1983). Entre tanto, os resultados obtidos no presente trabalho não permitiram a discriminação das épocas de semeadura, confor me demonstrado na Tabela 23.

Embora não tenham sido submetidos à anālise estatística, resultados exibidos nas Tabelas 6 a 19 indicaram que a frequência de microrganismos saprófí tos e bactérias não identificadas associados às sementes podem ser influencida pela ëpoca de semeadura.. Resulta dos concordantes foram obtidos por WILCOX et alii (1974), DHINGRA et alii (1979), WETZEL et alii (1981) e GOMES et alii (1982, 1983a, 1983b).

Através das médias obtidas para os carac teres agronômicos apresentados nos Apêndices 2 a 7 , verificou-se que as épocas de semeadura em estudo tiveram comportamento diferente para os seguintes parâme tros avaliados: duração do ciclo, rendimento, altura de 
planta, indice de acamamento e peso de 1000 sementes; en tretanto, o mesmo não aconteceu para altura de inserção das 1as vagens.

Quanto à duração do ciclo, a literatura revela a existência de uma variação apresentada por diferentes épocas de semeadura (FEASTER, 1949; ABEL, 1961 ; CARTER, 1974 ; COSTA, 1975; CONSTABLE, 1977; GIMARAES et alii, 1978; MONTEIRO et alii, 1980; COSTA et alii, 1984; MARCOS FILHO et alii, 1984). No presente trabalho foi possivel diferenciar as épocas de semeadura conforme demonstrado no Apêndice 2. Verificou-se que a medida que retardou a época de semeadura, houve uma diminuição na duração do ciclo. Variações anuais no comportamento de épocas de semeadura, foram atribuídas às alterações da temperatura que ocorreram de ano para ano (GARDNER e ALLARD, r930; HARTWIG, 1973). Quanto à produção de semente de soja, a literatura se refere ao comportamento diferencial observado entre épocas de semeadura (FEASTER, 1949; DIMMOCK e WARREN, 1953; HARTWIG, 1954; SMITH, 1954; TORRIE e BRIGGS, 1955; COSTA, 1975 ; CONSTABLE, 1977; ROLIM, 1977; GUIMARAES et alii, 1978; MONTEIRO et alix, 1980; ABEL, 1981; NAKAGAWA, 1981; COSTA et alii, 1984; MARCOS FILHO et alii, 1984). No presente trabalho foi possivel diferenciàr as 4 ëpocas đe semeadura, conforme demonstrado no Apêndice 3. As 
épocas de semeadura que mais se destacaram foram a segunda e.terceira épocas. Verificou-se variação no rendi mento entre épocas de semeadura para os cultivares Para ná, Bossier, IAC-8, IAC-6 e Paranagoiana.

Quanto ao indice de acamamento, diversos autores relataram o comportamento diferente, entre épocas de semeadura (SILVA et alii; 1970; SANTOS, 1975; ROLIM, 1977; MONTEIRO et alii, 1980; COSTA et alii, 1984). Atravês dos resultados obtidos verificou-se diferenças entre épocas de semeadura para este parâmetro. Os menores indices de acamamento foram obtidos nas segunda e terceira épocas, de acordo com Apêndice 4.

Quanto à altura de planta, a literatura revela comportamento diferente entre época de semeadura (SILVA et alii, 1970; SANTOS, 1975; ROLIM, 1977; MONTEIRO et alii, 1980; COSTA et alii, 1984). Segundo SANTOS (1975), o porte apresentado por cultivares de so ja, para caracterizar uma variedade, deve ser feita referência à época e ao local de semeadura. Através dos dados obtidos no presente trabalho, apresentados no Apêndice 5, pode-se verificar que as épocas de semeadura tiveram comportamento diferentes. Houve um aumento na altura das plantas com o retardamento da época de semea dura.

Quanto à inserção das 1 ạs vagens, a lite 
ratura revela a existência de uma variação entre diferentes épocas de semeadura (HARTWIG, 1973; SANTOS, 1975; ROLIM, 1977; MONTEIRO et alii, 1980; COSTA et alii, 1984). De acordo com os resultados obtidos (Apêndice 6), não houve diferença na média entre as quatro épocas de semeadura avaliadas.

Quanto ao neso de 1000 sementes, a literatura revela a existência de uma variação entre diferentes épocas de semeadura, vindo a mostrar que a varia ção climática anual é um fator importante em determinar o peso de sementes (FEASTER, 1949; SMITH, 1954; LEFFEL, 1965; NICHOLSON e SINCLAIR, 1973; SANTOS, 1975; ROLIM, 1977; NAKAGAWA, 1981; COSTA et alii, 1984; MARCOS FILHO et alii, 1984). No presente trabalho foi possível diferenciar as épocas de semeadura consideradas, confor me Apêndice 7 .

$\bar{A}$ medida que retardou a época de semeadu ra, houve uma diminuição no peso das sementes.

Através dos resultados obtidos nos testes de sanidade, e considerando-se também as caracterís ticas agronômicas apresentadas nos Apêndices 2 a 7 , pode-se sugerir que semeaduras em novembro sejam as mais adequadas para a produção de sementes no Estado de Goiás. O período de semeadura sugerido (em torno de mea dos de novembro) está de acordo com a recomendação de 
CostA (1977). Entretanto, estudos mais detalhados devem ser realizados durante vários anos agrícolas, procurando-se correlacionar os fatores climáticos (Apêndice 1) com o desempenho dos cultivares mais recomendados para a região, semeados em diversas épocas, a fim de se acumular uma sêrie de dados que permitam conclusões mais amplas e seguras.

Deve-se considerar que a época de semeadura está bastante relacionada com a época de colheita, período em que as condições meteorológicas afetam baștante a qualidade das sementes. Quanto a este fator, de ve-se também considerar a precocidade dos cultivares es tudados (Apêndice 2), jā que cultivares semeados na me ma época devem ser colhidos em épocas diferentes, em função da duração do seu ciclo. Deve-se também conside rar que, entre os diversos aspectos referentes ao desem penho dos cultivares em campo, de produção de sementes, a ocorrência e severidade de doenças e pragas podem ser afetados pela época de semeadura, já que são fatores bas. tante influenciados pelas condições climáticas. 
Os resultados obtidos nas condições em que se desenvolveu o presente estudo permitiram concluir que :

6.1. Dos cultivares avaliados, Doko, Tropical e Cris talina foram os que apresentaram, de maneira ge ral, melhor qualidade de sementes, particular mente quanto à sanidade.

6.2. Das época de semeadura consideradas, 19,/ novembro foi a que proporcionou, de maneira geral, melhor qualidade de sementes de soja, particularmente quanto à sanidade. 
6.3. Dentre os testes de sanidade estudados, o método do papel de filtro sem congelamento foi o mais adequado para a deteç̧ão de microrganismos asso ciados a sementes de soja, por proporcionar maior facilidade de detecção e identificação, particu larmente de organismos patogênicos à soja.

6.4. Dos cultivares avaliados, Cristalina, Tropical, UFV-1, Paranagoiana, Bossier e Doko foram os que mais se destacaram quanto aos caracteres agronômicos. Das época de semeadura consideradas a terceira época foi a que mais se destacou. 
105.

7. LITERATURA CITADA

ABEL, G.H., 1961. Response of soybeans to dates of planting in the Imperial Valley of California. Agr. Jour. Madison, 53(2): 95-98.

AGRIOS, G.N., 1972. Plant Pathology. 3ạ ed. New York, London, Academic Press. 629 p.

ALLARD, R.W., 1975. Princípios de la Mejora Genética de las Plantas. 2 a ed. Barcelona, Ed. Omega S.A. 498 p.

ALMEIDA, A.M.R. e L.C. MIRANDA, 1978. Aspectos da ocor rência do mosaico comum da soja em sementes e sua transmissibilidade. Fitopatologia Brasileira, $\underline{3}(1)$ :

74 [Resumo].

ANSELME, C.L.; F. JAILLOUX e R. CHAMPION, 1966. Methodes d'analyse sanitaria das semences de lin. Proc. Int. Seed Test. Ass. 31(2): 157-167. 
ANTEPARA, E.H.; E.A. ROSSETO e C.T. WETZEL, 1979. Micro flora em sementes de soja com diferentes tipos de da nos. I Congresso Brasileiro de Sementes, Curitiba, PR. ABRATES, p. 90 [Resumo].

ARX, J.A. von, 1957. Die Arten der Gattung Colletotrichum Cda. Phytopath. Z., 29: 413-469.

ATHOW, L.K., 1970. Diseases caused by viruses. In: I Simpósio Brasileiro de Soja. Ministério de Agricultura/Secretaria da Agricultura, SP, Campinas-SP, p. $38-40$.

ATHOW, K.L. e F.A. LAVIOLETTE, 1973. Pod protection effects on soybean seed germination and infection with Diaporthe phaseolorum var. sojae and other microrganisms. Phytopathology, 63: 1021-1023.

BARNETT, H. L. e B.B. HUNTER, 1972. Illustrated Genera of Imperfect Fungi. 3 a ed. Minneapolis, Burgess Publishing Company, $241 \mathrm{p}$.

BARNI, N.A. e J.C. GONÇALVES, 1977. Cultivo da soja em terras de arroz. IPAGRO inf., 18: 15-18.

BARROS, S.T.; M. MENEZES; M.J. FERNANDES e N.P. LIRA, 1983. Condições sanitärias das sementes de 34 culti vares de feijão massacar, Vigna unguiculata (L.) Walp. no Estado de Pernambuco. XVI Congresso de Fitopatologia Brasileira. Belém/PA. p. 105. [Resumo]. 
BARROS, B.O.; M.H. SUGIMORI; P.R. MARIOTTO; J.O.M. MENTEN; C.A. MORAES e A. SAVI FILHO, 1984. Efeito do tràtamento químico de sementes de mamona avaliado por diferentes métodos de patologia de sementes. VII Congresso Paulista de Fitopatologia. Botucatu/SP, p. 9. [Res umo].

BATRA, L.R., 1973. Nematosporaceae (Hemiascomycetidae); taxonomy, pathogenicity, distribution and vector relation. Agric. Res. Service (USDA). Tech. Bull. n? $1469,71 \mathrm{p}$.

BERNAUX, P.,.1976. Le Cercospora kikuchii Mats. e Tom. De soja en France. Ann. Phytopathol. 8(1): 83-86.

BOLKAN, H.A.; A.R. SILVA e F.P. CUPERTINO, 1976. Fungi associated with soybean and bean seeds and their control in Brazil Central. Plant. Dis. Reptr., 60: 545-548 .

BOOTH, C., 1971. The genus Fusarium. Commonwealth Myco logical Institute Kew, Surrey, England. 237 p.

BRANDAO, S.S., 1961. Contribuição ao estudo de varieda des de soja (Glycine max (L.) Merrill). Experientiae, Viçosa, $\underline{I}(4): 119-199$.

CARTER, O.G., 1974. Detailed yield analysis of the effect of different planting dates on seven soybean varieties. Iowa States Journal of Research, 48: 291310 . 
108.

CARDOSO, E.J.B.N., 1980. Doenças da soja. In: Manual de Fitopatologia. Doenças das Plantas Cultivadas,

Vol. I I, p. 480-481.

CASTOR, L.L. e R.A. FREDERIKSEN, 1978. Fusarium and Curvularia grain molds in Texas. In: Sorghum Diseases: A World Review. p. 33-102. Proceedings of the International Workshop at ICRISAT, Hyderabad, India. $469 \mathrm{p}$.

CHAMBERLAIN, D.W. e B. KOEHER, 1951. Soybean diseases in Illinois. University of Illinois. Circular no $676,31 \mathrm{p}$.

CHAMBERLAIN, D.W. e L.E. GRAY, 1974. Germination, seed treatment and microrganisms in soybean produced in Illinois. Plant Dis. Report. 58: 50-54.

CHAGAS, D. e O.D. DHINGRA, 1979. Effect of timing of weed control on the incidence of seedborne fungi in dry bean seeds. Fitopatologia Brasileira, 4(3): 423-426 .

CHEN, M.D.; S.D. LYDA e R.S. HALLIWELL, 1979. Imperfec tion of soybeans with conidia of Cercospora kikuchii. Mycologia, 71: 1158-1165.

COMISSÃO ESTADUAL DE FERTILIDADE DO SOLO, 1980. Recomendações de fertilizantes para Goiás, 4ạ aproximação. Goiânia - Goiás. 54 p.

COMPENDIUM OF SOYBEAN DISEASES, 1975. St. Paul, Minnesota, the American Phytopathology Society. 69 p. 
CONOVER, R.A., 1948. Studies of two viruses causing mosaic diseases in soybean. Phytopathology, 38: 724-735 .

CONSTABLE, G.A., 1977. Effect of planting date on soybeans in the Nonoi Valley, New South Wales. Aust.J. Exp. Agric. Anim. Husb., 17: 148-155.

COSTA, A.S., 1972. Investigações sobre moléstias do fe joeiro no Brasil. In: Anais do I Simpósio Brasileiro do Feijão. M.A.S.E.S.P., Un. Fed. Viçosa, Imprensa Universitária, Viçosa/MG, Vol. II, p. 303-384.

COSTA, A.S.; S. MIYASAKA; R.A.S. KIIHL e J.D. DEMATTE, 1970. Doenças de virus da soja em São Paulo. I Simpósio Brasileiro de Soja. Campinas - SP, p. 34.

COSTA, A.V,, 1975. Estudo sobre época de plantio da so ja. Bol. Téc. EMGOPA, Goiânia - Goiās, 1: 23-27.

COSTA, A.V., 1977. Contribuição para a melhoria da qua lidade da semente de soja produzida no Estado de Goiās. Empresa Goiania de Pesquisa Agropecuária - EMGOPA. Indicação de Pesquisa, no 4, 4 p.

COSTA, A.S. e V.C. LIMA NETO, 1974. Baixa transmissão do virus do mosaico comum da soja pela semente em São Paulo. VII Congresso da Sociedade Brasileira de Fitopatologia. p. 50 [Resumo]. 
COSTA, A.V.; P.M.F.O. MONTEIRO e R.B. ROLIM, 1984. Efei to da época de plantio na germinação de 16 cultivares de soja em Goiânia/GO. III Seminärio Nacional de Pesquisa de Soja. Campinas/SP. p. 119 [Resumo].

COSTA, N.P.; L.A.G. PEREIRA; J.B. FRANCA NETO; A.A. HEN NING e J. YAMASHITA, 1981. Avaliação da qualidadede semente de soja produzida nas safras de 1976/77 e 1978/79 no Estado do Paraná. Comunicado Técnico nọ 9 - Centro Nacional de Pesquisa de Soja, iLondrina/PR. $10 \mathrm{p}$.

CRITTENDEN, H.W. ; H.E. BLOSS e F.A. YELEN, 1967. Pod and stem blight of the soybean in Delaware. Delaware Agric. Exp. Stn. Circ. 4 .

DAUGHERTY, D.M., 1967. Pentatomidae as vectors of yeastspot disease of soybeans. J. Econ. Entomology, 60: $147-152$.

DEBROT, E.A.C. e C.E.B. ROJAS, 1967. Identificaccion del virus de mosaico de la soya en Venezuela. Agronomia Tropical, 17: 75-86.

DIAZ-POLANCO, C., 1966. Cercospora kikuchii en soya, nuevo patógeno en Venezuela. Agronomia Tropical, 16 (3): 213-221.

DIMMOCK, F. e F.S. WARREN, 1953. The influence of time of planting on the yield and composition of soybean seed. Can. J. Agric. Sci., 33: 550-558. 
DHINGRA, O.D., 1978. Internall seedborne Fusarium semitectum and Phomopsis sp. affecting dry and snap bean seed quality. Plant Dis. Report, 62: 509-512.

DHINGRA, O.D.; A. GARCIA e T. SEDIYAMA, 1979. Effect of planting time on seed infection by Phomopsis sojae in ten soybean cultivars. Fitopatologia Brasileira, 4 (3): $435-440$.

DHINGRA, O.D.; C. SEDIYAMA; I.M. CARRADO e M.S. REIS, 1978. Behavior of four soybean cultivars to seed-in fecting fungi in delayed harves. Fitopatologia Brasileira, $3(3)$ : 277-282.

DHINGRA, O.D. e J.B. SINCLAİ, 1978. Biology and Pathology of Macrophomina phaseolina. Universidade Federal de Viçosa. Viçosa/MG, $166 \mathrm{p}$.

DHINGRA, O.D. e J.F. SILVA, 1978. Effect of weed control on the internally seedborne fungi in soybean seeds. Plant Dis. Report, 62 (66): 513-516.

DHINGRA, O.D. e J.J. MUCHOVEJ, 1979. Pod rot, seed rot and rot of snap bean and driy bean caused by Fusarium semitectum. Plant Dis. Report, 63: 84-87.

DHINGRA, O.D.; T. SEDIYAMA e C. SEDIYAMA, 1979. Effect of planting and harvest time on seed infection of soy bean by Phomopsis sojae and Fusarium semitectum. Fitopatologia Brasileira, 4(3): 467-472. 
DHINGRA, O.D.; T. SEDIYAMA; M.S. REIS e J.G. SILVA, 1979. Variability in soybean cultivars to seed infection by Phomopsis sojae and other fungi. Fitopatologia. Brasileira, 4: 1-4.

DUNLEAVY, J.M., 1973. Virus Diseases. In: B.E. Caldwell et alii (ed.). Soybeans: Improvement, Produc-. tions and Uses. p. 505-526. An. Soc. Agron. Inc. 16: 681 .

DUNLEAVY, J.M., 1976. Pathological factors affecting seed germination. In: L.D. Hill (ed.). World Soy-. bean Research. Interstate Printers and Publishers. Inc., Danville, Illinois. p. 462-469.

DUNLEAVY, J.M.; D.W. CHAMBERLAIN e J.P. ROSS, 1966. Soy bean diseases. U.S.D.A. Agric. Handbook. 302: 38.

DUNLEAVY, J.M.; S.S. QUINIONES e C.J. KRASS, 1970. Poor seed quality and rugosity of leaves of virus - infec: ted hood soybeans. Phytopathology, 60: 883-886.

ELLIS, M.B., 1971. Dematiaceus Hyphomycetes. Commonwealth Mycological Institute Kew, Surrey, England. $608 \mathrm{p}$.

ELLIS, M.A., 1976. More Dematiaceus Hyphomycetes. Commonwealth Mycological Institute Kew, Surrey, England. $507 \mathrm{p}$. 
ELLIS, M.A.; C.C. MACHADO; C. PRASARTSEE e J.B. SINCLAIR, 1972. Ocurrence of Diaporthe phaseolorum var. sojae (Phomopsis sp.) in various soybean seedlots. Plant Dis. Report., 58: 1-8.

ELLIS, M.A.; C.C. MACHADO; C. PRASARTSEE e J.B. SINCLAIR;. 1974. Ocurrence of Diaporthe phaseolorum var.sojae (Phomopsis sp.) in various soybean seedlots. Plant Dis. Report., 58: 173-176.

ELLIS, M.A.; E.G.E.GALVEZ e J.B. SINCLAIR, 1976. Efecto de tres fungicidas en la germinacion de semilla infecta da de frijol (Phaseolus vulgaris). Turrialba, 26: 399-402.

ELLIS, M.A.; F.D. TENNE e J.B. SINCLAIR, 1977. Effect of antibiotics and high temperatura storage on decay of soybean seeds by Bacillus subtilis. Seed Sci. \& Technol., 5: 753-761.

ELLIS, M.A.; E.G.E. GALVEZ e J.B. SINCLAIR, 1977. Efecto del tratamiento de semillas de frijol (Phaseolus vulgaris) de buena y mala calidad sobre la germinacion en condiciones de campo. Turrialba, 27: 37-39.

ELlis, M.A.; E.H. PASChAl II; P.E. POWELl e F.D. TENNE, 1979. Internally seedborne fungi of soya bean in Puerto Rico and their effect on seed germination and field emergence. Trop. Agric. Trinidade, 56 (2): 171174 .

FEASTER, C.V., 1949. Influence of planting date on yield and other characteristics of soybeans in Southeast Missouri. Agr. Jour., Madison, 41 (2): 57-62. 
FEHR, W.R. e C.E. CAVINESS, 1977. Stages of soybean de velopment. Ames, Iowa State University of Science and Technology, $11 \mathrm{p}$.

FERREIRA, L.P., 1973. Principais doenças da soja. Atualidades Agronômicas, 4: 54-61.

FERREIRA, R.G. e M. MENEzes, 1983. População füngica em sementes de 31 cultivares de feijão Phaseolus vulgaris L. no Estado de Pernambuco. XVI Congresso Brasileiro de Fitopatologia. Belém/PA, p. 106 [Resumo].

FOOR, S.R.; F.D. TENNE e J.B. SINCLAIR, 1976. Occurence of seeborne microrganisms and germination in culture for determining seed health in soybean. Plant Dis. Report., 60: 970-973.

FRANCA NETO, J.B.; A.A. HENNING e P.N. COSTA, 1983. Efeito de diferentes níveis de mancha púrpura sobre a qualidade de sementes e o rendimento de soja (Glycine $\max$ (L.) Merril1). III Congresso Brasileiro de Sementes, Campinas/SP - ABRATES, p. 75 [Resumo].

FRENHANI, A.A., 1969. Antracnose em sementes de soja. 0 Biológico, 35: 291 .

FULCO, W.S., 1977. A semente de soja e sua importância na transmissão de moléstias. IPAGRO - INFORMATIVO. Porto Alegre/RS, $56 \mathrm{p}$.

FULCO, W.S.; M.H.G. SOARES e M.R.O. CAMARGO, 1977. Estudo da transmissibilidade de moléstias pela semente de soja (Glycine max (L.) Merrill). Agron. Sulriograndense, Porto Alegre/RS, 13(2): 309-318. 
FULCO, W.S.; P.S. LEHMAN e A.T. CRESPO, 1975. Transmissão de moléstias através das sementes de soja (Glycine $\max$ (L.) Merril1). In: Reunião Conjunta de Pesquisa da Soja - RS/SC, Porto Alegre/RS, $\underline{3}(7): 40$.

FULCO, W.S.; P.S. LEHMAN e A.T. CRESPO, 1979. Epoca de colheita da soja como fator de qualidade de sementes. Fitopatologia Brasileira, 4: 25-40.

GALLI, F.; K. NINOMYIA e F.D. CONCEICCAO, 1963. Nematos pora coryli Peglion, agente causal de mancha em feijão comum, Phaseolus vulgaris L. Olericultura, 3: $1-4$.

GARNER, W.W. e H.A. ALLARD, 1930. Photoperiodic response of soybeans in relation to temperature and other environmental factors. J.Agric. Res., 41: 719-735.

GARDNER, M.W. e J.B. KENDRICK, 1921. Soybean mosaic. Journ. Agric. Res., 22: 111-114.

GLUECK, J.A. e L.W. ROONEY, 1976. Physical and Chemical characterization of sorghum lines with resistance to grain deterioration. Cereal Foods World, 21: 436-437.

GOMES, J.C., 1975. Fungos associados à mancha púrpura da soja e variações de germinação. In: Reunião conjunta de Pesquisa da'soja - RS/SC. Porto Alegre/RS, 3(7): 10.

GOMES, F. P., 1970. Curso de Estatistica Experimental,... 4 ạ ed., São Paulo, Nobel, 430 p. 
GOMES, J.L.L.; T. SEDIYAMA; C.S. SEDIYAMA; P.R.A. ARAUJO; A.K. NOMURA; M.G. PEREIRA e M.G. RIBEIRO, 1982. Efeito de cinco épocas de plantio de vinte e um cultivares de soja, sobre a incidência de patógenos nas sementes. XV Congresso Brasileiro de Fitopatologia, São Paulo/SP, p. 13 [Resumo].

GOMES, J.L.L.;T. SEDIYAMA; C.S. SEDI YAMA; P.R.A. ARAOJO; A.K. NOMURA; M.G. PEREIRA; M.G. RIBEIRO e A.F. BOLDT, 1983. Efeito em quatro épocas de plantio de trinta e sete genótipos de soja, sobre a incidencia de pató genos nas sementes. XVI Congresso Brasileiro de Fitopatologia, Belém/PA, p. 104. [Resumo].

GOMES, J.L.L.; T. SEDIYAMA; H.J. DUTRA; C.S. SEDIYAMA; G.M. PEREIRA e B.A. OLIVEIRA, 1983. Avaliação da in cidência de patógenos nas sementes de genótipos de soja, em Capinópolis/MG. XVI Congresso Brasileirode Fitopatologia, Belém/PA, p. 103. [Resumo].

GRAY, E.; G.D. LACEFIELD e J.A. LOWE, 1971. Head mold on grain sorghum. Plant Dis. Report., 55: 337-339.

GREEN, D.E.; E.L. PINNEL; L.E. CARAVAH e L.F. WILLIAMS, 1965. Effect of planting date and maturity date on soybean seed quality. Agron. Jour. Madison, $\underline{57(2):}$ $165-168$.

GUIMARAES, J.A.P.; N.E. ARANTES e G.P. RIOS, 1978. Estudo do efeito de seis épocas de plantio em duas cul tivares de soja e em três espaçamentor, no município de Uberaba, MG. Projeto Soja, Relatório 75/76, Belo Horizonte, 1 : $86-89$. 
HAN, H. e D. MURAYAMA, 1970. Studies on soybean mosaic virus. I. Separation of virus strains by differential host. Journ. Fac. Agr. Hokkaido Unv. Sapporo, 56: $303-310$.

HARTWIG, E.E., 19.54. Factors effecting time of planting soybeans in the Southern States. U.S. Dep. Agric., Circ. 943.

HARTWIG, E.E., 1973. Varietal development in soybeans. In: CALDWELL, B.E. (ed.). Soybeans: Improvement, Production and Uses. Madison American Society of Agronomy. p. 187-210.

HEINZE, K. e E. KOHLER, 1940. Die masaikkrankheit der sojabohne und ihre ubertragung durah insekten. Phytopath. 2., 13: 207-242.

HEI NRI CHS, E.A. ; P.S. LEHMAN e I.C. CORSO, 1976. Nematospora coryli, yeast-spot disease of soybeans in Brazil. Plant Dis. Report., 60 (6): 508-509.

HENNING, A.A. e J.B. FRANÇA NETO, 1980. Problemas na avaliação da germinação de sementes de soja com a1ta incidência de Phomopsis sp. Revista Brasileira. de Sementes, 2: 9-22.

HEPPERLY, P.R. e J.B. SINCLAIR, 1980. Associations of plant symptoms and pod position with Phomopsis sojae seed infection and damage in soybean. Crop Science, 20: $379-381$. 
HEPPERLY, P.R. e J.B. SINCLAIR, 1981. Relationships among Cercospora kikuchii, other seed mycoflora, and germination of soybean in Puerto Rico and Illinois. Plant Dis. Report., 65: 130-132.

HEWETT, P.D., 1979. Diseases testing in a seed Improvement program. In: Seed Pathology Problems and Pro-. gress. Londrina, PR, Brazil. p. 72-88.

HINO, T. e H. TOKESHI, 1978. Some pathogens of Cercosporiosis collected in Brazil and Japan. Tropical Agricultural Research Center, Ministry Agricultura, Forestry and Fisheries. (Technical Bulletin Tarc. 11) $57 \mathrm{p}$.

HOMECHIN, M.; J.T. YORINORI e J.R. MENEZES, 1977. Patógenos da soja transmitidos pela semente no Estado do Paraná. Fitopatologià Brasileira, 2: 79-80.

HORN, N.L.; L.D. NEWSON; R.G. CARVER e R.L. JENSEN,1971. Effects of virus diseases on soybean in Louisiana. Louisiana Agric., 13: 12-13.

IIZUKA, N., 1973. Seed transmission of viruses in soybean. Tohoku Nat. Agr. Exp. Sta. Bul1. 46: 131-141.

ISSA, E. e H.A.A. MASCARENHAS, 1971. Resistência varie tal da soja (Soja max L.) à mancha pürpura (Cercospo rina kikuchii Mats. e Tomo.) e à pústula bacteriana (Xanthomonas phaseoli var. sojense (Hedges) Starr. Buekholder) no período de 1967 a 1970. Fitopatologia Brasileira, 4: 83-86. 
ITO, M.F.; J. SOAVE; P.O. PARADELA e M.A.C. MIRANDA, 1981. Fungos associados a sementes de soja em vários locais do Estado de São Paulo. IV Congresso. Paulista de Fitopatologia. Campinas/SP, p. 34 [Resumo].

JOHNSON, H.W., 1922. The relation of air temperature to the mosaic diseases of potatoe and other plants. Phytopathology, 12: 438-440.

JOHNSON, H.W.; D.W. CHAMBERLAIN e S.G. LEHMAN, 1954. Diseases of soybeans and methods of control. USDA, Circular 931: 40.

JONES, J.P., 1968. Survival of Cercospora kikuchii on soybean stems in the field. Plant Dis. Report. $\underline{52}$ (12): 931-934.

KENDRICK, J.B. e M.W. GARDNER, 1924. Soybean mosaic: seed transmission and effect on yield. Jour. Agric. Res., 27: 91-98.

KHARE, M.N.; S.B. MATHUR e P. NEERGAARD, 1977. A seedling symptom test for detection of Septoria nodorum in wheat seed. Seed Sci. \& Thechnol., 5: 613-617.

KILPATRICK, R.A., 1951. Longevity of Cercospora kikuchii on soybeans stems. Phytopathology, 46: 58 [Abs tract].

KILPATRICK, R.A., 1953. Fungi associated with soybean seeds and pods, prior to harvest, at Stoneville, Mississipi, in 1952. Phytopathology, 43: 292. [Abstract]. 
KILPATRICK, R.A., 1957. Fungi associated with the flowers, pods and seeds of soybeans. Phytopathology, 47 (3): $131-135$.

KILPATRICK, R.A. e E.E. HARTWIG, 1955. Effect of planting date on incidence of fungus infection of ogden soybean seeds grown at walnut hill, Flórida. Plant. Dis. Report., 39: 175-176.

KIMATI, H. e K. NINOMYIA, 1964. Algumas plantas hospedeiras de Nematospora coryli Peglion. Revista de. Olericultura, 4: 107-109.

KMETZ, K.T.; C.W. ELLETT e A.F. SCHMITTHENNER, 1974. I SO lation of seedborne Diaporthe phaseolorum and Phomop. sis sp. from inature soybean plants. Plant Dis. Report., 58: 878-892.

KMETZ, K.T.; A.F. SCHMITTHENNER e C.W. ELLET, 1978. Soybean seed decay: Prevalence of infection and symptom expression caused by Phomopsis sp., Diaporthe phaseoZorum var. sojae, and $D$. phaseolorum var. caulivora. Phytopathology, 68: 836-840.

KOSHIMIZU, Y. e N. IIZUKA, 1963. Studies on soybean ví rus diseases in Japan. Bull. Tohoku Nat. Agric. Exp., 27: $1-103$.

KRUG, H.P., 1937. A podridão interna dos capulhos do al godoeiro no Estado de São Paulo. Inst. Agro. Campinas, Bo1. Tec. no 23, $19 \mathrm{p}$. 
KULIK, M.M., 1973. Detection of seed-borne microrganisms: other test. Seed Science and Technology, 1 (1): $255-280$.

KULIK, M.M. e J.P. SCHOEN, 1981. Effect of seedborne Diaporthe phaseolorum var. sojae on germination, emer gence, and vigor of soybean seedlings. Phytopathology, 71: $544-547$.

KULSHRESTHA, O.D.; S.B. MATHUR e P. NEERGAARD, 1976. Identification of seed-borne species of Colzetotrichum. Friesia, 11: 116-125.

LAMBAT, A.K.; S.P. RAYCHAUDHURI; V.C. LELE e R.P. NATH, 1969. Fungi intercepted on imported soybean seed. Indian Phytopathology, 22: 327-330.

LAM SANCHEZ, A. e L. YUYAMA, 1979. Epoca de plantio na cultura da soja (Glycine max (L.) Merril1), cultivares Santa Rosa e Viçoja em Jaboticabal, SP. Científica, 7: 225-234.

LASCA, C.C., 1978. Estudos sobre a flora füngica de sementes de feijão (Phaseolus vulgaris L.). O Bio1ógico, 44: 125-134.

LASCA, C.C.; B.C. BARROS e P.J. VALLARINI, 1983. Levantamento de fungos de sementes de trigo produzidos no Estado de São Paulo e comparação de incidência de manchas foliares com infecção de sementes por HeZminthosporium sativum. VI Congresso Paulista de Fitopatologia, Araras/SP, p. 63 [Resumo]. 
LAVIOLETTE, F.A. e K.L. ATHOW, 1972. Cercospora kikuchii infection of soybean as affected stage of plant development. Phytopathology, 62: 771 .

LAWRENCE, J.A. e B.W. KENNEDY, 1974. Pojulation changes of Pseudomonas glycines on germinating soybean seeds. Phytopathology, 64: 1470-1471.

LEACH, C.M., 1971. A practical guide to the effects of visible and ultra violet light on fungi. Methods in Microbiology, 4: 609-664.

LEACH, C.M., 1979. Environmental conditions and incubation period in seed health testing. In: Seed Páthology Problems and Progress. Londrina, PR. Brazil, p. 106-207.

LEACH, C.M., 1979. Theoretical consideration of the epi demiology of seed-born plant pathogens. In: Seed Pathology Problems and Progress. Londrina, PR, Brazil, p. 227-233.

LEACH, J.G. e G. CLULO, 1943. Association between Nematospora phaseoli and the green stinkbug. Phytopathology, 33: 1209-1211.

LEFFEL, R.C., 1961. Planting date and varietal effects on agronomic and seed compositional characters in soybean. Bull. Med. Agric. Exp. Sta., 117: 1-69.

LEHMAN, S.G., 1943. Occurrence of yeast spot soybean in North Carolina. Plant Dis. Report., 27: 602. 
LEHMAN, S.G., 1952. Survival of the purple seed stain fungus in soybean seeds. Phytopathology, 42(5): 285 [Abstract].

LEHMAN, S.G. e A.F. WOLF, 1926. Soybean antracnose. Journal of Agricultural Research, 33: 381-390.

LEHMAN, P.S.; C.C. MACHADO e M.T. TARRAGO, 1976. Frequência e severidade de doenças de soja nos Estados do Rio Grande do Sul e Santa Catarina. Fitopatologia Brasileira, 1 (3): 183-193.

LIMA, E.F.; L.P. CARVALHO e J.M.F. CARVALHO, 1982. Comparação de métodos de análise sanitária e ocorrência de fungos em sementes de algodoeiro. Fitopatologia Brasileira, 7: 401-406.

LIMA NETO, V.C., 1979. Influência do mosaico comum da soja sobre a planta e a qualidade da semente de soja (Glycine $\max$ (L.) Merrill). Piracicaba, ESALQ/USP, 156 p. [Tese de Doutorado].

LIMONARD, T., 1967. Some remarks on the preparation of agar tests in seed health investigation. Proc.Int. Seed. Ass., 32 (3): 603-614.

LIMONARD, T., 1968. Ecological aspects of seed health testing. Proc. Int. Seed Test. Ass., 33(3): 343-513.

LIMONARD, T., 1976. A modified blotter test for seed health. Neth. J. P1. Path., 72: 319-321. 
LING, L., 1940. Seedling stem blight caused by Glomerezla grycines. Phytopathology, 30: 345-347.

LUCCA FILHO, A.0. e C.R. CASElA, 1983. Avaliação dos efeitos da mancha pürpura (Cercospora kikuchii) em soja. III Congresso Brasileiro de Sementes - ABRATES, Campinas/SP, p. 75 [Resumo].

LUTTRELL, E.S., 1947. Diaporthe phaseolorum var. sojae on crop plants. Phytopathology, 37: 445-465.

MARCOS FILHO, J. 1979. Qualidade fisiológica e maturação de sementes de soja [Glycine max (L.) Merrill]. Escola Superior de Agricultura "Luiz de Queiroz", Piracicaba-SP, $180 \mathrm{p}$. (Tese de Livre Docência).

MARCOS FILHO, J.; M.A.C. MIRANDA e Y.H. KOMATSU, 1984. Epoca de semeadura e qualidade fisiológica de sementes de soja. II Seminário Nacional de Pesquisa de Soja. Campinas/SP, p. 132 [Resumo].

MARTYN, E.B., 1942. Diseases of plants in Jamaica. Jamaica Dept. Sci. and Agri. Bull., 32:34.

MATHUR, S.K.; S.B. MATHUR e. P. NEERGAARD, 1975. Detection of seed-borne fungi in sorghum and location of Fusarium moliniforme in the seed. Seed Sci. \& Techno1., 3: 683-690.

MATSUMOTO, T. e R. TOMOYASU, 1922. Studies on purple speck of soybean seed. Annales Phytopathology Soc. Japan, 1: 114.

McGEE, D.C. e C.L. BRANDT, 1979. Effect of foliar application of Benomyl on infection of soybean seeds by Phomopsis in relation to time of inoculation. Plant Dis. Report., 63(8): 675-677. 
MENDES, B.M.J.; S.B. PAIVA; P. FRATIN e J.O.M. MENTEN, 1984. Avaliação de diferentes métodos de microrganismos em sementes de girassol (Helianthus annuus L.). VII Congresso Paulista de Fitopatologia, Botucatu,SP, p. 26 [Resumo].

MENESES, M.; J.L. BEZERRA e R.L.B. RAMOS, 1979. Microflora fúngica de sementes de quatro cultivares de a godão. Fitopatologia Brasileira, 4: 124 [Resumo].

MENEZES, J.R.; S.K. MOHAN; A. BIANCHINI e G.L. SOUZA, 1981. Qualidade sanitāria de sementes de feijão (Phaseolus vulgaris L.) no Estadó do Paranā. Fitopatologia Brasileira, 6: 497-508.

MENTEN, J.O.M., 1978. Sanidade, germinação e vigor de sementes de feijão (Phaseolus vulgaris L.). Summa Phytopathologica, 4: 105-119.

MENTEN, J.O.M.; A.G. MACHADO Jr.; M.H.D. MORAES; A. TULMAN NETO e A. ANDO, 1980. Efeito do genótipo na incidência de microrganismos em sementes de feijão(Pha seolus vulgaris). Summa Phytopathologica, 6 $(1,2)$ : 34-35 [Resumo].

MENTEN, J.O.M.; J.M. SALGADO; G.P. RIOS e P.C.T. CARVALHO, 1977. Aspectos de mancha nematospora em feijão (Phaseolus vulgaris L.) e soja (Glycine max (L.) Mer ril1). Fitopatologia Brasileira, 2: 91 [Resumos apre sentado no $X$ Congresso Soc. Bras. Fitop,, Recife/PE].

MENTEN, J.O.M.; W.J. GIACOMELLI; A. TULMAN NETO e A. AND0, 1979. Efeito da mancha de levedura na qualidade de sementes de feijão (Phaseolus vulgaris L.). Fitopatologia Brasileira, 4: 493-501. 
MONTEIRO, P.M.F.O.; A.C. BARROS; A.V. COSTA; E.A.MORAES; J. CORREIA NETO; R.B. ROLIM; W.P. CERQUEIRA; J. NUNES Jr.; E.F. QUEIROZ; G. SANTOS; I. BAYS; J.F. FARIAS; N. NEWMAIER; R.A.S. KIIHL e T. SEDIYAMA, 1980. Estudo de interação de práticas culturais em soja (Glycine $\max$ (L.) Merril1). Relatório Tec. Emp. Go. Pesq. Agrop. 1979, p. 190-193.

MORSE, W.J., 1950. History of soybean production. p. 359. In: K.S. Markley (ed.). Soybeans and soybean products. Vol. I. Interscience Publishers Inc., New York, $540 \mathrm{p}$.

MURAKISHI, H.H., 1951. Purple seed staim of soybeans. Phytopathology, 41: 305-318.

MUSKETT, A.E. e J.P. MALONE, 1941. The Ulster Method for the examination of flax seed for the presence of seed-borne parasites. Ann. App1. Biol., 28: 8-13.

NAKAGAWA, J., 1981. Efeitos da época de semeadura na produção e qualidade de sementes de soja (Glycine $\max$ (L.) Merril1). Botucatu/SP, 208 p. [Tese de Livre-Docência].

NANGJU, D., 1977. Effect of date of harvest on seed quality and viability of soybean. J.Agric. Sci., 89: 107-112.

NANGJU, D., 1979." Seed characters and germination in soybean. Expl. Agric., 18: 385-389. 
NASSER, L.C.B.; J.W. HENDRIX e W.J. KAISER, 1983. Levan tamento da microflora de sementes de várias cultivares de trigo (Triticum aestivum L.) produzidas no Es tado de Washington-EUA. XVI Congresso Brasileiro de Fitopatologia, Belém/PA, p. 94 [Resumo].

NATH, R.; P. NEERGAARD e S.B. MATHUR, 1970. Identifica tion of Fusarium species on seeds as they occur in Blotter test. Proc. Int. Test. Seed. Ass., 35(1): $121-144$.

NEERGAARD, P., 1973. Detection of seed-borne pathogens by culture tests. Seed Science and Technology, 1 (1): $217-254$.

NEERGAARD, P., 1977. Seed Pathology. London, MacMillan Press, 2 vol. 839 p.

NEERGAARD, P., 1979. Research in seed pathology - Basic and Technological Approaches. In: Seed Patholology Problems and Progress. Londrina/PR, Brazil, p. 196-207.

NICHOLSON, J.F. e J.B. SINCLAIR, 1973. Effect of planting date, storage conditions and seed borne fungi on soybean seed quality. Plant Dis. Report., 57: 770774 .

NICHOLSON, J.F.; O.D. DHINGRA e J.B. SINCLAIR, 1972. Internal seedborne nature of Diaporthe phaseolorum var. sojae and Phomopsis sp., and their effects on soybean seed quality. Phytopathology, 62: 1261-1263. 
NOBLE, M., 1965. Introduction to series 3 of the hadbook on seed health testing. Proc. Int. Seed Test. Ass., 30(4): 1045-1047.

NOBLE, M. e M.J. RICHARDSON, 1968. An Annotated List. of Seedborne Diseases. 2 a ed. Commonwealth Mycolofical Institute. Kew, Surrey, England. p. 53-56.

NOWELL, W., 1918. Internal diseases of cotton bolls in the west Indies, II. West Indian Bul1., 17: 1-26.

NUNES Jr., J. e J.O.M. MENTEN, 1984. Efeito da mancha púrpura na qualidade de sementes de soja (Glycine max (L.) Merril1) e na transmissão sistêmica de Cercospora kikuchii (Matsumoto e Tomoyasu) Gardner. III Seminārio Nacional de Pesquisa de Soja. Campinas/SP. p. 35 [Resumo].

PARADELA FILHO, O.; C.J. ROSSETO e A.S. POMPEU, 1968. Megalotomus parvus (Hem. Coriscidae), vetor de Nematospora coryli Peglion em feijão. Rev. Soc. Bras. Fitopatologia, 2: 206 .

PASCHAL II E.H. e M.A. ELLIS, 1978. Variation seed quality characteristics of Tropically grow soybeans. Crop. Sci., 18: $837-840$.

PASCHAL II, E.H. e M.A. ELLIS, 1979. Effect of genotype and harvest date on the incidence of seedborne fungi and field emergence of soybean. In: Seed Pathology Problems and Progress. Londrina/PR, Brazil. p. $179-189$. 
PEGLION, V., 1901. Ueber die Nematospora coryli, Pegl. Centralbatt fur Bakteriol. Abt. II, 7: 754-761.

PETERSON, J.L. e R.F. STRELECKI, 1965. The effect of variants of Diaporthe phaseolorum on soybean germination and growth in New Jersey. Plant Dis. Report. 49: $228-229$.

PHATAK, H.C., 1974. Seed-borne plant viruses: identification and diagnosis in seed health testing. Seed Science and Technology, 2(1):3-155.

POPINIGIS, F., 1975. Qualidade de sementes. Lavoura Arrozeira. Porto Alegre. Instituto Rio-Grandense do Arroz, 28 (282): 34-41.

PRESTON, D.A. e W.W. RAY, 1943. Yeast spot of soybeans and mungbeans caused by Nematospora coryli Peglion in Oklahoma. Plant Dis. Report. 27: 601-602.

QUINIONES, S.S., 1968. Soybean mosaic. Iowa State University. U.S.A., 74 p. [PhD Thesis].

QUINIONES, S.S. e S.M. DUNLEAVY, 1970. Identify of a soybean mosaic virus isolated from Glycine max variety Hood. Plant Dis. Report., 54: 301-305.

QUINIONES, S.S.; J.M. DUNLEAVY e J.W. FISHER, 1971. Performance of three soybean varieties inoculated with soybean mosaic virus and bean pod mottle virus. Crop Science, Ames, Iowa, 11: 662-664. 
RECOMENDAÇOES DA EMGOPA/CPAC, 1981. Recomendações de variedades e diversas práticas para cada tipo de so10 em 2 regiões do Estado de Goiảs e Distrito Federal. 5ạ Reunião de Pesq. de Soja das Regiões Centro-Oeste e Sudeste. Circ. Tec. 3 p.

REIS, E.M., 1975. A mancha pürpura da semente de soja. Lavoura Arrozeira, Porto Alegre, Instituto Rio-Grandense do Arroz, 28 (283): 52-56.

RICHARDSON, M.J., 1979. An Annotated List of Seed-Borne Diseases. Commonwealth Mycological Institute Kew, Surrey, England, $320 \mathrm{p}$.

RICHARDSON, M.J., 1981. An Annoted List of Seed-Borne Diseases Supplement 1 ( 3 a ed.). The Inst. Seed Test. Ass., Zurich. 78 p. ROBINSON, R.A., 1969. Diseàse resistance terminology. Rev. App1. Myco1., 48: 593-606.

RODRIGUES-MARCANO, A., e J.B. SINCLAIR, 1978. Fruting structures of colletotrichum dematium var. truncata and Phomopsis sojae formed in soybean seeds. Plant Dis. Report. 62(10): 873-876.

ROLIM, R. B., 1977. Comportamento de duas variedades e três linhagens de soja, em diferentes níveis de adubação fosfa tada em solos sob vegetação de Ituiutaba, MG e Goiânia, Go. Viçosa - MG, 73 p. (Tese de Mestrado).

ROSS, J.P., 1963. Interaction of the soybean mosaic and bean pod mottle viruses infecting soybean. Phytopathology, 53: 887 [Abstract].

ROSS, J.P., 1968. Effect of single and double infections of soybean mosaic and bean pod mottle viruses on soybean yield and seed characters. Plant Dis. Report., 52: 344-348. 
ROSS, J.P., 1969. Pathogenic variation among isolates of soybean mosaic virus. Phytopathology, 59: 829-832.

ROSS, J.P., 1970. Effect of temperature on mottling of soybean caused by soybean mosaic virus. Phytopathology, 60: 1798-1800.

ROSSEAU, J.0., 1977. Efeito do tratamento químico de sementes de soja (Glycine max (L.) Merrill), em relação a sua qualidade fisiológica. Pelotas/RS. 63 p. (Tese de Metrado).

SANTOS, O.S. dos, 1975. Comportamento de dez variedades de soja em diferentes ambientes do Estado do Rio Grande do Sul. Experimental, Viçosa-MG, 20: (4) 89-116.

SCHMITTHERNER, A.F. e D.T. GORDON, 1970. Effect of sequence and time of inoculation with soybean mosaic virus and tobacco ringspot virus on yield of soybean cultivars. Phytopathology, 60: 1312 .

SCHNEIDER, R.W.; O.D. DHINGRA;. J.F. NICHOLSON e J. B. SINCLAIR, 1974. Colletotrichum truncatum borne within the seed coat of soybean. Phytopathology, 64: 154-155.

SHOEN, J.F. e P. SCHLUB, 1980. Tests on Phomopsis - infected soybean seed under controlled storage conditions. Newsletter, 54: 65-67.

SHORT, B.J.; B.J. JACOBSEN; M.C. SHURTLEFF e J.B. SINCLAIR, 1981. Soybean seed quality and fungicide seed treatment. Report on Plant Diseases; $6 \mathrm{p}$.

SILVA, E.R.; S.S. BRANDAO; F.R. GOMES e J.D. GALVAO, 1970. Comportamento de variedades de soja (Glycine max (L.) Merrill), em algumas localidades de Minas Gerais. Experientiae, Viçosa, 10 (6): 123-183. 
SINCLAIR, J.B., 1978. Microorganisms affecting soybean seed quality. In: Eight Soybean Seed Research Conference, 1978. Illinois. U.S.A.

SINCLAIR, J.B., 1978. The seed-borne nature of some soybean pathogens, the effect of Phomopsis spp. and Bacizzus subtizis on germination, and their ocurrence in soybeans produced in Illinois. Seed Sci. \& Techno1., 6: 957-964.

SINCLAIR, J.B., 1979. Soybean seed pathology. p. 161 a 171. In: Seed Pathology Problems and Progress, Lon drina/PR, Brazil, $273 \mathrm{p}$.

SINCLAIR, J.B., 1980. International Soybean Program. no 23, Illinois, U.S.A., 79 p.

SINCLAIR, J.B. e M.C. SHURTLEFF, 1975. Co. ed. Compendium of Soybean Diseases. University of Illinois, Urbana-Champaign, I.L. Copy right. 32 p.

SINCLAIR, J.B. e O. DHINGRA, 1975. An Annotated Bibliography of Soybean Diseases, 1968-1974. College of Agriculture, University of Illinois at Urbana - Champaign. INTSOY. Series 7, $280 \mathrm{p}$.

SMITH, P.E., 1954. Planting dates for soybeans. Arkansas Farm. Research., 3 $(4): 4$.

SOAVE, J.; M.A. PIZZINATTO; J.A. USMERTI Jr.; O.B.A. CAMARGO; O.V. VILlELA e P.B. GALLO, 1983. Comportamento de cultivares de arroz irrigado a fungos manchadores de sementes. XVI Congresso Brasileiro de Fitopa-, tologia, Belém/PA, p. 94 [Resumo]. 
SONEGO, O.R. e H.A. BOLKAN, 1978. Fungos associados com sementes de dezesseis variedades de soja cultivadas no Brasil. XI Congresso da Sociedade Brasileira de. Fitopatologia, Viçosa/MG, 3(1): 106 [Resumo].

SPILKER, D.A.; A.F. SCHMITTHEMNER e C.W. ELLETT, 1981. Effects of humidity, temperature, fertility, and cul tivar on the reduction of soybean seed quality by Phomopsis sp. Phytopathology, 71: 1027-1029.

SUZUKI, K., 1921. Studies on the cause of purple seed of soybeans. Chosen. Assoc. Rep., 16: 24-28.

TAKATSU, A.; N.F. CLAUDIO e I.M.M. GOMES, 1976. Ocorrên cia de mancha de levedura do feijoeiro no Distrito Fe deral. Rev. Soc. Bras. Fitopatologia, 9: 22 .

TEDIA, M., 1976. Effect of storage conditions and environment during maturation on soybean seed quality and crop performance. Univ. Illinois, Urbana, $164 \mathrm{p}$. [PhD Thesis].

TEKRONY, D.M.; D.B. EGLI; R.E. STUTKEY e J. BALLES, 1983. Relationship between weather and soybean seed infection by Phomopsis sp. Phytopathology, 73: 914-918.

TENNE, F.D.; C. PRASARTSEE; C.C. MACHADO e J.B. SINCLAIR, 1974. Variation in germination and seed borne pathogens among soybean seed lots from three regions in Illinois. Plant Dis. Report., 58: 411-413. 
TEMPE, J. de, 1961. Routine method for determining the health condition of seeds in seed testining station. Proc. Int. Seed Test. Ass., 26 (1): 27-60.

TEMPE, J. de, 1962. Comparison of methods for seed health testing. Proc. Int. Seed Test. Ass., 27(3): 819-828.

TEMPE, J. de, 1963. The blotter method for seed health testing. Proc. Int. Seed Test. Ass., 26 (1): 133-151.

TEMPE, J. de, 1964. Recent development in seed health testining. Proc. Int. Seed. Test. Ass., 29(3): 479486 .

TEMPE, J. de, 1979. Cereal seed pathology. In: Seed Pathology Problems and Progress. Londrina/PR, Brazil. p. 103-119.

TIFFANY, L.H., 1951. Delayed sporulation of Corzetotrichum on soybean. Phytopathology, 41: 975-985.

TORRIE, J.H. e G.M. BRIGGS, 1955. Effect of planting date on yield and other characteristics of soybean. Agr. Jour., Madison, 47 (5): 210-212.

TU, J.C. e R.E. FORD, 1969. Translocation of maize mosaic and soybean mosaic viruses from inoculated leaves. Phytopathology, 59: 1158-1163.

U.S. REGIONAL SOYBEAN LABORATORY, 1972. The uniform soybean tests. Southern States Urbana and Illinois, $121 \mathrm{p}$. 
VASCONCELOS, F.A.T., 1963. Contribuição para o estudo do mosaico da soja. Anais do Instituto Superior de Agricultura, S. Paulo/SP, 26: 181-221.

YORI NORI, J.T., 1982. Doenças de Soja. p. 301-364. In: Fundação Cargill. Soja no Brasil Central. Campinas/ SP, Fundação Cargil1. 444 p.

YORINORI, J.T.; J.B. SINCLAIR; Y.R. MEHTA E S.K. MOHAN (ed.), 1979. Seed Pathology Problems and Progress. Fundação IAPAR, Londrina/PR, Brazil. 274 p.

YORINORI, J.T. e J.B. SINCLAIR, 1983. Harvest and Assay Methods for Seedborne Fungi in soybeans and their pathogenicitity. Int. J. Tropical Plant Diseases, 1: 53-59.

WALDEN, V.R. e W.L. SEAMAN, 1962. Seedborne aspects of Diaporthe phaseolorum in soybean. Phytopathology,52: 756 [Abstract].

WALLEN, V.R. e T.F. CUDDY, 1960. Relation of seedborne Diaporthe phaseolorum to the germination of soybean. Proc. Assoc. off Seed Anal., 50: 137-140.

WARWICK, D.R.N., 1982. Catálogo de Patógenos de Plantas Cultivadas não Registradas no Brasil. EMBRAPA/ CENARGEM, $143 \mathrm{p}$.

WETZEL, M.M.; A.F. URBEN e C.R. SPEHAR, 1981. Efeito de época de plantio sobre a germinação e a incidência de patógenos de cinco cultivares de soja (Glyci ne $\max$ (L.) Merril1). II Seminārio Nacional de Pesquisa de Soja, Brasilia/DF, p. 94 [Resumo]. 
WETZEL, M.M.V.S.; A.F. URBEN e M.G.R. FAIAD, 1983. Sobrevivência de Phompsis sojae Lehman em sementes de soja armazenada. XVI Congresso Brasileiro de Fitopatologia, Belém/PA, p. 102 [Resumo].

WILCOX, J.R.; F.A. LAVIOLETTE e K.L. ATHOW, 1974 . Deterioration of soybean seed quality associated with delayed harvest. Plant Dis. Report., 58: 130-133.

WILCOX, J.R. e T.S. ABNEY, 1973. Effects of Cercospora kikuchii on soybeans. Phytopathology, 63: 796-797.

WINGARD, S.A., 1922. Yeast-spot of lima beans. Phytopathology, 12: 525-532. 
137.

8. A P E N D I C E 
APENDICE 1 - Dados meteorológicos da Estação Experimental de Goiânia, relativos ao período de ou tubro de 1981 a junho de 1982.

\begin{tabular}{lccc}
\hline MESES & $\begin{array}{c}\text { Temperatura } \\
\text { média }\left({ }^{C}\right)\end{array}$ & $\begin{array}{c}\text { Precipitação } \\
\text { Pluvial }\end{array}$ & $\left.\begin{array}{c}\text { Unidade } \\
\text { relativa( }\end{array}\right)$ \\
\hline Outubro & 23,20 & 309,70 & 77,00 \\
Novenbro & 22,80 & 190,70 & 82,00 \\
Dezenbro & 23,20 & 378,50 & 80,00 \\
Janeiro & 22,60 & 435,60 & 87,00 \\
Fevereiro & 23,20 & 93,00 & 80,00 \\
Março & 23,00 & 396,70 & $84 ; 00$ \\
Abrii & 21,60 & 215,00 & 74,00 \\
Maio & 19,80 & 119,10 & 72,00 \\
Junho & 20,40 & 000,00 & 71,00 \\
& & & \\
\hline
\end{tabular}


APENDICE 2 - Duração do ciclo (dias) de quatorze cultivares de soja em quatro épocas de semeadura, no Estado de Goiàs, ano agrícola 1981/82.

\begin{tabular}{|c|c|c|c|c|c|c|}
\hline \multirow{2}{*}{ CULTIVARES } & \multicolumn{4}{|c|}{ EPOCAS DE SEMEADURA $\stackrel{\text { af }}{-}$} & \multirow{2}{*}{\multicolumn{2}{|c|}{ MEDIA }} \\
\hline & 21/out. & 30/out. & 09/nov. & 19/nov. & & \\
\hline Paraná & 93 & 93 & 96 & 90 & $93 a$ & \\
\hline Bossier & 107 & 103 & 103 & 99 & 103 & \\
\hline Santa Rosa & 111 & 113 & 109 & 107 & 110 & c \\
\hline IAC-2 & 127 & 124 & 120 & 115 & 121 & $\mathrm{~d}$ \\
\hline IAC- 8 & 129 & 127 & 124 & 121 & 125 & e \\
\hline$U_{F V}-1$ & 129 & 129 & 126 & 122 & 126 & e \\
\hline Numbaira & 129 & 129 & 127 & 124 & 127 & e \\
\hline IAC-7 & 135 & 134 & 133 & 126 & 132 & $f$ \\
\hline Cristalina & 139 & 137 & 135 & 129 & 135 & $\mathrm{~g}$ \\
\hline IAC-6 & 137 & 139 & 134 & 132 & 135 & $\mathrm{~g}$ \\
\hline Doko & 140 & 140 & 137 & 133 & 137 & gh \\
\hline EMGOPA-301 & 145 & 144 & 136 & 132 & 139 & $\mathrm{~h}$ \\
\hline Tropical & 143 & 144 & 141 & 143 & 143 & i \\
\hline Paranagoiana & 147 & 152 & 147 & 144 & 147 & 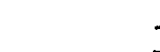 \\
\hline Média b/ & $129 c$ & $129 c$ & $126 \mathrm{~b}$ & $123 a$ & & \\
\hline
\end{tabular}

a/ Média de 3 repetições.

b/ Médias seguidas da mesma letra não diferiram significativamente entre si pelo teste Tukey ao nível de $5 \%$ de probabilidade. 
APENDICE 3 - Rendimento ( $\mathrm{kg} / \mathrm{ha}$ ) de quatorze cultivares de soja en quatro ëpocas de semeadura, no Estado de Goiäs, ano $\underline{\text { a }}$ grícola $1981 / 82$.

\begin{tabular}{|c|c|c|c|c|c|}
\hline \multirow{2}{*}{ CULTIVARES } & \multicolumn{4}{|c|}{ EPOCAS DE SEMEADURA } & \multirow{2}{*}{ MEDIA ${ }^{\mathrm{b} /}$} \\
\hline & 21/out. & 30/out. & 09/nov. & 19/nov. & \\
\hline Cristalina & 2.898 & 2.898. & 2.773 & 2.635 & $2.801 \mathrm{a}$ \\
\hline UFV-1 & 2.607 & 2.919 & 2.773 & 2.558 & $2.714 a$ \\
\hline Tropical & 2.614 & 2.886 & 2.517 & 2.489 & $2.626 a$ \\
\hline Numbaira & 2.219 & 2.794 & 2.804 & 2.503 & $2.580 \mathrm{a}$ \\
\hline Paranagoiana & 3.050 & 2.447 & 2.613 & 2.212 & $2.580 \mathrm{a}$ \\
\hline IAC-7 & 2.538 & 2.767 & 2.600 & 2.350 & $2.564 a$ \\
\hline Santa Rosa & 2.621 & 2.441 & 2.703 & 2.489 & $2.563 a$ \\
\hline IAC-6 & 2.274 & 2.800 & 2.517 & 2.281 & $2.468 \mathrm{ab}$ \\
\hline Doko & 2.585 & 2.558 & 2.383 & 2.274 & $2.450 \mathrm{ab}$ \\
\hline EMOOPA-301 & 2.406 & 2.517 & 2.481 & 2.142 & $2.386 a b$ \\
\hline IAC- 8 & 1.491 & 2.309 & 2.740 & 2.794 & $2.333 \mathrm{abc}$ \\
\hline IAC-2 & 2.164 & 1.871 & 2.045 & 2.212 & $2.073 \mathrm{bcd}$ \\
\hline Bossier & 1.601 & 1.789 & 2.295 & 1.920 & $1.901 \mathrm{~cd}$ \\
\hline Paraná & 1.463 & 1.366 & 2.340 & 1.907 & $1.769 \quad \mathrm{~d}$ \\
\hline Médiab/ & $2.324 \mathrm{~b}$ & $2.454 \mathrm{ab}$ & $2.542 a$ & $2.340 \mathrm{~b}$ & \\
\hline
\end{tabular}

a/ Média de 3 repetições.

b/ Médias seguidas da mesma letra não diferiram significativanente entre si pelo teste Tukey ao nível de 5\% de probabilidade. 
APENDI,CE 4 - Indices de acamamento ( 1 = quase todas plantas erectas; 5 = todas as plantas acamadas) de quatorze culti vares de soja em quatro épocas de semeadura, no Estado de Goiās, ano agrícola 1981/82.

\begin{tabular}{|c|c|c|c|c|c|}
\hline \multirow{2}{*}{ CULTIVARES } & \multicolumn{4}{|c|}{ EPOCAS DE SEMEADURA } & \multirow{2}{*}{ MEDIA $\mathrm{b} /$} \\
\hline & 21/out. & 30/out. & 09/nov. & 19/nov. & \\
\hline Paraná & 1,00 & 1,00 & 1,00 & 1,00 & $1,00 \mathrm{a}$ \\
\hline Bossier & 1,00 & 1,00 & 1,00 & 1,00 & $1,00 \mathrm{a}$ \\
\hline Santa Rosa & 1,00 & 1,00 & 1,00 & 1,00 & $1,00 \mathrm{a}$ \\
\hline UFV-1 & 1,00 & 1,00 & 1,00 & 1,00 & $1,00 \mathrm{a}$ \\
\hline EMGOPA-301 & 1,00 & 1,00 & 1,00 & 1,20 & $1,05 \mathrm{ab}$ \\
\hline Numbaira & 1,00 & 1,00 & 1,00 & 1,30 & $1,07 \mathrm{ab}$ \\
\hline IAC-7 & 1,00 & 1,00 & 1,00 & 1,30 & $1,07 \mathrm{ab}$ \\
\hline Cristalina & 1,20 & 1,00 & 1,00 & 1,50 & $1,17 \mathrm{ab}$ \\
\hline Paranagoiana & 1,20 & 1,00 & 1,30 & 1,40 & $1,22 \mathrm{ab}$ \\
\hline IAC-2 & 2,00 & 1,20 & 1,00 & 1,20 & $1,35 a b$ \\
\hline IAC- 6 & 1,20 & 1,30 & 1,30 & 1,70 & $1,37 \mathrm{ab}$ \\
\hline Doko & 1,50 & 1,30 & 1,50 & 1,70 & $1,50 \mathrm{bc}$ \\
\hline Tropical & 2,20 & 2,20 & 1,70 & 2,20 & $2,07 \mathrm{~cd}$ \\
\hline IAC- 8 & 4,30 & 1,00 & 1,90 & 1,80 & 2,25 \\
\hline Médiabl & $1,47 c$ & $1,14 \mathrm{a}$ & $1,18 \mathrm{ab}$ & $1,33 b c$ & \\
\hline
\end{tabular}

a/ Média de 3 repetições.

b/ Médias seguidas da mesma letra não diferiram significativamente entre si pelo teste Tukey ao nível de $5 \%$ de probabilidade. 
APENDICE 5 - Altura de plantas (om) de quatorze cultivares de soja em quatro épocas de semeadura, no Estado de Goiâs, ano agrícola 1981/82.

\begin{tabular}{|c|c|c|c|c|c|c|}
\hline \multirow{2}{*}{ CULTIVARES } & \multirow[b]{2}{*}{ 21/out. } & \multirow[b]{2}{*}{ 30/out. } & \multirow[b]{2}{*}{ 09/nov. } & \multirow[b]{2}{*}{ 19/nov. } & \multirow{2}{*}{\multicolumn{2}{|c|}{ MEDIA }} \\
\hline & & & & & & \\
\hline Paranagoiana & 96 & 94 & 107 & 115 & \multicolumn{2}{|l|}{$103 a$} \\
\hline Tropical & 97 & 95 & 107 & 110 & \multicolumn{2}{|l|}{$102 \mathrm{a}$} \\
\hline IAC-6 & 96 & 103 & 88 & 113 & \multicolumn{2}{|c|}{$100 \mathrm{ab}$} \\
\hline IAC-2 & 106 & 101 & 96 & 91 & \multicolumn{2}{|c|}{$98 a b$} \\
\hline Doko & 90 & 90 & 89 & 103 & \multicolumn{2}{|c|}{$93 \mathrm{bc}$} \\
\hline IAC-7 & 88 & 90 & 96 & 90 & \multicolumn{2}{|c|}{$91 \mathrm{bc}$} \\
\hline EMCOPA- 301 & 85 & 79 & 89 & 96 & 87 & \\
\hline IAC-8 & 95 & 72 & 84 & 91 & 85 & $\mathrm{~cd}$ \\
\hline Numbaira & 80 & 87 & 83 & 90 & 85 & $\mathrm{~cd}$ \\
\hline Cristalina & 77 & 76 & 73 & 88 & 78 & $\mathrm{~d}$ \\
\hline Santa Rosa & 53 & 56 & 66 & 67 & 60 & $\mathrm{e}$ \\
\hline Paraná & 53 & 42 & 63 & 62 & 55 & ef \\
\hline$U F-1$ & 41 & 49 & 54 & 61 & 51 & ef \\
\hline Bossier & 43 & 49 & 54 & 52 & 49 & $f$ \\
\hline Média & $78 b c$ & $77 c$ & $82 \mathrm{~b}$ & $88 a$ & & \\
\hline
\end{tabular}

a/ Média de 3 repetições.

b/ Médias seguidas da mesma letra não diferiram significativamente entre si pelo teste Tukey ao nível de 5\% de probabilidade. 
APENDICE 6 - Altura de inserção das 1 ạs vagens $(\mathrm{cm})$ de quatorze cul tivares de soja em quatro épocas de semeadura, no Es: tado de Goiās, ano aọrícola 1981/822.

\begin{tabular}{|c|c|c|c|c|c|}
\hline \multirow{2}{*}{ CULTIVARES } & \multicolumn{4}{|c|}{ EPOCAS DE SEMEADURA $\stackrel{\text { a/ }}{ }$} & \multirow{2}{*}{ MEDIA } \\
\hline & 21/out. & 30/out. & 09/nov. & 19/nov. & \\
\hline Tropical & 23,00 & 23,00 & 20,00 & 23,00 & $22,25 a$ \\
\hline Doko & 23,00 & 20,00 & 19,00 & 23,00 & $21,25 \mathrm{ab}$ \\
\hline IAC- 6 & 20,00 & 20,00 & 21,00 & 21,00 & $20,50 a b c$ \\
\hline Paranagoiana & 19,00 & 19,00 & 22,00 & 21,00 & $20,25 \mathrm{abcd}$ \\
\hline Numbaira & 20,00 & 20,00 & 17,00 & 15,00 & 18,00 bcde \\
\hline IAC-8 & 20,00 & 17,00 & 16,00 & 18,00 & 17,75 cde \\
\hline BMOOPA-301 & 15,00 & 16,00 & 18,00 & 21,00 & 17,50 cde \\
\hline IAC-7 & 16,00 & 18,00 & 17,00 & 13,00 & 16,00 cdef \\
\hline IAC-2 & 19,00 & 15,00 & 13,00 & 14,00 & 15,25 defg \\
\hline Cristalina & 14,00 & 17,00 & 12,00 & 15,00 & 14,50 \\
\hline UFV-1 & 12,00 & 11,00 & 11,00 & 12,00 & 11,50 \\
\hline Paranā & 12,00 & 9,00 & 11,00 & 12,00 & 11,00 \\
\hline Santa Rosa & 7,00 & 10,00 & 12,00 & 13,00 & 10,50 \\
\hline Bossier & 12,00 & 10,00 & 9,00 & 10,00 & 10,25 \\
\hline Médiab & $16,57 a$ & $16,07 a$ & $15,57 \mathrm{a}$ & $16,50 a$ & \\
\hline
\end{tabular}

a/ Média de 3 repetiçōes:

b/ Médias seguidas da mesma letra não diferiram significativamente entre si pelo teste Tukey ao nível de 5\% de probabilidade. 
144.

APENDICE 7 - Peso de 100 sementes (g) de quatorze cultivares de so ja em quatro épocas de semeadura, no Estado de Goiăs, ano agrícola 1981/82.

\begin{tabular}{|c|c|c|c|c|c|}
\hline \multirow{2}{*}{ CULTIVARES } & \multicolumn{4}{|c|}{ EPOCAS DE SEMEADURA - a] } & \multirow{2}{*}{ MEDIA } \\
\hline & 21/out. & 30/out. & 09/nov. & 19/nov. & \\
\hline Bossier & 164 & 178 & 167 & 154 & $166 a$ \\
\hline IAC- 8 & 177 & 172 & 162 & 155 & $166 a$ \\
\hline Doko & 170 & 165 & 163 & 164 & $165 a$ \\
\hline Paranagoiana & 155 & 168 & 164 & 168 & $164 \mathrm{ab}$ \\
\hline Paranā & 151 & 166 & 152 & 151 & $155 \mathrm{bc}$ \\
\hline Santa Rosa & 161 & 153 & 157 & 151 & 155 bc \\
\hline EMGOPA-301 & 151 & 160 & 156 & 149 & $154 \mathrm{bc}$ \\
\hline Tropical & 160 & 154 & 150 & 149 & $153 \mathrm{c}$ \\
\hline Numbaira & 141 & 169 & 148 & 140 & $149 \mathrm{c}$ \\
\hline IAC-6 & 167 & 145 & 148 & 131 & $148 \mathrm{~cd}$ \\
\hline IAC-2 & 137 & 139 & 138 & 140 & $138 \mathrm{de}$ \\
\hline UFV-1 & 131 & 135 & 128 & 132 & 131 \\
\hline Cristalina & 118 & 121 & 120 & 124 & 121 \\
\hline IAC-7 & 118 & 119 & 119 & 118 & 118 \\
\hline Médiab/ & $150 \mathrm{ab}$ & $153 a$ & $148 \mathrm{bc}$ & $145 c$ & \\
\hline
\end{tabular}

a/ Média de 3 repetiçōes.

b/ Médias seguidas da mesma letra não diferiram significativamente entre si pelo teste Tukey ao nível de 5\% de probabilidade. 